\title{
Energy Use in Petroleum Refineries
}

\author{
V. O. Haynes
}

\section{OAK RIDGE NATIONAL LABORATORY}




\section{DISCLAIMER}

This report was prepared as an account of work sponsored by an agency of the United States Government. Neither the United States Government nor any agency Thereof, nor any of their employees, makes any warranty, express or implied, or assumes any legal liability or responsibility for the accuracy, completeness, or usefulness of any information, apparatus, product, or process disclosed, or represents that its use would not infringe privately owned rights. Reference herein to any specific commercial product, process, or service by trade name, trademark, manufacturer, or otherwise does not necessarily constitute or imply its endorsement, recommendation, or favoring by the United States Government or any agency thereof. The views and opinions of authors expressed herein do not necessarily state or reflect those of the United States Government or any agency thereof. 


\section{DISCLAIMER}

Portions of this document may be illegible in electronic image products. Images are produced from the best available original document. 
Printed in the United States of America. Available from National Technical Information Service

IJ.S. Department of Commerce

5285 Port Royal Road, Springfield, Virginia 22161

Price: Printed Copy $\$ 6.00$; Microfiche $\$ 2.25$

This report was prepared as an account of work sponsored by the United States Government. Neither the United States nor the Energy Research and Development Administration/United States Nuclear Regulatory Commission, nor any of their employees, nor any of their contractors, subcontractors, or their employees, makes any warranty, express or implied, or assumes any legal liability or responsibility for the accuracy, completeness or usefulness of any information, apparatus, product or process disclosed, or represents that its use would not infringe privately owned rights. 
ORNL/TM-5433

Contract No. W-7405-eng-26

ENERGY DIVISION

ENERGY USE IN PETROLEUM REFINERIES

V. 0. Haynes

Work supported by the U.S. Atomic Energy Commission

SEPTEMBER 1976

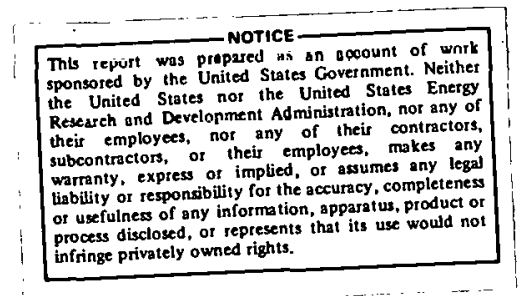

OAK RIDGE NATIONAL LABORATORY

Oak Ridge, Tennessee 37830

operated by

UNION CARBIDE CORPORATION

for the
ENERGY RESEARCH AND DEVELOPMENT ADMINISTRATION 
THIS PAGE

\section{WAS INTENTIONALLY \\ LEFT BLANK}


ENERGY USE IN PETROLEUM REFINERIES

Page

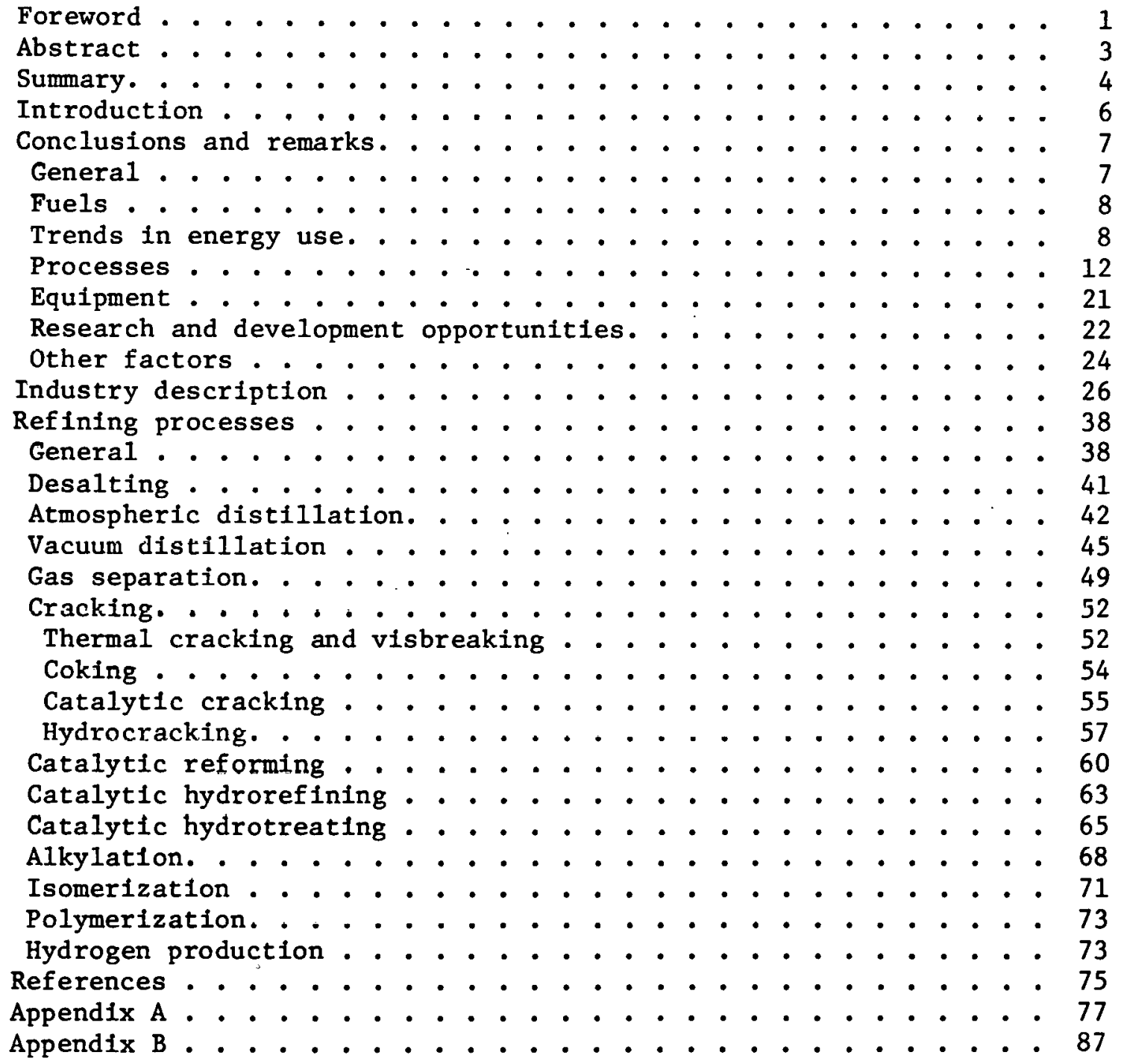


FOREWORD

The information contained in this report was obtained primarily from open-literature sources, supplemented by discussions with authors and by information obtained from a few representatives of the petroleumrefining industry. Although it was not possible in this limited effort to quantify precisely the energy used in refining petroleum, the information is believed to be sufficiently representative to support the conclusions. Detailed descriptions of the various petroleum-refining processes are well documented in several publications; thus, this report describes the processes only to the extent felt necessary to make them relevant to their energy requirements.

Appreciation is hereby expressed to D. C. Azbill, Shell Oil Company; R. W. Wendes, Amoco Oil Company; R. B. James, Universal Oil Products; and several of their associates for detailed information on some specific processes and for general discussions. However, the information contained in this report should not be construed to be representative of these sources. Appreciation is also expressed to those who offered many helpful comments after reviewing a draft of the report: $R$. W. Wendes, Amoco Uil Company; U. L. Culberson, Unlverslty of Témiessee;

J. H. Smithson, U. S. Energy Research and Development Administration; and R. S. Carlsmith and S. A. Reed, Oak Ridge National Laboratory. In view of the present accepted practice in this country for the petroleum refining industry, common U. S. units of measurement have been used throughout this publication. In recognition of the position of the U.S. as a signatory to the General Conference on Weights and Measures, which gave official status to the metric 
SI system of units in 1960, appropriate conversion factors have been provided as follows:

TO CONVERT

Btu

kWhr

barrels (bb1)

$f t^{3}$

$\mathrm{Btu} / \mathrm{bbl}$ joule

joule

$\mathrm{m}^{3}$

$m^{3}$

joules $/ \mathrm{m}^{3}$
MULTIPLY BY

$1.055 \times 10^{3}$

$3.600 \times 10^{6}$

$1.590 \times 10^{-1}$

$2.832 \times 10^{-2}$

$6.635 \times 10^{3}$ 


\section{ABSTRACT}

Refining petroleum accounts for about $4 \%$ of the total energy consumed in the United States and about $15 \%$ of all industrial consumption. The kinds of energy used and the manner in which energy is used are discussed on a process-by-process basis. Emphasis is placed on existing processes to identify and quantify process and equipment substitutions which might significantly conserve energy.

General industry and process information is given and estimates of potential savings are made. A few research and development opportunities are identified and nontechnical factors are discussed. Nearly one-half the energy consumed by refineries is obtained from by-product refinery gas and coke, and about one-third is supplied by natural gas. On a regional basis, refineries were found to vary by a factor of two in the amount of energy used to refine a unit of crude oil. Refineries in regions traditionally abundant in inexpensive natural gas were found to use relatively more natural gas and energy. About $36 \%$ of the energy used by petroleum refineries is consumed in the distillation units to separate the refinery streams into their basic components. Including energy for manufacturing hydrogen, about $24 \%$ of the total is used for cracking of the heavier components. Most of the remainder is used for reforming, hydrogen treating, and alkylation, distributed about 11,17 , and $6 \%$ respectively. Potential energy savings discussed in this report total $61 \times 10^{13}$ Btu/yr based on 1974 capacities, a figure which represents about $20 \%$ of the energy consumed to refine petroleum. 
SUMMARY

Petroleum refineries use slightly over $3 \times 10^{15}$ Btu of energy annually - about $4 \%$ of yearly U.S. energy consumption. Plant size, product, and location affect refinery energy consumption. Processing has become more complex as plant size has increased, requiring more energy per unit output. Refineries in Texas and along the Gulf Coast use considerably more energy than the national average because their design was based on a relatively mild climate and inexpensive natural gas.

A little over half of the energy used to refine petroleum comes from refining streams - refinery gas, oil, liquified petroleum gas (LPG), and coke. The average energy required per unit output has declined about $0.8 \%$ /year since 1960 to a 1974 value of $707,000 \mathrm{Btu} / \mathrm{bbl}$ crude, but there are large regional variations in both the trend and the consumption. The increasing price of fuel will lead to more effective use of energy. However, because the growth of capacity is anticipated to be slow, conservation will have to be achieved by retrofitting existing plants and as a result will be more expensive and less effective.

The fuel-, steam-, and electricity-energy requirements, energy quality, and energy savings are estimated for most of the refining processes. Processes most Important relative to energy consumption arc distillation, thermal cracking, hydrocracking, hydrotreating, reforming, and alkylation. It appears that about $20 \%$ of the energy used to refine petroleum could be saved by the following measures: 


\section{Conservation measure}

Savings

$\left(10^{13}\right.$ Btu/year $)$

Adding distillation trays and reducing refluxing, operating with high tray flooding, and refining to

minimum product quality

Use of more energy-efficient fluid catalytic crackers

Use of cyclic, bimetallic-catalyst reformers instead

of semiregenerative units

5.0

Hydrotreating with no makeup hydrogen when possible

1.2

Use of hydrofluoric acid (HF) alkylation when analyses indicate it is more energy-efficlent

0.6

Improved furnace design, furnace control, and furnace

heat recovery

and exchanging to a lower temperature

Use of back-pressure turbines instead of condensing

turbines for both direct drive and electricity generation 
Conservation measure

Use of turbo-expanders and hydraulic turbines when feasible

Use of more efficient pumps and motors and proper sizing

Other factors that affect energy consumption in petroleum refining and can thus be explored for their practicability in conserving energy are: availability and price of fuel; product specifications; industry standards for products, equipment, operation, and maintenance; quality of crude oil to be refined; and integration of refineries with electric utilities and other industries.

\section{INTRODUCTION}

Historically, energy has been sufficiently cheap and abundant in the Untted States that minimizing energy requirements rarely has been a decisive factor in minimizing product cost. This observation is particularly true of the petroleum-refining industry in the Gulf Coast region where inexpensive gas has been readily available and was a significant influence in locating refineries in this region. The economics of energy have changed drastically in recent times and the adequacy of our energy supply has become a national concern. This report was prepared under the sponsorship of the U. S. Atomic Energy Commission to provide detailed information on the types, end-uses, and 
respective quantities of energy consumed in major U. S. industries. Specific objectives of this study are to:

1. Characterize the petroleum-refining industry by plant size, by products, and by location, including historical data.

2. Describe the extent of energy consumption and the kinds of fuels used.

3. Discuss current, planned, and proposed energy conservation practices, identify process choices which affect energy consumption, and identify opportunities for using alternate fuels.

4. Identify areas of research and development having potential for conserving energy.

\section{CONCLUSIONS AND REMARKS}

\section{General}

Petroleum refineries use slightly over $3 \times 10^{15}$ Btu of energy per year, a figure which represents about $4 \%$ of annual $U$. S. energy consumption and about $15 \%$ of annual industrial energy consumption. Although little of the refinery fuel is oil, energy consumption often is related to the equivalent amount of crude oil that would be required; expressed as such, refinery fuel consumption represents about $12 \%$ of the crude oil input to refineries.

Petroleum-refining-industry characteristics of plant size, product, and location all affect energy consumption. Size studies reveal that refining capacity is being concentrated in increasingly larger plants. As capacity has increased and the number of refineries has decreased, 
average plant size in the past decade increased about $60 \% .^{1}$ Larger plants characteristically involve more complex refining processes, requiring more energy per unit of crude oil. However, this cost is not necessarily undesirable since the increased quality of the product might justify the increased energy consumption (e.g., clear, low-sulfur fuels; clear, high-octane gasoline; petrochemical feedstock).

From a location consideration, a large fraction of the petroleum refineries are located in the Texas and Gulf Coast regions where inexpensive supplies of natural gas have made it uneconomical to practice rigorous energy conservation. As shown by F1g. 1, energy consumption for the Texas refineries (districts 7 and 8 ) is substantially above the national average, with a wide variation of energy consumption among the districts. Because $26 \%$ of the total crude oil is processed in the two Texas districts, their refineries would save $23 \times 10^{13}$ Btu of energy per year if consumption were reduced to the national average.

\section{Fuels}

Fuels are used almost exclusively tor procēs̄s heating and sceam production. Steam is used as a stripping agent, in vacuum jets, in heat exchangers, and in powering turbines and pumps. Slightly over half of the energy comes from refinery streams - distributed about $60 \%$ from refinery gas, $20 \%$ from oil and LPG, and 20\% from coke. About one-third of the energy is from natural gas. The electrical energy (four-fifths of which is purchased) is produced mainly from combustion of coal and natural gas and is used primarily for pumping.

$$
\text { Trends in Energy Use }
$$

The unit energy consumption for refining petroleum is subject to several competing demands - efforts to conserve energy, increased 
ORNL-OWG 76-5308

DASHED LINES ARE UNITED STATES AVERAGE UPPER LINES ARE PER BARREL CRUDE INPUT LOWER LINES ARE PER BARREL TOTAL INPUT
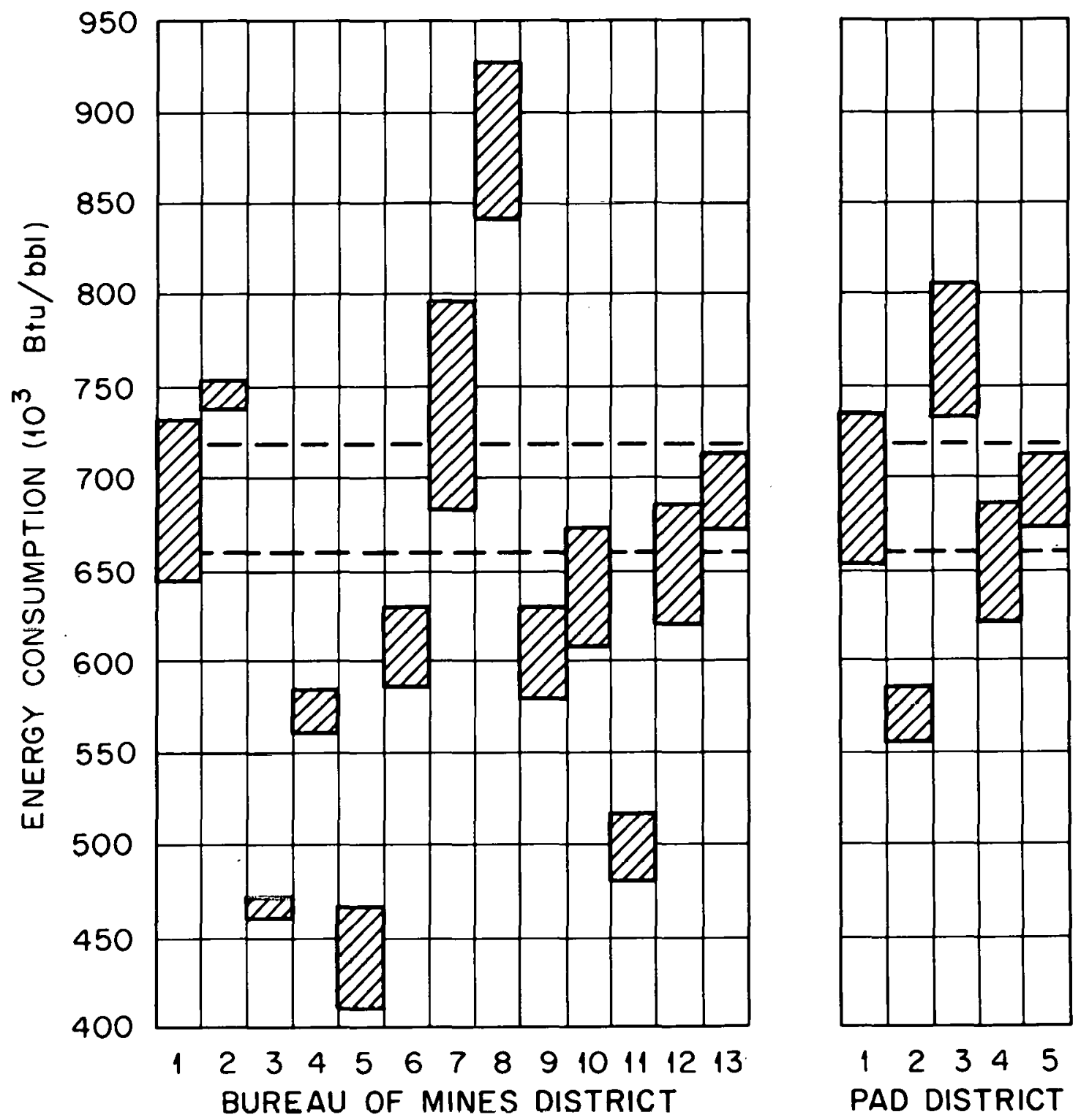

Fig. 1. Energy requirements for U.S. petroleum refineries by districts 1972 . 
refining, and environmental restraints on products and refinery emissions. The unit energy consumption has been decreasing slowly in recent years and involves much retrofitting of existing plants. It appears that retrofitting and replacement of existing equipment and improved plant operation and maintenance will continue to predominate conservation efforts. Thus the degree to which energy conservation can be effected will be substantially less than could be achieved by an industry dominated by new energy-conserving plants. Substitution of other fuels for natural gas can also be expected at existing refineries.

The fuels and relative amounts used to supply energy for refining petroleum changed only slightly between 1961 and 1974. Between 1962 and 1974 the U. S. average of energy required to refine a barrel of crude oil dropped from 790,000 to $707,000 \mathrm{Btu} / \mathrm{bb} 1$, an average decrease of only $0.8 \% /$ year. Several major oil refiners have formed task groups to conserve energy in their refineries. Although some claim to have cut fuel consumption by a few percent as early as 1971, values from the Bureau of Mines show very little change within the refinery industry between 1971 and 1974; the reported energy consumption per barrel was essentially constant for this period. A shifting use of fuels is apparent by the increasing use of fuel oil and coke to replace natural gas. Recent efforts to conserve energy, then, appear to be obscured by a significant and approximately equal increase in energy used for additional petroleum refining (to produce, for example, high-octane, unleaded gasoline and low-sulfur products) and/or protection of the environment. A trend also exists to reduce reliance on natural gas. Large variations both in the magnitude of energy consumed per barrel of 
oil refined and in recent fuel-use trends are found when comparing regional values, about half the regions showing increases and half showing decreases.

The increasing value of fuel undoubtedly will lead to more effective use of energy. According to historical values, though, the increasing emphasis on conservation of fuel for transportation and heating will retard expansion of the petroleum-refining industry, and capacity probably will be dominated by existing plants for many years. Thus, most conservation measures will necessarily be of the retrofitting type which are characteristically more expensive and less effective.

Refineries are in a unique position relative to the availability of fuel because their feed can be readily used to replace other fuels. The price, availability, and allocation of natural gas are of concern to refiners. Furthermore, there will be efforts to supply some energy with coal, possibly combusted in fluidized-bed units to minimize undesirable emissions. The energy from other low-grade waste materials also might be recovered in fluidized-bed combustion. Another long-range alternative under investigation is to use more efficiently the energy supplied by an electric-generating utility. In addition to electricity, for example, high-temperature process heat could be diverted through an appropriate heat-transfer system and supply steam which might furnish some of the petroleum-refining energy currently supplied from purchased fossil fuel, especially natural gas. If a joint venture were undertaken with an electric utility and other industries, it might even be possible to substitute nuclear fuel or coal for oil and gas. 
Processes.

The major petroleum refining processes and their representative requirements for fuel, steam, and electricity as discussed in this report are summarized in Table 1. Included is the energy required to refine a barrel of crude oil based on the feed to each process as a percentage of the crude oil input. The total energy, estimated to be $379,000 \mathrm{Btu} / \mathrm{bbl}$ of crude oil, includes energy for manufacturing hydrogen (a credit for the hydrogen produced by the reforming process). Not included in the total is energy for lubricating oil, wax, and asphalt processing, a contribution which might raise the total energy estimate to $455,000 \mathrm{Btu} / \mathrm{bbl}$ of crude oil. Other energy uses not included are those for catalyst and additive manufacture, product blending and storage, treatment of water and wastes, and terminal operations. The estimated unit energy usage is much below the U. S. average reported by the Bureau of Mines and about the same as values reported for $U$. S. districts with lowest consumption, suggesting that the estimated given here may be optimistically low relative to actual energy use. Keasons for major differences between estimates in this study and those of some other studies include the much lower energy requirements in this study for catalytic cracking and alkylation and a credit assignment for hydrogen produced by the reforming process. These factors together could account for about $190,000 \mathrm{Btu} / \mathrm{bbl}$ of crude ofl, distributéd 110,000, 25,000 , and $55,000 \mathrm{Btu} / \mathrm{bbl}$ for catalytic cracking, alkylation, and reforming respectively. The efficiency of heat recovery from the regeneration of the catalyst in the catalytic cracking process is iikely to be the main reason for variations in the reported values. 
Table 1. Energy requirements for petroleum-refining processes

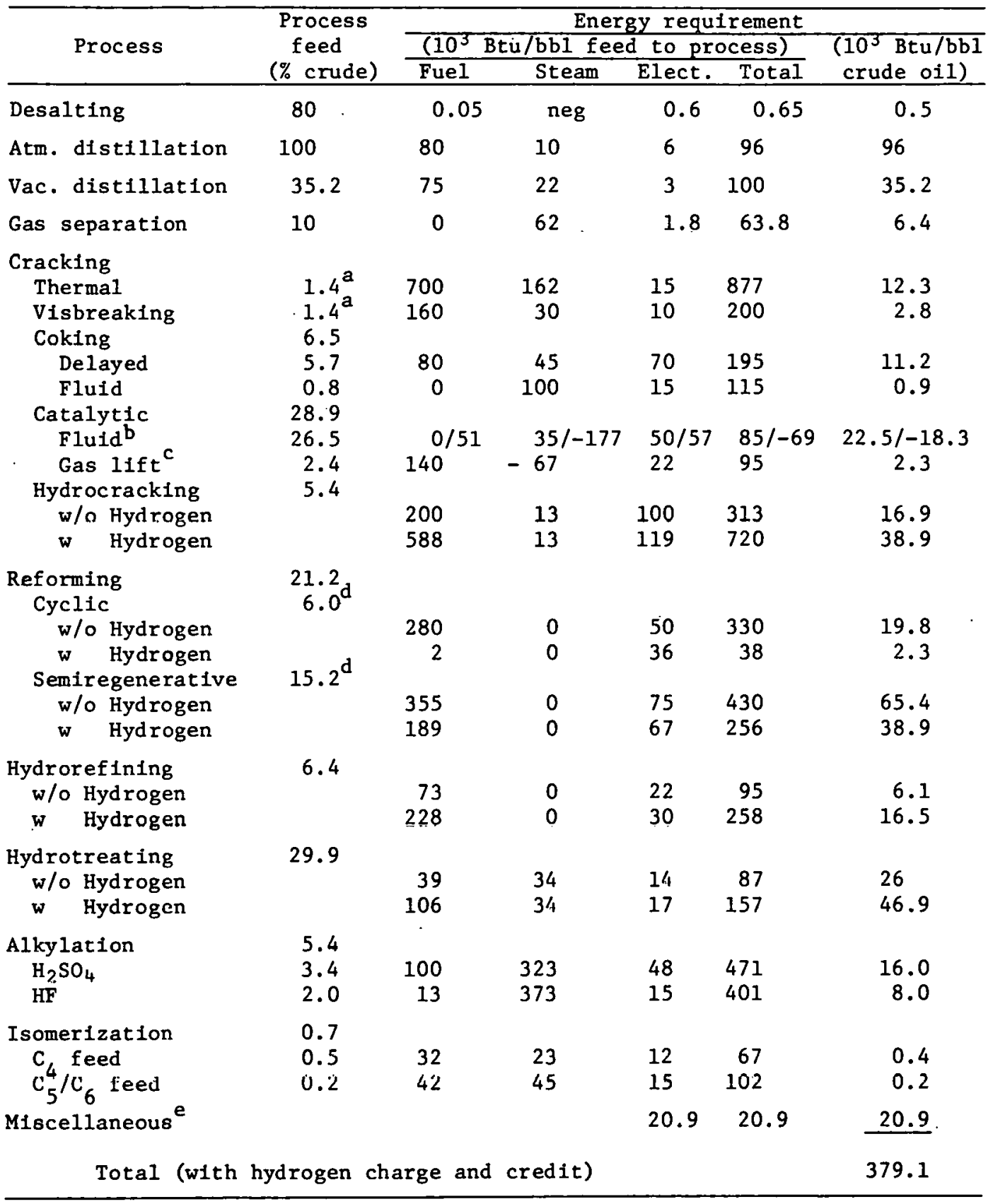

${ }^{a} 0.1$ added to account for "other."

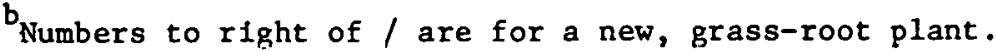

C Includes 0.4 of Houdriflow.

$\mathrm{d}_{0.3}$ added to account for "other."

elighting, shops, etc. from: W. L. Nelson, Guide to Refining Costs, 2nd ed., The Petroleum Publishing Company, Tulsa, Okla. (1970), p. 158. 
Table 2 gives the energy requirements per barrel of crude oil refined, separated according to temperature, for U. S. average process capacities. From steam requirements shown and assuming steam is generated at $750 \mathrm{psi}$ and $566^{\circ} \mathrm{C}\left(1050^{\circ} \mathrm{F}\right)$, it is estimated that energy equivalent to $3 \mathrm{kWh}$ could be developed per barrel of crude oil for direct drive of large compressors and pumps or for electric generation. That is, at a high fuel utilization energy could be generated by letting steam down to the process requirements through back-pressure turbines. This contribution would represent about $40 \%$ of the refinery's electricity needs and is about twice the average amount of electricity generated onsite, some of which is generated by low-efficiency condensing steam turbines and by gas turbines. The estimate of $3 \mathrm{kWhr}$ should not be considered an upper limit of electricity generation at a high fuel utilization for several reasons:

1. Summing up what might be possible at each refinery might vary substantially from this average estimate.

2. Steam could be generated at higher temperatures and pressures, making more electrical energy available for a given processheat requirement. This increased generation of ten would require new equipment,

3. Some of the lower-temperature-process-heat requirements could be served with steam. However, the merit of substituting steam for a low-temperature-process-heat requirement would be questionable since fuel utilization would be only slightly improved or even lowered. 
Table 2. Energy quality for petroleum-refining processes

\begin{tabular}{|c|c|c|c|c|c|c|c|}
\hline \multirow{3}{*}{ Process } & \multicolumn{7}{|c|}{ Energy $\left(10^{3}\right.$ Btu/bb1 crude) } \\
\hline & \multicolumn{2}{|c|}{ Steam at: } & \multicolumn{3}{|c|}{ Fuel for process temperature of: } & \multirow[b]{2}{*}{ Electricity } & \multirow[b]{2}{*}{ Total } \\
\hline & $500^{\circ} \mathrm{F}$ & $750^{\circ} \mathrm{F}$ & $650-750^{\circ} \mathrm{F}$ & $750-1000^{\circ} \mathrm{F}$ & $1650^{\circ} \mathrm{F}$ & & \\
\hline Desalting & & & 0.04 & & & 0.5 & 0.5 \\
\hline Atm. distillation & 13 & & 80 & & & 6.0 & 96 \\
\hline Vac. distillation & 7.7 & & & 26.4 & & 1.1 & 35.2 \\
\hline Gas separation & 3.1 & & 3.1 & & & 0.2 & 6.4 \\
\hline Thermal cracking & 2.3 & & & 9.8 & & 0.2 & 12.3 \\
\hline Visbreaking & 0.4 & & & 2.2 & & 0.1 & 2.7 \\
\hline $\begin{array}{l}\text { Cok1ng } \\
\text { Delayed } \\
\text { Fluid }\end{array}$ & 0.8 & 2.6 & & 4.6 & & $\begin{array}{l}4.0 \\
0.1\end{array}$ & $\begin{array}{r}11.2 \\
0.9\end{array}$ \\
\hline $\begin{array}{l}\text { Catalytic cracking } \\
\text { FCC } \\
\text { Gas-1ift }\end{array}$ & $\begin{array}{r}9.3 \\
-1.6\end{array}$ & & & 3.4 & & $\begin{array}{r}13.2 \\
0.5\end{array}$ & $\begin{array}{r}22.5 \\
2.3\end{array}$ \\
\hline Hydrocracking & 0.7 & & & 10.8 & & 5.4 & 16.9 \\
\hline $\begin{array}{l}\text { Reforming } \\
\text { Cyclic } \\
\text { Semiregenerative }\end{array}$ & & & & $\begin{array}{l}16.8 \\
54.0\end{array}$ & & $\begin{array}{r}3.0 \\
11.4\end{array}$ & $\begin{array}{l}19.8 \\
65.4\end{array}$ \\
\hline Hydrorefining & & & 4.7 & & & 1.4 & 6.1 \\
\hline Hydrotreating & 10.2 & & 11.6 & & & 4.2 & 26.0 \\
\hline $\begin{array}{l}\text { Alkylation } \\
\mathrm{H}_{2} \mathrm{SO}_{4} \\
\mathrm{HF}\end{array}$ & 7.5 & 11.0 & $\begin{array}{l}3.4 \\
0.3\end{array}$ & & & $\begin{array}{l}1.6 \\
0.3\end{array}$ & $\begin{array}{r}16.0 \\
8.1\end{array}$ \\
\hline $\begin{array}{l}\text { Isomertzation } \\
c_{4} \text { feed } \\
c_{5}^{4} / c_{6} \text { feed }\end{array}$ & $\begin{array}{l}0.1 \\
0.1\end{array}$ & & $\begin{array}{l}0.2 \\
0.1\end{array}$ & & & $\begin{array}{l}0.06 \\
0.03\end{array}$ & $\begin{array}{l}0.4 \\
0.2\end{array}$ \\
\hline Hyd rogen & & & & & 9.0 & 0.4 & 9.4 \\
\hline Miscellaneous & & & & & & 20.9 & 20.9 \\
\hline Total & 50.6 & 13.6 & 103.4 & 128 & 9.0 & 74.6 & 379.2 \\
\hline
\end{tabular}


4. Gas turbines utilizing waste exhaust heat can be used to generate electricity.

5. Additional use of 150-psi steam can be achieved by substituting it for some direct heating.

Aside from these considerations, the practicability of onsite electrical generation depends also on factors such as capital costs and reliability of the electrical supply.

The most energy-intensive petroleum refining processes are thermal cracking, hydrocracking, reforming, alkylation, and polymerization. However, based on extent of use, the less energy-intensive processes of distillation and hydrotreating also are relatively important energy consumers while polymerization is relatively unimportant. The distribution of energy consumption among the various processes is shown in Figure 2 .

Table 3, based on 1974 capacities and processing rates, summarizes some of the potential for saving energy discussed in this report. Total savings equal $61 \times 10^{13} \mathrm{Btu} /$ year, about $19.7 \%$ of the energy used to refine petroleum.

It appears that a superior process to replace distillation does not exist, but there undoubtedly are variations of the process which can reduce energy consumption, such as adding trays combined with reduced rcfluxing, opcrating with high tray flooding, and cvaluating product quality to reduce "overrefining." If $5 \%$ of the process heat used in the. distillation-gas separation units could be saved (about $5800 \mathrm{Btu} / \mathrm{bb} 1$ of crude oil), refining petroleum would require $3.2 \times 10^{13}$ fewer Btu per year. 
ORNL-DWG $76-5282$

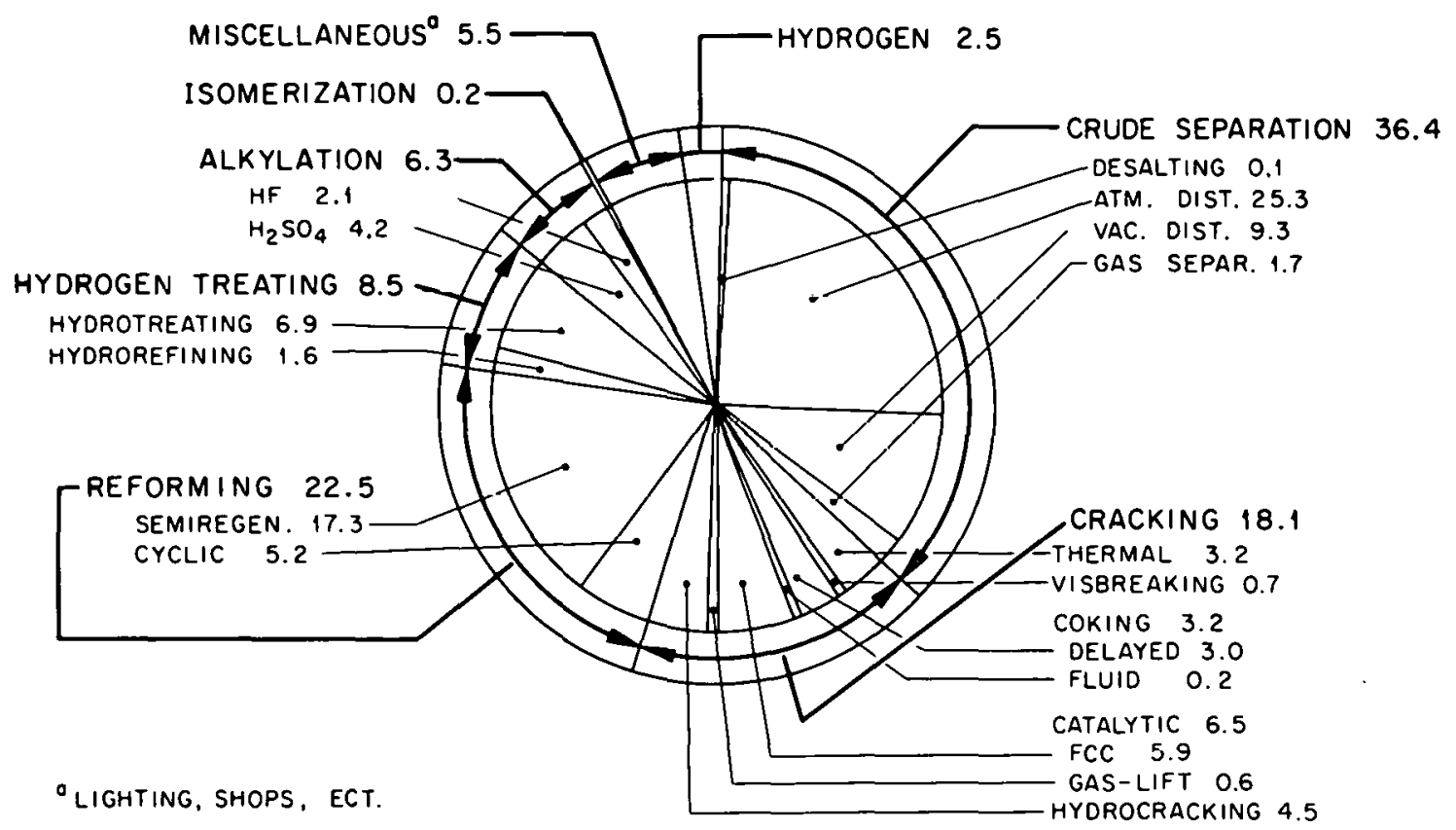

(0) ENERGY DISTRIBUTION AMONG PROCESSES

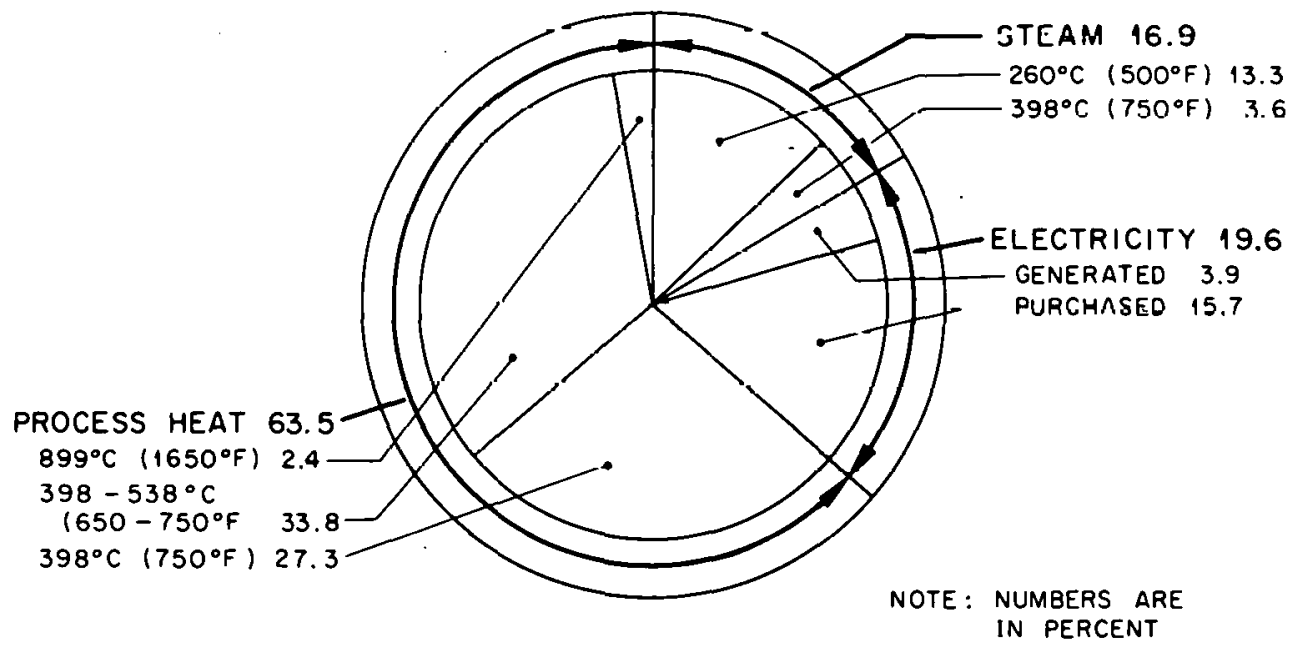

(b) DISTRIBUTION AMONG TYPES OF ENERGY

Fig. 2. Distribution of energy in percent for petroleum processes and for types of energy used. 
Table 3. Potential annual energy savings for petroleum refining ${ }^{a}$

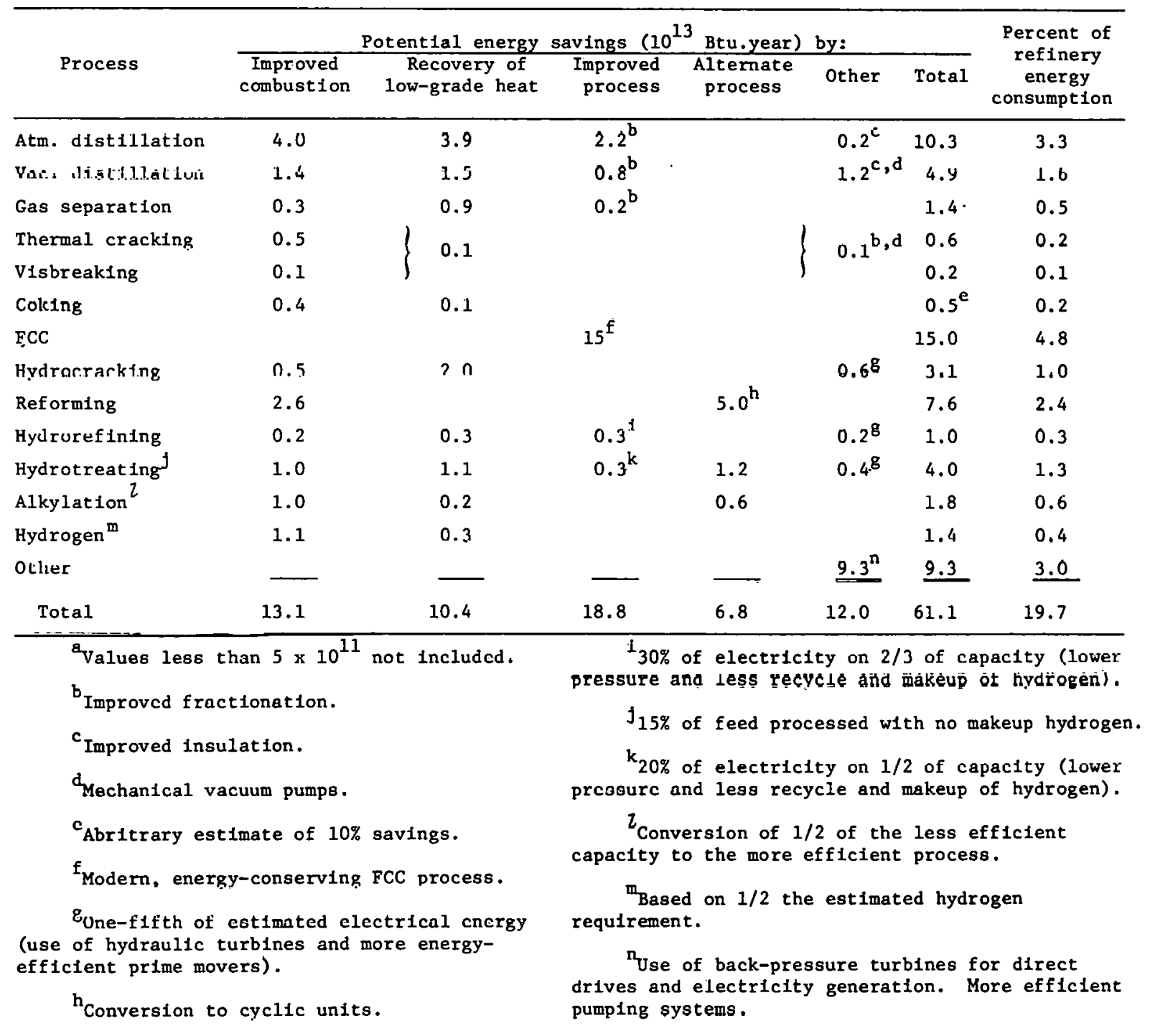


The cracking process uses considerable energy but most of the thermal cracking units have been replaced by fluid catalytic cracking units (FCCU) which recover energy produced by the burning of coke (in the regenerators) deposited on the catalyst. By generating steam in carbon monoxide (CO) boilers and perhaps recovering energy with turboexpanders, FCCUs become low energy consumers and perhaps even net energy generators. Cracking in the FCCU is desirable because the units conserve energy relative to thermal cracking units which, except for coking units, appear to be phasing out. Although gas-lift catalytic crackers use about $12 \%$ more energy than do the fluid-bed types, there is such a small capacity of gas-1ift units that estimated savings from replacing them with fluid-bed units total only $10^{12} \mathrm{Btu} /$ year. By comparison, highly efficient FCCU is estimated to create potential savings of $15 \times 10^{13} \mathrm{Btu} /$ year.

The reforming process using a bimetallic catalyst appears to be quite advantageous because it allows operation at lower temperatures and pressures, Increases yields, and extends the process operating period. Semiregenerative units operate at higher pressures and higher hydrogen-tooil ratios than do cyclic-type units in order to minimize carbon deposition on the catalyst, and thus require more compressor energy and charge heat and generate less hydrogen. For these reasons conversion to the more energy-efficient cyclic process would conserve energy. Assuming that half the units use bimetallic catalysts and the savings would be only half the differential energy consumption, and accounting for energy required for hydrogen manufacture, the potential savings is about $5 \times 10^{13} \mathrm{Btu} /$ year. 
Hydrotreating and hydrorefining requirements vary widely and are difficult to access because of the wide variety of feeds. Hydrogen requirements are significant and the energy used to provide the hydrogen is about equal to other process-energy requirements. One hydrotreating process requires no makeup hydrogen and thus uses about $40 \%$ less energy; however, it is restricted to refining those feeds that will generate sufficient hydrogen for the hydrogen-treating reactions. It has not been established how much of the feed being hydrotreated could be treated by this process, but if a portion of $15 \%$ were used, and energy to manufacture hydrogen is taken 1nto account, the energy savings is estimated to be $1.2 \times 10^{13} \mathrm{Btu} /$ year.

In alkylation processes sulfuric acid $\left(\mathrm{H}_{2} \mathrm{SO}_{4}\right)$ is used twice as frequently as hydrofluoric acid (HF) as the catalyzing agent. One reference indicates that the $\mathrm{H}_{2} \mathrm{SO}_{4}$ process uses about $14 \%$ less energy than the HF process, but liscensors of the HF process claim the HF process uses less energy. Because fractionation equipment is essentially the same for both processes, HF process substitution would consist primarily of modifying or replacing the reactor section. Based on the liscensor information, conversion of half the $1974 \mathrm{H}_{2} \mathrm{SO}_{4}$ capacity to $\mathrm{HF}$ units would save about $0.6 \times 10^{13} \mathrm{Btu} / \mathrm{year}$.

Isomerization is not highly energy-intensive and has such little capacity that it is insignificant in energy conservation studies. Polymerization, although energy-intensive, is not widely used and therefore insignificant relative to energy conservation because it is less than half as efficient as alkylation in producing gasoline from olefin feed and because the alkylation product is more compatible with modern engines. 
Equipment

There are many opportunities for decreasing energy consumption in petroleum refineries by adding or changing equipment. The major areas for effecting energy conservation are associated with the furnaces and product-cooling equipment. Other conservation benefits would result from reducing heat losses from equipment and making effictent use of steam.

Furnace design, furnace control, and greater heat recovery from furnaces are areas where conservation could result in a potential for substantial energy savings. If the overall efficiency of two-thirds of the furnace units were improved from 75 to $88 \%$ by such means as recovery of energy from flue gas, optimizing excess air, and decreasing convectionradiation losses, fuel consumption would be reduced $10 \%$ - a savings of about $13 \times 10^{13}$ Btu/year.

Despite the extensive use of heat exchange in refineries, a large fraction of the heat is rejected in air- and water-cooled heat exchangers. Thus further utilization of heat exchange between process streams or for other heating requirements, especially using the rejected lowremperature heat, warrants further attention. Recovery of one-fourth of the heat energy in cooling streams would result in an estimated energy savings of $10 \times 10^{13} \mathrm{Btu} /$ year.

Producing vacuum with mechanical pumps rather than with steam-jet ejectors has the potential for reducing related energy requirements by 75 to $90 \%$, saving about $1.1 \times 10^{13} \mathrm{Btu} /$ year.

As previously discussed use of back-pressure turbines in lieu of inefficient condensing turbines has the potential for saving at least $4.7 \times 10^{13}$ Btu/year. 
Recovering energy from high-pressure process streams by letting the pressure down through turboexpanders or hydraulic turbines is applicable whenever the process streams are being reduced at pressure ratios greater than a value of about 2. This practice could save over half of the energy required to provide the high-pressure stream and is applicable to fluid catalytic cracking, hydrocracking, some reforming, hydrorefining, and hydrotreating processes. The estimated savings, assuming application to one-third of the 1974 hydrocracking, hydrorefining, and hydrotreating capacities, is about $1.2 \times 10^{13} \mathrm{Btu} /$ year.

Pumps and motors account for 10 to $15 \%$ of refinery energy consumption. Thus a $10 \%$ improvement in the efficiency of pumping systems would save about $4.6 \times 10^{13} \mathrm{Btu} /$ year.

These equipment-related conservation practices represent a potential energy savings to the refinery industry of about $11 \%$. Other small energyconserving items would include the use of energy-efficient air-cooling towers in place of water cooling, more sophisticated instrumentation and control equipment, generation of electricity with turbines that exhaust at process-steam conditions, and more insulation.

Research and Development Opportunities

Some research and development needs related to petroleum refineries are: further determination of the effect of process parameters on energy consumption in the production of an equivalent or suitable product; development of reliable, instrumented systems to measure important process characteristics and control the processes at optimum conditions; development of improved catalysts; improvement in overall fuel utilization by considering both the efficiency of internal-combustion engines and 
the petroleum refining necessary to produce fuel for the engine; and development of equipment and techniques for the beneficial use of lowgrade heat.

Improving the efficiency and reliability of existing processes and equipment, based on economic trade-offs involving capital and fuel costs, is a continuing effort in the refinery industries. Generalized effects of process parameters on energy use are well documented; however, because selecting and controlling the oil-refining process relates to the economic position among competitors, it is doubtful that there does or should exist free exchange of the "fine" effects of process variables. The only obvious ways to stimulate more efficient processes and equipment are through high fuel costs and creation of an energy-conscious as well as economic climate to encourage refiners to emphasize energy efficiency in optimizing process variables and in monitoring and controlling equipment. Catalysts, used in nearly all refining processes, are related to about two-thrids of oil-refining energy consumption because of their influence on process temperatures, pressures, recycle rates, and product yields. Although current refining processes largely capitalize on the beneficial usee of catalyoto, oome limited in supply, significant basic catalyst research and development should continue.

Improving the octane rating of gasoline requires considerable energy. Thus analytical studies could be made in which optimized internalcombustion-engine performance as a function of octane rating is balanced with refinery-energy requirements to optimize overall utilization of the fuel. Several similar studies could consider the effect on gasoline quality of various amounts and kinds of antiknock additives. A confirmatory experimental program might also be required. 
A fertile area for research and development for many industries besides petroleum refineries is beneficial use of low-grade heat [e.g., less than $149^{\circ} \mathrm{C}\left(300^{\circ} \mathrm{F}\right)$ ] currently being rejected to the environment through air- and water-cooled heat exchangers. For refineries the amount of reject heat appears to equal at least one-fourth of the energy used to refine the petroleum and thus would represent about $10^{15}$ Btu/year. Some general areas of research are: inexpensive, efficient heat exchangers; use of absorption refrígeration systems; and low-temperature power generation cycles.

\section{Other Factors}

Several other significant factors which affect the energy used to refine petroleum include: the availability of fuel and its price; product specifications; industry standards for products, equipment, operation, and maintenance; quality of crude oil to be refined; and integration of refineries with electric utilities and other industries.

Fuel availability (including allocation) would become a factor of concern to ofl refineries primarily in the event of a scarcity of natural gas when other users of natural gas probably would be given a higher priority. Because U. S. refineries use natural gas to supply about a third of their energy, a natural gas shortage would require major substitution of another energy resource and modification or replacement of existing equipment. Possible substitute fuels are refinery products (coke, fuel oils, and gas produced from crude oil), coal, and electricity which could be produced from nearly all resources including emerging ones like nuclear, solar, and geothermal. Increasing the value of fuel in general will motivate refiners to devote more effort to conserving energy. 
Changing the relative value or availability of particular fuels could have marked effects on relative consumption of the various resources. Thus, allocation and pricing of fuels can greatly influence petroleumrefinery consumption of particular fuels. Government control through allocation and pricing schemes probably will determine the fuels consumed to refine petroleum. However, a large portion of the energy used to refine petroleum is refinery stream material, and all additional energy for a refinery could be obtained from the feed. Careful consideration also should be given to the end result, relative to energy consumption, of forcing a substitution between fuels. For example, using electricity would result in a lower overall efficiency unless beneficial use were made of the heat rejected in generating the electricity. Coal systems are also likely to be less efficient than a natural-gas system.

Product specifications such as sulfur content, lead content, and octane rating should be examined in detail to determine areas of unnecessary refining.

Standards for equipment and for operation and maintenance should be examined and expanded where necessary to reflect energy-conserving considerations.

Processing heavy crude oil, compared to higher-quality crude oil, requires somewhat greater quantities of energy to produce a given product. The only alternative is, of course, to locate and develop supplies of better-quality crude oil; however, this solution would be only temporary because eventually it undoubtedly will be necessary to use crude oil of al1 qualities.

Integration of petroleum refineries with electric utilities and other industries under a buy-and-sell arrangement for steam and 
electricity is very desirable because much of the heat ordinarily wasted during electric generation could be used. Utilization of fuel would markedly improve and at the same time a highly reliable energy supply would be provided. In addition, a major substitution for oil and natural gas would be possible with other fuels like coal, nuclear, solar, and geothermal.

\section{INDUSTRY DESCRIPTION}

The petroleum-refining industry as considered here is defined by the Standard Industrial Classification Manual ${ }^{2}$ under Code SIC-291

as follows:

"Establishments primarily engaged in producing gasoline, kerosine, distillate fuel oils, residual fuel oils, lubricants, and other products, through straight distillation of crude oil, redistillation of unfinished petroleum derivatives, cracking, or other processes."

Although U. S. refinery capacity has increased steadily since 1932 , the number of refineries reached a peak in the late 1930s and has since decreased steadily. Figure 3 shows the year-by-year changes since 1930 based on refs. 1 and 3. Reference 1 data for January 1, 1974 show that the $247 \mathrm{U}$. S. refineries having a total capacity of $14 \times 10^{6} \mathrm{bbl} / \mathrm{day}$, vary in capacity from 300 to $445,000 \mathrm{bbl} /$ day. Bureau of Mines data ${ }^{4}$ include 17 additional small refineries considered operable and having a combined crude-oil-processing capacity of $80,000 \mathrm{bbl} / \mathrm{day}$, a negligible portion of industry capacity. In recent years capacity and input have increased in the range of 3 to $4 \%$ per year. Refinertes seldom shut down and much of the difference between production and full utilization of the plants is attributed to operating with less than maximum feed. Input in 1970-1971 was above 90\% of capacity; 1973-1974 input dropped slightly to about $87 \%$ of capacity. 


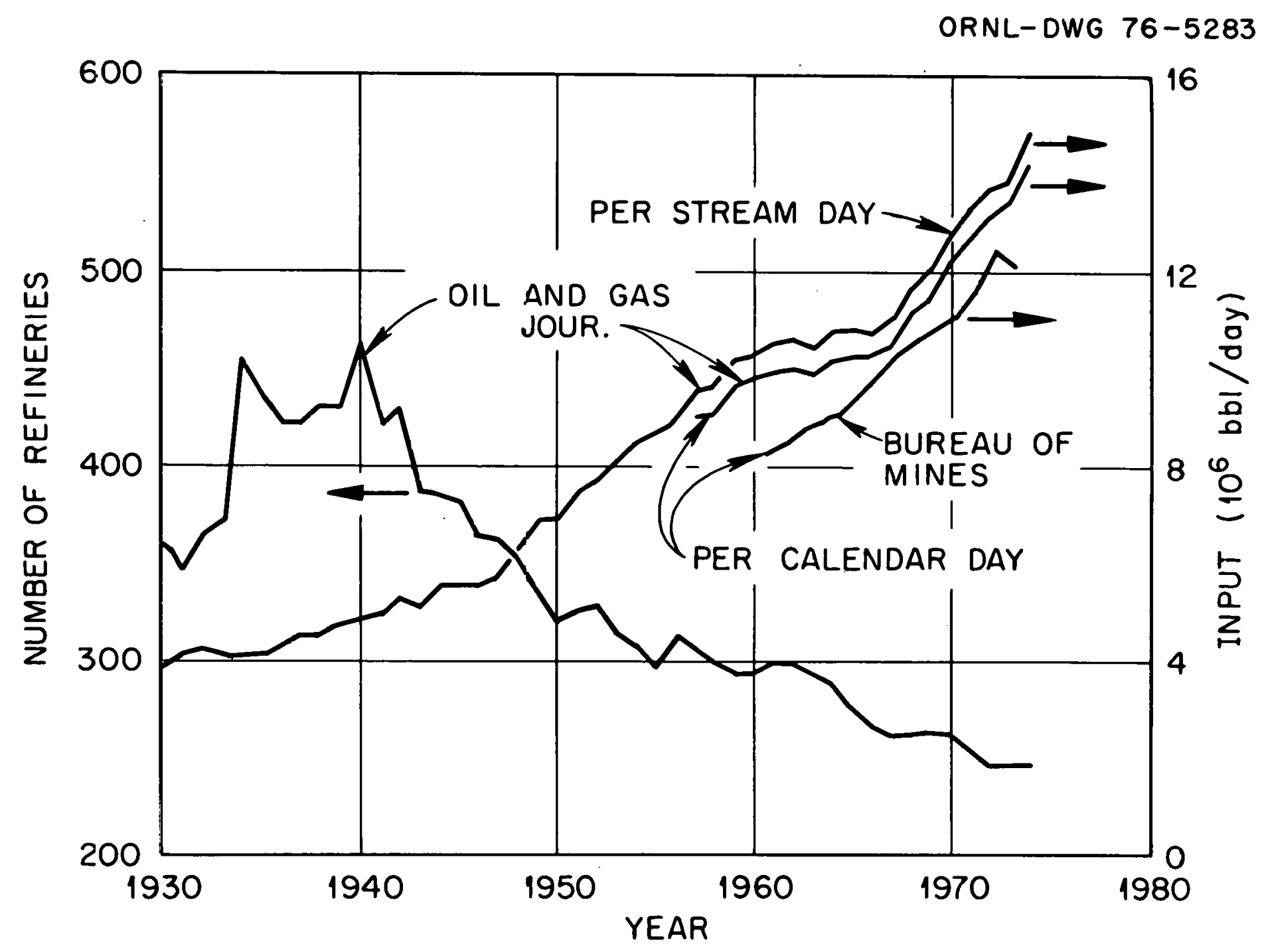

Fig. 3. U.S. refinery capacity and number since 1930. 
Although small refineries tend both to go out of business and to consolidate into larger refineries, there are still a large number of small refineries in the United States. Nearly half (47\%) of the nation's refineries have capacities less than $25,000 \mathrm{bbl} / \mathrm{day}$ and account for only $7 \%$ of total industry capacity. Forty percent have capacities less than $17,000 \mathrm{bbl} /$ day and account for $5 \%$ of total capacity. Similarly, $82 \%$ have capacities less than $100,000 \mathrm{bbl} / \mathrm{day}$ and account for $40 \%$ of total capacity. Thus $60 \%$ of the total U. S. refinery capacity is in $18 \%$ of the plants (capacities greater than $100,000 \mathrm{bbl} /$ day), $44 \%$ of capacity is in $10 \%$ of the plants (capacities greater than $150,000 \mathrm{bbl} / \mathrm{day}$ ) and $32 \%$ of capacity is in $6 \%$ of the plants (capacities greater than $200,000 \mathrm{bbl} /$ day) Figure 4 shows the size distribution of refinery capacity and refinery number based on the survey of ref. 1 .

About $80 \%$ of refinery capacity is located along the Gulf Coast, Great Lakes, West Coast, and East Coast - distributed 36, 18, 16, and 10\% respectively. Figure 5 shows the distribution of refinerles and capac1ry by both Petroleum Administration for Detense (YAV) districts and by Bureau of Mines ( $B$ of $M$ ) refining districts ${ }^{4}$ based on ref. 1 .

The petroleum-refining Industry has experlenced gradual but gross changes in its product stream. Kerosine, the major product of early refineries, was displaced by gasoline by 1915. Cracking, reforming, and alkylation processes have been developed to increase the quantity and octane rating of gasoline. Other less dramatic shifts in refinery procudts have occurred in response to demand for jet fuel, distillate fuel oil, residual fuel oil, lubes, asphalt, and petrochemical feedstocks. However, in recent years there have been no dramatic changes in the yield of refined petroleum products from crude oil. About half of the crude 

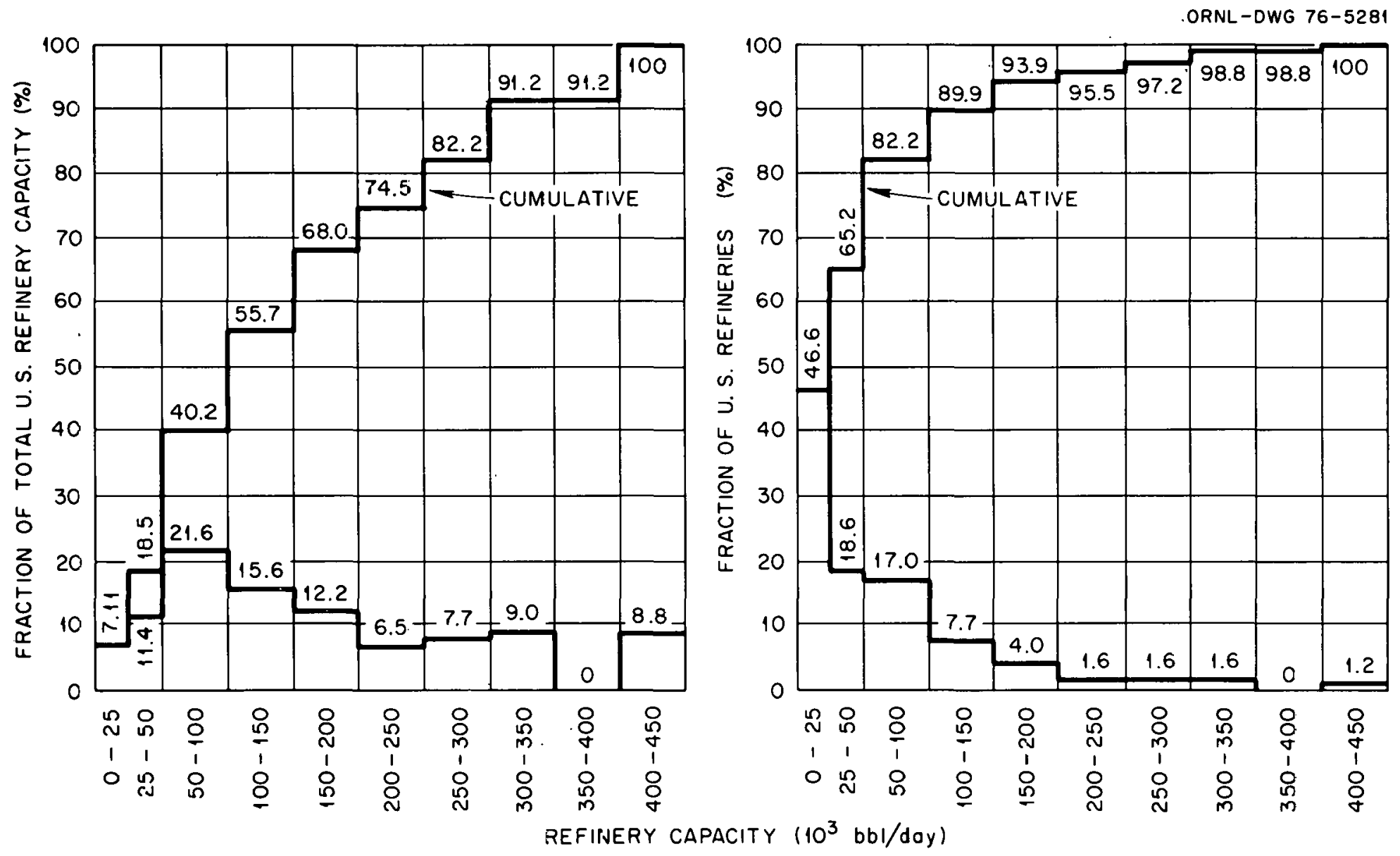

Fig. 4. Size distribution of U.S. petroleum refineries and refining capacity - January 1974. 
ORNL-DWG $76-5280$

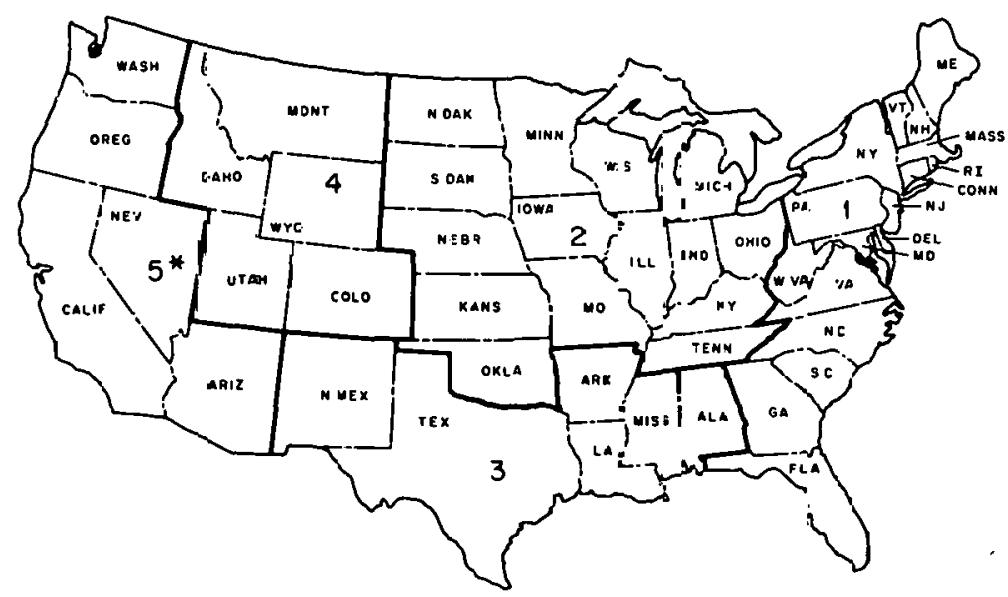

\begin{tabular}{|c|c|c|c|c|c|}
\hline \multirow[b]{2}{*}{ IISTAICT } & \multicolumn{2}{|c|}{ REFINERY } & \multicolumn{3}{|c|}{ REFINEAY CAPACITY- } \\
\hline & No. & (\% OF TOTAL & $\left(10^{3} \mathrm{~m}^{3} / \mathrm{dg}\right)$ & $\left(10^{3} \mathrm{bol} / \mathrm{day}\right)$ & $1 \%$ OF IND.) \\
\hline PAD 1 & 28 & 11.3 & 266 & 1672 & 11.8 \\
\hline & 66 & 26.7 & 816 & 3873 & 27.2 \\
\hline 3 & 77 & 31.2 & 928 & 5836 & 41.0 \\
\hline & 27 & 10.9 & 83 & 520 & 3.1 \\
\hline 5 & 49 & 19.9 & 368 & $\underline{2315}$ & 16.3 \\
\hline & 247 & & $\overline{2261}$ & $\overline{14216}$ & \\
\hline
\end{tabular}

(a) PETRCLEUM ADMINISTRATION FOR IDEFENSE (PADI OISTRICTS
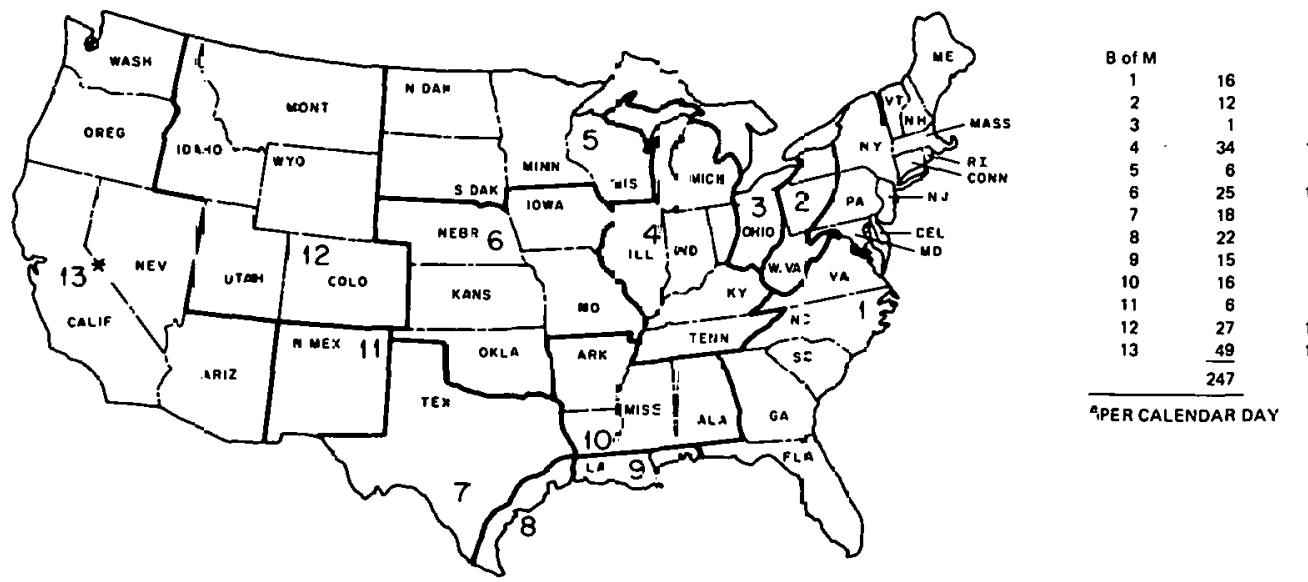

$\begin{array}{rr}6.5 & 23 \\ 4.9 & 32 \\ 0.4 & \\ 13.8 & 40.8 \\ 2.4 & 45 \\ 10.1 & 15 \\ 7.3 & 74 \\ 8.9 & 520 \\ 6.1 & 29 \\ 6.5 & 2 \\ 2.4 & \\ 10.9 & 83 \\ 19.8 & 36 \\ & \\ & 226\end{array}$

\begin{tabular}{|c|}
\hline 234 \\
\hline 9 \\
\hline $\begin{array}{r}404 \\
45\end{array}$ \\
\hline $\begin{array}{r}45 \\
158 \\
74\end{array}$ \\
\hline $\begin{array}{r}74 \\
520\end{array}$ \\
\hline $\begin{array}{r}297 \\
28\end{array}$ \\
\hline $\begin{array}{r}9 \\
83\end{array}$ \\
\hline$\frac{368}{2281}$ \\
\hline
\end{tabular}

b) BUREAU OF MINES REFINING DISTRICTS

* includes al aska and hawali

Fij. 5. Distribution of refineries and cride-oil capacity in the Trited States - January 1974. 
oil is refined to gasoline; distillate fuel oil, jet fuel, and residual fuel oil account for about one-third of the crude oil; and the remainder is processed into more than a dozen other products.

Factors which could significantly change the product stream are: the supply of natural-gas liquids which represented about $6 \%$ of refinery input in 1974; changes in per-capita consumption of gasoline; and natural-gas users switching to fuel oils.

Table 4 gives percentage yields of the refinery products for several recent years. 5

Products and the specific processes used to produce them vary considerably among refineries, causing the kinds and quantities of energy consumed also to vary markedly. Table 5, based on ref. 1 , summarizes general refinery process and production capacities as they are related to refinery size as of 1974. Evaluation of the ref. I information also shows that smaller refineries are used more than larger refineries for lube and asphalt production and used less for other processes. The diverse character of petroleum refining practices is illustrated by Fig. 6 based on ref. 1; rather wide variations exist even after specific processes are grouped under general categories and refineries are aggregated into fairly large districts.

The kinds and qualtities of fuel consumed by U. S. petroleum refineries for recent years are given in Table 6.6

The $3.1 \times 10^{15}$ Btu of energy used by petroleum refineries in $1974^{6}$ represented $4 \%$ of U. S. energy consumption, $15 \%$ of U. S. industrial consumption, and $12 \%$ of the energy content of the crude oil being refined. Industry average energy consumption has decreased slightly in recent years and in 1974 was about $707,000 \mathrm{Btu} / \mathrm{bbl}$ of crude oil. Most 
Table 4. Percenzage ylelds of refined petroleur products from srude ofl in the United Statesa

\begin{tabular}{|c|c|c|c|c|c|c|c|c|}
\hline Finished products & 1965 & 1967 & 1968 & 1969 & 1970 & 1971 & 1972 & $1973^{b}$ \\
\hline Gasoline & 44.4 & 44.0 & 43.9 & 44.8 & 45.3 & 46.2 & 46.2 & 45.6 \\
\hline Jet fuel & 6.2 & 7.5 & 8.3 & 8.2 & 7.5 & 7.4 & 7.2 & 6.8 \\
\hline Ethane (including ethylene) & c & c & c & .2 & .2 & .2 & .2 & .2 \\
\hline Liquified gases & 3.0 & 3.1 & 3.1 & 2.9 & 3.0 & 2.9 & 2.8 & 2.8 \\
\hline Kerosine & 2.9 & 2.7 & 2.7 & 2.6 & 2.3 & 2.1 & 1.8 & 1.7 \\
\hline Distillate fuel ofl & 22.5 & 22.3 & 22.1 & 21.7 & 22.4 & 22.0 & 22.2 & 22.5 \\
\hline Residual fuel oil & 7.5 & 7.7 & 7.2 & 6.8 & 6.4 & 6.6 & 6.8 & 7.7 \\
\hline Petrochemical feedstocks & 2.1 & 2.4 & 2.5 & 2.5 & 2.5 & 2.7 & 2.9 & 2.9 \\
\hline Special naphthas & .9 & .8 & .7 & .7 & .8 & .7 & .7 & .7 \\
\hline Lubricants & 1.B & 1.8 & 1.7 & 1.7 & 1.6 & 1.6 & 1.5 & 1.5 \\
\hline Wax & .2 & .2 & .2 & .2 & .2 & .2 & .1 & .2 \\
\hline Coke & 2.5 & 2.5 & 2.5 & 2.6 & 2.7 & 2.6 & 2.8 & 2.9 \\
\hline Asphalt & 3. $B$ & 3.5 & 3.6 & 3.5 & 3.6 & 3.8 & 3.6 & 3.6 \\
\hline Road ofl & .2 & .2 & .1 & .2 & .3 & .2 & .2 & .2 \\
\hline St111 gas & 3.9 & 3.9 & 4.0 & 4.1 & 4.1 & 3.8 & 3.9 & 3.9 \\
\hline Miscellaneous & .5 &.$\angle$ & .4 & .4 & .3 & .4 & .4 & .4 \\
\hline Shortage & -2.5 & -2.9 & -3.0 & -3.1 & -3.2 & -3.4 & -3.3 & -3.6 \\
\hline Total & 100.0 & 100.0 & 100.0 & 100.0 & 100.0 & 100.0 & 100.0 & 100.0 \\
\hline
\end{tabular}

${ }^{a}$ other unfinished oils added to sude in computing ylelds.

breliminary.

c Included with liquified gases.

Source: U.S. Department of the Interior, Bureau of Mines, Minerals Yearbook-Metals, Minerals, and Fuels, Voi. I, Washington, D.C., 1970, p. 888, and 1973, p. 982. 
Table 5. Distribution of U.S. refinery process and product capacities relative to refinery slze - January 1974

\begin{tabular}{|c|c|c|c|c|c|c|}
\hline \multirow[t]{2}{*}{ Process } & \multicolumn{6}{|c|}{$\begin{array}{c}\text { Percent of U.S. refineries } / \text { percent of U.S. crude-oil capacity }{ }^{a} \\
\text { for refinery size ranges }\left(10^{3} \mathrm{bb} 1 / \text { day }\right) \text { of: }\end{array}$} \\
\hline & $0-25$ & $25-50$ & $0-50$ & $50-100$ & $100-450$ & $0-450$ \\
\hline Vacuum dist1llation & $46.1 / 23.0$ & $76.1 / 28.8$ & $54.7 / 26.6$ & $95.2 / 32.0$ & $100.0 / 39.1$ & $70.0 / 35.2$ \\
\hline Therma1 processes ${ }^{b}$ & $15.7 / 4.6$ & $34.7 / 5.7$ & $21.1 / 5.3$ & $57.1 / 10.6$ & $75.0 / 10.0$ & $36.8 / 9.3$ \\
\hline Catalytic cracking & $20.9 / 12.4$ & $71.7 / 28.2$ & $35.4 / 22.1$ & $97.6 / 31.4$ & $93.2 / 30.1$ & $56.3 / 28.9$ \\
\hline Catalytic reforming & $41.7 / 10.3$ & $84.8 / 18.6$ & $54.0 / 15.3$ & $100.0 / 22.4$ & $100.0 / 22.5$ & $70.0 / 21.2$ \\
\hline Catalytic hydrocracking & $2.6 / 0.6$ & $13.0 / 2.4$ & $5.6 / 1.7$ & $14.3 / 3.4$ & $56.8 / 7.3$ & $16.2 / 5.4$ \\
\hline Catalytic hydrorefining & $4.3 / 1.4$ & $21.7 / 4.4$ & $9.3 / 3.3$ & $35.7 / 12.8$ & $40.9 / 7.3$ & $19.4 / 6.4$ \\
\hline Catalytic hydrotreating & $31.3 / 10.0$ & $87.0 / 24.4$ & $47.2 / 18.9$ & $97.6 / 31.7$ & $100.0 / 32.8$ & $65.2 / 29.9$ \\
\hline A1kylation & $13.0 / 1.8$ & $69.6 / 5.7$ & $29.2 / 4.3$ & $95.2 / 6.1$ & $90.9 / 5.4$ & $36.8 / 5.3$ \\
\hline Aromatics/isomerization ${ }^{c}$ & $2.6 / 0.2$ & $15.2 / 0.7$ & $6.2 / 0.5$ & $45.2 / 3.0$ & $47.7 / 2.3$ & $20.2 / 2.2$ \\
\hline Lube production & $13.0 / 2.8$ & $8.7 / 0.3$ & $11.8 / 1.2$ & $7.1 / 0.4$ & $38.6 / 1.7$ & $16.2 / 1.3$ \\
\hline Asphalt production & $36.5 / 10.6$ & $58.7 / 7.2$ & $42.9 / 8.5$ & $38.1 / 3.6$ & $59.1 / 3.3$ & $44.9 / 4.3$ \\
\hline Coke productior & $4.3 / 0$ & $21.7 / 0$ & $9.3 / 0$ & $30.9 / 0$ & $52.2 / 0$ & $20.6 / 0$ \\
\hline
\end{tabular}

Percent ty size range - not percent of all refineries.

${ }^{b}$ Cracking; visbreaking, coking.

$c_{B T X}$; hydroalkylation; cyclohexane; $C_{4}$ feed; $C_{5}$ feed; $C_{5}$ and $C_{6}$ feed. Production capacity. 
NOTE: DASHED LINES ARE UNITED STATES AVERAGE

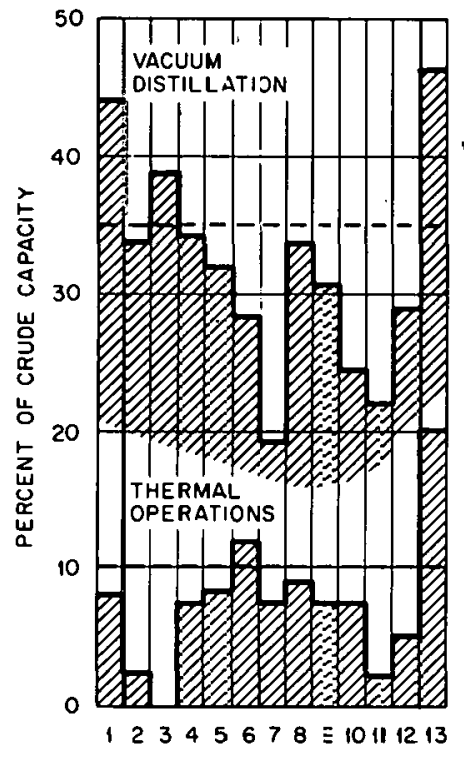

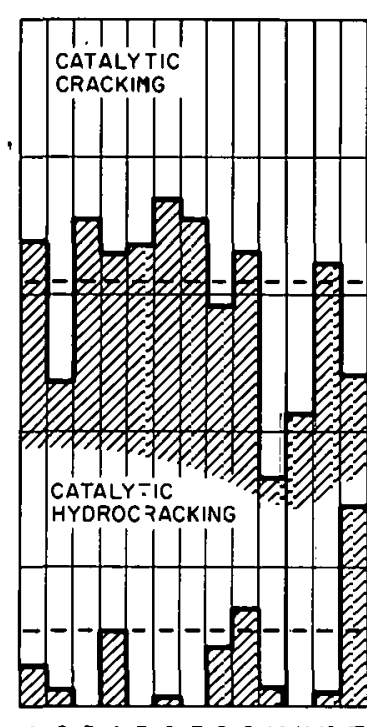

$1234567891011 \hat{20}$
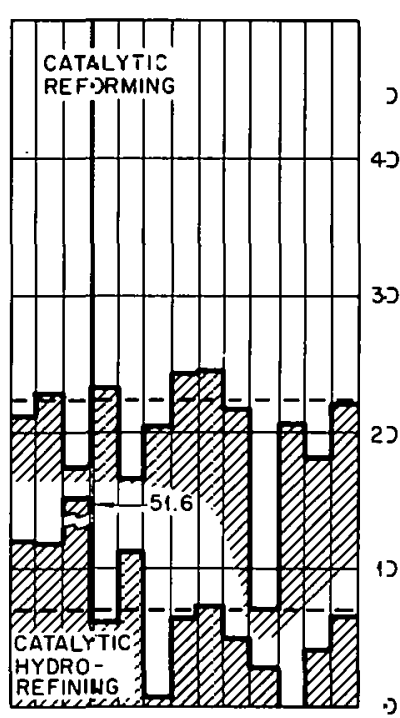

12345578910111213 BUREAU OF MINES DISTRIC
ORNL-OWE 76-5279

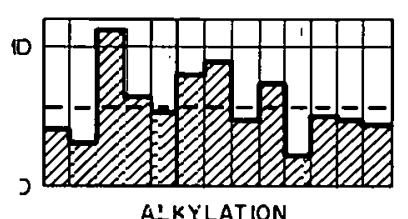
ALKYLATION

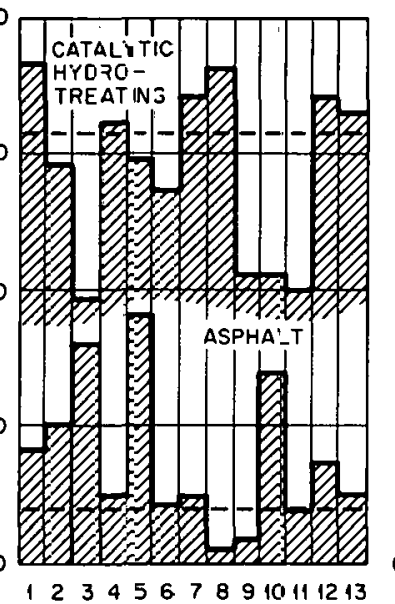

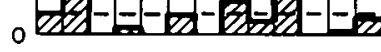

LUBE
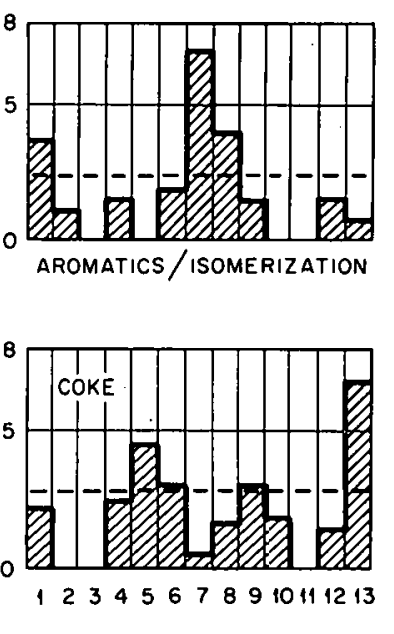

Fig. 6. Frequency of refinery processes by cistric= - January 1974. 
Table 6. Energy consumed at U.S. petroleum refineries

\begin{tabular}{|c|c|c|c|c|c|c|c|c|c|}
\hline Fuel & 1962 & $\frac{\text { Energy }}{1964}$ & $\frac{\left(10^{12}\right.}{1966}$ & $\frac{\text { Btu/year) }}{1968}$ & $\frac{\text { consumed }}{1970}$ & $\frac{\text { for the ye }}{1972}$ & $\frac{\text { ars : }}{1973}$ & 1974 & $\begin{array}{l}\text { Percent of } \\
\text { energy for } \\
\quad 1974\end{array}$ \\
\hline Fuel oil & 262.3 & 266.9 & 251.1 & 263.2 & 267.1 & $276.3^{a}$ & 309.1 & 316.3 & 10.1 \\
\hline Actd sludge & 1.6 & 1.2 & 0.9 & 0.5 & 0.3 & b & $\mathrm{b}$ & $\mathrm{b}$ & b \\
\hline $\begin{array}{l}\text { Gas } \\
\text { LP } \\
\text { Refinery } \\
\text { Matura1 }\end{array}$ & $\begin{array}{r}1701.0 \\
23.7 \\
847.9 \\
829.4\end{array}$ & $\begin{array}{r}1685.0 \\
45.0 \\
785.6 \\
854.4\end{array}$ & $\begin{array}{r}1783.2 \\
9.5 \\
841.4 \\
932.3\end{array}$ & $\begin{array}{r}1942.5 \\
23.7 \\
913.6 \\
1005.1\end{array}$ & $\begin{array}{r}2070.5 \\
16.2 \\
993.6 \\
1060.7\end{array}$ & $\begin{array}{r}2169.8 \\
53.8 \\
1043.0 \\
1073.0\end{array}$ & $\begin{array}{r}2220.2 \\
40.7 \\
1072.5 \\
1107.0\end{array}$ & $\begin{array}{r}2154.9 \\
39.5 \\
1043.1 \\
1072.3\end{array}$ & $\begin{array}{r}68.9 \\
1.3 \\
33.3 \\
34.3\end{array}$ \\
\hline Cole & 309.1 & 321.5 & 322.2 & 325.7 & 313.6 & 338.3 & 400.0 & 374.0 & 11.9 \\
\hline Coal & 19.1 & 21.2 & 25.7 & 19.2 & 12.4 & 8.1 & 7.9 & 5.2 & 0.2 \\
\hline $\begin{array}{l}\text { Purchased } \\
\quad \text { electricity }\end{array}$ & 114.2 & 126.7 & 126.5 & 163.7 & 194.7 & 226.1 & 233.8 & 231.0 & 7.4 \\
\hline $\begin{array}{l}\text { Purchased } \\
\text { steam }\end{array}$ & 25.0 & 27.0 & 25.8 & 29.6 & 33.0 & 45.1 & 45.2 & 47.6 & 1.5 \\
\hline Total & 2432.3 & 2449.5 & 2535.4 & 2744.4 & 2891.6 & 3063.7 & 3216.2 & 3129.0 & \\
\hline$(\mathrm{Btu} / \mathrm{bbI})^{\mathrm{e}}$ & 792 & 756 & 735 & 727 & 729 & 716 & 709 & 707 & \\
\hline
\end{tabular}

${ }^{a_{\text {Includes }}} 2.6 \times 10^{12}$ of crude-o1l consumption.

${ }^{\mathrm{b}}$ Included in fuel oll.

${ }^{C}$ Assumes $10,000 \mathrm{Bta} / \mathrm{kWhr}$.

d Assumes $1333 \mathrm{Btu} / 1 \mathrm{~b}$ steam.

Values are about $5 \%$ higher than referenced data because of adjustment of purcinased energy by efficiency factors. Only barrels of crude input used; total barrels input is about $8 \%$ higher because of unfinished rerun, nazural gas liquids, and other hydrocarbons.

Source: U.S. Department of the Interior, Bureau of Mines, Mineral Industry Surveys, Crua'e Petrolewn, Petroleum Products, and Natural-Gas-Liquids, Washington, D.C., 1962-1973 (f1nal summaries) and April 1974 (monthly statement). 
of the energy is consumed at the refinery by burning natural gas and refinery gas, and slightly more than half of the energy is from refinery products. For example, 57\% of the energy in 1974 was from refinery products - distributed about $60 \%$ from refinery gas, $20 \%$ from oil and LPG, and $20 \%$ from coke. About one-third of the energy comes from natural gas, and a trace $(<0.3 \%)$ comes from coal. A small amount of energy (purchased electricity and steam) comes from oil, gas, coal, nuclear Iuel, and hydropower.

A large regional variation exists in both the amount of energy consumed per unit of crude oil processed and in the kinds of fuel used. Appalachian No. 1 is the only district using a significant amount of coal. Use of natural gas is noticeably less in East-Coast, Appalachian, and North-Midwest districts, where the gas is being replaced primarily by fuel oil. Texas refineries use considerably more natural gas than do other refineries and rank highest in the amount of energy used per barrel, partially because of a higher-than-average amount of refining and probably because of past economic decisions based on inexpensive fuel. Table 7 , based on ref. 6 , shows the average energy consumption of various fuels per untt of crude oil and the large regional variation of energy consumption in 1974. The kinds of fuel used in each district from 1961 to 1973 are given in Appendix A.

Fucls arc used to fire furnaces that heat the materials being processed; to run gas turbines; and to generate steam for injection into the process stream, for operating vacuum jets, for operating steam turbines, for operating steam pumps, and for heating via heat exchangers. About $20 \%$ of the electricity used by refineries is generated at the refinery. Most steam is generated at the refinery, but in six of the 13 Bureau of Mines districts a small amount of steam is purchased. 
Table 7. Energy consumption per unit of crude oil in U. S, petroleum refineries by Bureau of Mines Districts - 1974

\begin{tabular}{|c|c|c|c|c|c|c|c|c|c|c|c|}
\hline \multirow{2}{*}{ District } & \multicolumn{11}{|c|}{ Energy consumption $\left(10^{3} \mathrm{Btu} / \mathrm{bb} 1\right)$ of: } \\
\hline & $\begin{array}{c}\text { Crude } \\
\text { Oil }\end{array}$ & $\begin{array}{l}\text { Distil- } \\
\text { late }\end{array}$ & Residual & $\mathrm{LPG}^{\mathrm{a}}$ & $\begin{array}{l}\text { Natural } \\
\text { Gas }\end{array}$ & $\begin{array}{l}\text { Refinery } \\
\text { Gas }\end{array}$ & Coke & Coal & $\begin{array}{l}\text { Purchased } \\
\text { Electricity }\end{array}$ & $\begin{array}{l}\text { Purchased } \\
\text { Steam }\end{array}$ & Total \\
\hline 1 & & 7.3 & 190 & 2.3 & 62 & 228 & 103 & & 46 & 32 & 671 \\
\hline 2 & & 50 & 206 & 29 & 73 & 195 & 39 & 80 & 80 & 1.5 & 754 \\
\hline 3 & & & 115 & 13 & 64 & 163 & 97 & 20 & 58 & & 530 \\
\hline 4 & & 4.4 & 131 & 9.3 & 55 & 235 & 103 & & 52 & & 590 \\
\hline 5 & & & 110 & 0.9 & 26 & 183 & 104 & & 49 & & 473 \\
\hline 6 & 0.3 & 1.6 & 27 & 5.9 & .274 & 242 & 75 & & 45 & & 671 \\
\hline 7 & & 5.0 & 10 & 4.4 & 379 & 220 & 121 & & 60 & 0.2 & 800 \\
\hline 8 & & 5.4 & 1 & 2.2 & 524 & 223 & 83 & & 39 & & 878 \\
\hline 9 & & 23 & 14 & 12 & 211 & 259 & 49 & & 50 & 31 & 649 \\
\hline 10 & 0.7 & 31 & 38 & 16 & 261 & 151 & 35 & & 28 & & 561 \\
\hline 11 & & & 15 & 35 & 246 & 159 & 56 & & 29 & & 540 \\
\hline 12 & & 3.5 & 89 & 8.2 & 171 & 224 & 109 & & 48 & & 653 \\
\hline 13 & & 11 & 41 & 21 & 189 & 265 & 81 & & 83 & 21 & 712 \\
\hline
\end{tabular}

aiquified petroleum gas. 
Substitution among fuels is feasible and likely to occur as the relative prices and availability of fuels shift. For example, the introduction of new equipment could shift fuel-oil and natural-gas consumption to coal consumption. Modifying existing equipment so that coal can be used generally is impractical.

\section{REFINING PROCESSES}

Genera 1

Energy requirements for petroleum refineries vary rather widely because of the crude-oil composition, the processes and equipment used, and the products. Heavy crude oils require somewhat more energy to be refined than do light crude oils to yield similar products; likewise, high-sulfur crude oils require more energy than do low-sulfur crude oils. Energy requirements also increase as there is an increase in products such as lubricants, high-octane gasoline, and petrochemical feedstocks, and proçesses and equipment also affect energy requirements.

Modern refineries are reducing energy requirements by: using heat exchange; using more insulation; more effectively controlling combustion; recovering heat from exhaust gases; eliminating straight condensing-steam turbines; using back-pressured steam turbines; and using turboexpanders to "let down" process streams. Some refiners have established task groups to reduce energy consumption; reduction goals are un lhe order of $5 \%$ per year.

The purpose of this section is to indicate approximate refinery energy requirements and possible opportunities to conserve energy. Further information about the various processes is given in Appendix $B$. 
For some processes only a representative energy-requirement value is given; for others a range of values is given. In all cases a representative value was used to estimate the potential for saving energy. Steam requirements were converted at the rate of $1333 \mathrm{Btu} / 1 \mathrm{~b}$, and electricity was converted at $10,000 \mathrm{Btu} / \mathrm{kWhr}$. When fuel energy was given as heat absorbed, an efficiency of $75 \%$ (based on low-heating value) was used to determine fuel consumption. The energy savings estimated for this report are based on the following:

1. The process rate according to the 1974 values of ref. 6 .

2. A $10 \%$ fuel savings by better furnace designs and control and by more use of heat recovery, based on literature articles ${ }^{7,8}$ and assuming that two-thirds of the units have efficiencies that can be improved from about 75 to $88 \%$.

3. Recovery of energy by additional heat exchange between process streams before heat is rejected to the environment. The average temperature of energy entering the coolers is assumed to be $149^{\circ} \mathrm{C}$ $\left(300^{\circ} \mathrm{F}\right)$. A reduction of this temperature to $121^{\circ} \mathrm{C}\left(250^{\circ} \mathrm{F}\right)$ is used to estimate the savings. 9

4. Use of hydraulic turbines and more efficient prime movers to increase the energy efficiency from 30 to $70 \%$ on one-third of the applicable capacity requirements, giving a $20 \%$ savings of these electrical energy requirements.

Radiation-convection heat losses from refinery equipment and piping is common to all processes. In general, insulation has been provided based on an economic trade-off of the cost of the insulation vs the value of the heat. Even though the value of energy has been relatively low, 
a large fraction of the potential (uninsulated) heat loss has been eliminated. Still remaining is a potential for a small, economically justifiable energy savings based on a higher value of energy. Insulation requirements for new refineries. can be expected to be based on higher energy values than in the past; additional insulation of existing refineries can be expected only where it is practical and economically justified. Quantitative estimates indicating the magnitude of radiationconvection losses and potential savings, based on a large modern refinery, are given for a few of the processes. The estimates indicated that, if refineries have provided enough insulation to limit surface temperatures to about $67^{\circ} \mathrm{C}\left(150^{\circ} \mathrm{F}\right)$, additional insulation to reduce surface temperatures to about $32^{\circ} \mathrm{C}\left(90^{\circ} \mathrm{F}\right)$ represents a rather small potential for energy savings relative to other items. Thus savings from insulation improvement are ignored for the other processes.

Electricity requirements for instrumentation and lighting of process areas are small compared to other electrical requirements for the process. Likewise, because most of the equipmenl is uilenclosed, there is no significant space heating or cooling requirement for the processes. These miscellaneous requirements for electricity are considered to be small enough that their inclusion or exclusion in the consumption values for a process would not have an important effect. Moreover, they are amenable to generally known conservation measures sucli as reduction of light intensity within safe and legal limits and adjustment of temperature and humidity controls to levels requiring less energy. 
Refiners often refer to the combined processes of desalting, atmospheric distillation, vacuum distillation, and gas separation as "crude distillation," but in this study these processes are considered separately.

\section{Desalting}

Energy requirements for desalting are quite low, consisting of: energy to pump the oil through the desalting system and to inject water into the system; heat to raise the oil and water temperature to about $121^{\circ} \mathrm{C}\left(250^{\circ} \mathrm{F}\right)$; and electricity to maintain the high-potential electric field. Heating the oil to $121^{\circ} \mathrm{C}$ will require about $30,000 \mathrm{Btu} / \mathrm{bbl}$, but here this amount is included in the distillation requirements (heat losses from the desalting system are considered a desalting-process requirement). Crude-oil pumping energy is about $0.04 \mathrm{kWhr} / \mathrm{bbl}$; pumping energy required to add water depends on the salt content of the crude oil. Low-salt crude oil requires about 1 vol \% of water whereas high-salt crude oil may require water equal to $50 \%$ of the crude oil volume. As an example, the pumping energy required for desalting on a 5 vol \% basis is about $0.01 \mathrm{kWhr} / \mathrm{bb} 1$.

The energy requirement for the high-potential electrical field is about $0.01 \mathrm{kWhi} / \mathrm{bl} 1$.

Assuming that most refineries have some insulation installed, the heat loss is estimated to be about $50 \mathrm{Btu} / \mathrm{bbl}$. If half of this total were saved and if $80 \%$ of the crude-oil input were desalted, savings based on the 1974 processing rate would be about $10^{11}$ Btu/year.

If not being practiced, the recovery of energy from discharged brine by heat exchange to inlet feed (water or oil) would conserve 
energy. For example, if half of the energy in the discharged brine were utilized when 5 vol \% of water is used for desalting, about $2500 \mathrm{Btu} / \mathrm{bbl}$ would be conserved, amounting to $10^{13} \mathrm{Btu} /$ year.

Other energy-conserving techniques associated with desalting, such as reducing pump energy by means of lower pressure drops and more efficient pumps, probably would be of very low priority and perhaps be uneconomical. Alternative measures might include longer storage periods and/or use of only chemicals to promote separation of salts from the oil. However, the small amount of energy required for the high-potential field appears to be easily justified.

Atmospheric Distillation

Energy requirements for atmospheric distillation consist of fuel to heat the crude oil, steam to be injected into the atmospheric tower and stripper, and energy to pump the fluids. Energy required to heat the crude oil depends on the extent of heat exchangè, pèrceñt vảporizized, and composition of the feed. Typically the required temperature increase supplied by furnace heat will be 66 to $135^{\circ} \mathrm{C}$ (150 to $275^{\circ} \mathrm{F}$ ) and will require 25,000 to $85,000 \mathrm{Btu} / \mathrm{bbl}$ of crude oil. ${ }^{3}$ Allowing for pipe-still efticiency results in an estimated fuel input (usually gas) of 35,000 to $145,000 \mathrm{Btu} / \mathrm{bbl}$. Reboiling of reflux requires additional heat as shown by Table 8 . Data from a large modern refinery indicate that about 80,000 Btu of fuel energy is required per barrel to vaporize $45 \%$ of a medium-gravity feed. Most of the electrical energy is used to pump the crude oil, the products, and the reflux, and to power the air-cooled heat-exchanger and air-preheat fans. The electricity required is about $0.06 \mathrm{kWhr} / \mathrm{bbl}$. 
Table 8. Heat input for refluxing

\begin{tabular}{|c|c|c|c|c|}
\hline \multirow{2}{*}{$\begin{array}{l}\text { Reflux ratio } \\
\text { based on top } \\
\text { product }\end{array}$} & \multicolumn{4}{|c|}{$\begin{array}{l}\text { Heat input (Btu/bbl) for } \\
\text { percentage vaporized of: }\end{array}$} \\
\hline & 20 & 40 & 60 & 80 \\
\hline 1 & 5,000 & 10,000 & 16,000 & 21,000 \\
\hline 3 & 15,000 & 31,000 & 47,000 & 62,000 \\
\hline 5 & 26,000 & 52,000 & 78,000 & 103,000 \\
\hline 10 & 52,000 & 103,000 & 154,000 & 206,000 \\
\hline
\end{tabular}

Source: W. L. Nelson, Guide to Refinirig Costs, 2 nd ed., The Petroleum Publishing Company, Tulsa, Okla. (1970), p. 35.

Steam requirements vary markedly depending on the crude-oil gravity and the fraction vaporized. Steam at 100 to 150 psig with some superheat at a typical rate of 1 to 2 and 4 to $8 \mathrm{lb} / \mathrm{bbl}$ may be used in the atmospheric column and stripper respectively.

Energy requirements for atmospheric distillation of crude oil in a plant making liberal use of heat exchange and air preheat are approximately as follows:

\begin{tabular}{|c|c|c|c|}
\hline & $\begin{array}{c}\text { Energy requirement } \\
(\mathrm{Btu} / \mathrm{bb} \mathrm{I})\end{array}$ & $\frac{\text { Process }}{\left({ }^{\circ} \mathrm{C}\right)}$ & $\frac{\text { temperature }}{\left({ }^{0} \mathrm{~F}\right)}$ \\
\hline Electricity ${ }^{a}$ & 6,000 & & \\
\hline Fuel & 80,000 & 375 & 675 \\
\hline Steam & 10,000 & 260 & 500 \\
\hline TOTAL & 96,000 & & \\
\hline
\end{tabular}

Energy is lost from the atmospheric distillation system as: heat in the flue gases from the tube still; convection-radiation losses from the system; heat rejected by air- and water-cooled heat exchangers; and heat in blowdown water. 
Heat lost with the flue gas depends on furnace design, excess air, temperature of the charge, air preheat, and to a lesser extent the type of fuel (oil or gas). Gas is the preferred fuel because the flames radiate less intensely and because the burners are less expensive. ${ }^{10}$ If not being practiced, the recovery of heat from the flue gas, such as by preheating the combustion air or generating steam, can markedly improve energy efficiency.

Convection-radiation losses from the system are primarily from the pipe still (equivalent to 3 to $4 \%$ of the fuel heat); other potential losses are from the atmospheric tower and associated high-temperature piping (up to $700^{\circ} \mathrm{F}$ ). Insulation usually is provided and will limit the equipment and piping losses, excluding losses from the furnaces, to about $700 \mathrm{Btu} / \mathrm{bbl}$ of feed. Thus a potential energy savings could result by using more insulation.

Air- and water-cooled heat exchangers are used to cool the recycle and product streams, such as saturate gas, naphtha, kerosine, and fuel oil. Atmospheric-tower residual can be transferred to a vacuum distillation system without cooling. Typically the atmospheric dist1llation portion of a modern integrated refinery rejects $35,000 \mathrm{Btu} / \mathrm{bb} \perp$ via the air-cooled heat exchangers used to cool product streams varying from 93 to $149^{\circ} \mathrm{C}\left(200\right.$ to $\left.300^{\circ} \mathrm{F}\right)$. Thus these streams are potential supplies of low-temperature heat.

Blowdown water mainly comes from steam infected into the process stream, and because it is discharged at a low temperature [ $38^{\circ} \mathrm{C}\left(100^{\circ} \mathrm{F}\right)$ ] it does not represent a significant heat loss. 
Apparently no competitive process exists to replace atmospheric distillation for primary separation. Opportunities to conserve energy in this process include improved insulation; optimization of equipment design and operation parameters (i.e., more fractionating trays, increased flooding of trays, and less refluxing); full use of heat exchange; and careful analysis and control of the process to preclude "overrefining."

Potential savings of energy in the atmospheric-distillation process are estimated for the 1974 process rate as follows:

\begin{tabular}{|c|c|}
\hline & Savings \\
\hline Conservation measure & $\left(10^{13} \mathrm{Btu} /\right.$ year $)$ \\
\hline $\begin{array}{l}\text { Better furnace design and control and more use of } \\
\text { heat recovery ( } 10 \% \text { of consumption) }\end{array}$ & 4.0 \\
\hline Improved fractionation ( $5000 \mathrm{Btu} / \mathrm{bb} 1$ less energy) & 2.2 \\
\hline $\begin{array}{l}\text { Recovery and use of one-fourth of the low-grade heat } \\
\text { rejected by air- and water-cooled heat exchangers }\end{array}$ & 3.9 \\
\hline Better insulation ( $3 \mathrm{bu} \mathrm{Btu} / \mathrm{bbl}$ ) & 0.2 \\
\hline TOTAL & 10.3 \\
\hline
\end{tabular}

This total is about $3.2 \%$ of the energy used for refining petroleum. Vacuum D1sc1llar1on

Energy requirements for vacuum distillation consist of fuel to heat the feed, reboil heat, motive steam for steam jet-ejectors and possibly for injection into the vacuum tower, and energy to pump the fluids. Feed to the vacuum still must be 399 to $427^{\circ} \mathrm{C}\left(750\right.$ to $\left.800^{\circ} \mathrm{F}\right)$, a temperature range 66 to $93^{\circ} \mathrm{C}\left(150\right.$ to $\left.200^{\circ} \mathrm{F}\right)$ hotter than the temperature of the residual discharged from the atmospheric column. The heat required also depends on the composition of the residual, the degree of 
vaporization desired, and the vacuum employed. Heating the feed will require 40,000 to $60,000 \mathrm{Btu} / \mathrm{bbl}$ of feed and, allowing for efficiency, the fuel (usually gas) input will equal 60,000 to $90,000 \mathrm{Btu} / \mathrm{bb} 1$ of feed. Steam for operating steam jets at 100 to $150 \mathrm{psig}$ depends on the quantity of noncondensibles that must be removed, a figure which in turn depends on whether or not steam stripping is used and on the amount of leakage into the system. When steam is injected inco the tower, the minimum pressure is limited by the temperature of the condensing warer. Other factors affecting steam-jet consumption are the design, the matching of operating conditions with the design, the desired vacuum, and the temperature of the condensing system. Although consumption can vary considerably, typical steam-jet usage is $51 \mathrm{~b}$ of 100 - to 150-psig steam per barrel of feed. This value is based on a two-stage ejector providing a $75-\mathrm{mm}-\mathrm{Hg}$ pressure when handling about $1.5 \mathrm{lb} / \mathrm{bbl}$ of noncondensibles. Process steam is sometimes used to enhance the fractionation; the amount required varies widely depending on the pressure (vacuum), percent vaporized, and feed composition. Typically 7 to 12 pounds of 100- to 150-psig steam is required per barrel of feed.

Most of the electrical energy is used to pump the feed, the products, and the recycle and to power the air-cooled heat-exchanger and airpreheat fans. The electricity requirement is about $0.3 \mathrm{kWhr} / \mathrm{bbl}$ of feed. Approximate energy requirements for vacuum distillation of the residual from atmospheric columns are as follows: 


\begin{tabular}{|c|c|c|c|}
\hline & $\begin{array}{l}\text { Energy requirement } \\
\quad(\text { Btu/bb1 feed) }\end{array}$ & $\frac{\text { Process }}{\left({ }^{\circ} \mathrm{C}\right)}$ & $\frac{\text { temperature }}{\left({ }^{O} \mathrm{~F}\right)}$ \\
\hline Electricity ${ }^{a}$ & 3,000 & & \\
\hline Fuel & 75,000 & 413 & 775 \\
\hline \multicolumn{4}{|l|}{ Steam } \\
\hline Jets & 9,000 & 260 & 500 \\
\hline Process & 13,000 & 260 & 500 \\
\hline TOTAL $^{a}$ & 100,000 & & \\
\hline
\end{tabular}

Energy is lost from the vacuum distillation system as: heat in the flue gases from the tube still; convection-radiation losses from the system; heat rejected by air- and water-cooled heat exchangers; and heat in blowdown water.

Heat lost in the flue gas depends on furnace design, excess air, temperature of the charge, air preheat, and to a lesser extent the type of fuel (oil or gas). Gas is the preferred fuel because the flames radiate less intensely and because the burners are less expensive. ${ }^{10}$ If not being practiced, recovery of heat from the flue gas, such as by air preheat or generation of steam, can markedly improve energy efficiency.

Convection-radiation losses from the system are primarily from the pipe still (equivalent to 3 to $4 \%$ of the fuel heat); other potential losses are from the vacuum tower and associated high-temperature piping. Insulation usually is provided and will limit the equipment and piping losses, excluding losses from the furnace, to about $700 \mathrm{Btu} / \mathrm{bbl}$ of feed. Thus a potential energy savings could result by using more insulation. 
Air- and water-cooled heat exchangers are used to cool recycle and product streams. Residual can be transferred for further processing, such as to the coker, without cooling. Typically the vacuum distillation portion of a modern integrated refinery would reject about $25,000 \mathrm{Btu} / \mathrm{bbl}$ of feed via air-cooled heat exchangers used to cool product and recycle streams varying from 121 to $177^{\circ} \mathrm{C}\left(250\right.$ to $\left.350^{\circ} \mathrm{F}\right)$. Thus these streams are potential supplies of low-temperature heat. An additional $9,000 \mathrm{Btu} / \mathrm{bb} 1$ of feed is rejected to produce the vacuum. Assuming proper design and operation of the steam jet system, conserving energy can be achieved only by using different kinds of equipment to produce the vacuum.

Water is blown down from the steam-ejectors, and steam is sometimes injected into the process stream. But heat lost beyond the amount accounted for in the condensers is not significant.

Apparently no competitive process exists to replace vacuum distillation. Opportunities to conserve energy in this process include improved insulation, optimization of equipment destgn and operation parameters, and full use of heat exchange.

Use of mechanical pumps to evacuate the system would reduce energy requirements substantially. Capital and maintenance costs would be higher, but a considerable compensating savings in energy costs would result. Mechanical vacuum pumps would use 70 to $90 \%$ less energy than would steam jets, ${ }^{11}$ but adequate reliability would have to be demonstrated before refiners would be willing to consider a substitution.

Potential savings of energy in the vacuum-distillation process are estimated for the 1974 process rate as follows: 


\begin{tabular}{lc}
\hline \multicolumn{1}{c}{ Conservation measures } & Savings \\
\cline { 2 - 2 } $\begin{array}{l}\text { Better furnace design and control and more use } \\
\text { of heat recovery (10\% of consumption) }\end{array}$ & 1.4 \\
$\begin{array}{l}\text { Improved fractionation (5000 Btu/bb1 less } \\
\text { energy) }\end{array}$ & 0.8 \\
$\begin{array}{l}\text { Recovery and use of one-fourth of the low-grade } \\
\text { heat rejected by air- and water-cooled heat } \\
\text { exchangers }\end{array}$ & 1.5 \\
$\begin{array}{l}\text { Mechanical vacuum pumps (80\% savings) } \\
\begin{array}{l}\text { Better insulation (350 Btu/bbl feed) } \\
\text { TOTAL }\end{array}\end{array}$ & 1.1 \\
\hline
\end{tabular}

This total is about $1.3 \%$ of the energy used for refining petroleum. Gas Separation

Energy requirements for the gas separation system consist of heating the feed and recycle streams and pumping the fluids through the system. Using the system shown in Fig. B.4 of Appendix B, feed to the debutanizer (cooled overhead from the atmospheric tower) is heated to about $149^{\circ} \mathrm{C}$ $\left(300^{\circ} \mathrm{F}\right)$ by heat exchange. Additional heat is added to the debutanizer tower by a circulating side stream. Overhead from the debutanizer is cooled, vented, and then fed to the depropanizer, the bottom fraction Irom the debutanizer is transferred to a gasoline splitter. In the depropanizer the propane is separated from the butane. The depropanizer feed is heated by heat exchange and additional heat is added to a circulating side stream. In the gasoline splitter the gasoline is separated into light and heavy components.

Steam may be used as the source of heat. As an example, the system shown in Fig. B. 4 would require about 6.4 and 40 pounds of $260^{\circ} \mathrm{C}\left(500^{\circ} \mathrm{F}\right)$. 
150-psig steam per barrel of feed for the depropanizer and gasoline splitter respectively.

Most of the electrical energy is used to pump the feed, the products, and the recycle and to power the air-cooled heat-exchanger fans.

Approximate energy requirements for gas separation are as follows:

\begin{tabular}{|c|c|c|c|}
\hline & $\begin{array}{c}\text { Energy requirement } \\
\text { (Btu/bb1 feed) }\end{array}$ & $\frac{\text { Process }}{\left({ }^{\circ} \mathrm{C}\right)}$ & $\frac{\text { temperature }}{\left({ }^{\mathrm{O}} \mathrm{F}\right)}$ \\
\hline Electricity ${ }^{a}$ & 1,800 & & \\
\hline File 1 nr steam & 62,000 & 260 & 500 \\
\hline TOTAL & 64,000 & & \\
\hline
\end{tabular}

In a plant using heat exchange to heat the feed, energy is mainly required by the reboilers to heat recirculating side streams of the fractionation towers. For example, providing this heat to the depropanizer and gasoline splitter requires about 43,000 Btu/bbl of feed to heat the streams to 121 to $149^{\circ} \mathrm{C}\left(250^{\circ}\right.$ to $\left.300^{\circ} \mathrm{F}\right)$. Thus these are opportunities to provide energy by heat exchange from streams above $204^{\circ} \mathrm{C}\left(400^{\circ} \mathrm{F}\right)$.

Energy is lost from the saturate-gas-separation system as: convection-radiation losses from the system and as heat rejected by airand water-cooled heat exchangers.

Insulation usually is provided and will limit the convectionradiation losses from the equipment and piping to about $2000 \mathrm{Btu} / \mathrm{bbl}$ of feed. Thus a potential energy savings could result by using more insulation. 
Air- and water-cooled heat exchangers are used to cool the recycle and product streams. Here this total equals about $80,000 \mathrm{Btu} / \mathrm{bbl}$ of feed. The fluids being cooled range in temperature from 77 to $110^{\circ} \mathrm{C}$ $\left(170\right.$ to $\left.230^{\circ} \mathrm{F}\right)$ and thus are potential supplies of low-temperature heat. No apparent competitive process exists to replace the fractionation system. Opportunities for energy conservation in this process are improved insulation, optimization of equipment design and operation parameters (e.g., less refluxing), and full use of heat exchange. Providing more plates allows less refluxing for a given separation, and fractionation systems are designed with a trade-off between the number of plates and the reflux ratio. Refluxing is energy-intensive because it requires energy for the reboilers and energy removal in the condensers. Thus energy conservation is possible through capital expenditures for more trays.

Potential savings of energy in the gas-separation process are estimated for the 1974 process rate as follows:

\begin{tabular}{lc}
\hline \multicolumn{1}{c}{ Conservation measure } & $\begin{array}{c}\text { Savings } \\
\left(1.0^{13} \text { Bt.11/year) }\right.\end{array}$ \\
\hline $\begin{array}{l}\text { Better furnace design and control and more use of } \\
\text { heat recovery (10\% of consumpt1on) }\end{array}$ & 0.27 \\
$\begin{array}{l}\text { Recovery and use of one-fourth of the low-grade heat } \\
\text { rejected by air- and water-cooled heat exchangers }\end{array}$ & 0.91 \\
$\begin{array}{l}\text { Improved fraction (5000 Btu/hbl less energy) } \\
\text { Better insulation (1000 Btu/bbl feed) }\end{array}$ & 0.22 \\
TOTAL
\end{tabular}

This total is about $0.5 \%$ of the energy used for refining petroleum. 


\section{Cracking}

Thermal cracking and visbreaking

Energy requirements for a thermal-cracking system consist of fuel to heat the feed, energy to pump the fluids (sometimes steam-driven pumps), and sometimes steam to be used for stripping. Feed to the unit coming directly from the crude-oil distillation system would be at a temperature of about $3 \% 1^{\circ} \mathrm{C}\left(700^{n} \mathrm{r}\right)$. Heat exchange in the fractionator recovers some of the heat from product streams. E'nergy reported to be required for the thermal-cracking process varies widely, partly because of the temperature of the feed to the process (i.e., feed which must be heated from ambient to process temperatures will require abour 200,000 Btu/bb1 more heat from fuel than feed which is transferred directly from the distillation unit at a high temperature) and the amount of recycling and refluxing practiced.

Energy consumption by a visbreaking unit is similar to that for a thermal-cracking unit, but somewhat less because of less recycling, and some steam is used to produce the vacuum (if vacuum fractionation is practiced).

Reported energy requirements for thermal cracking are as follows: ${ }^{3}$

\begin{tabular}{|c|c|c|c|}
\hline & $\begin{array}{l}\text { Energy requirement } \\
\text { (Btu/bbl feed) }\end{array}$ & $\frac{\text { Process }}{\left.{ }^{o} \mathrm{C}\right)}$ & $\frac{\text { temperature }}{\left({ }^{\circ} F\right)}$ \\
\hline Electricity ${ }^{a}$ & 6,000 to & & \\
\hline Fue1 & 400,000 to $1,000,000$ & 521 & 970 \\
\hline Steam ${ }^{b}$ & 67,000 to & 260 & 500 \\
\hline TOTAL & 470,000 to $1,300,000$ & & \\
\hline
\end{tabular}

${ }^{a}$ Electricity converted to energy requirement based on $10,000 \mathrm{Btu} / \mathrm{kWhr}$.

${ }^{b}$ Assumes feed, bottom, and recycle pumps are steam-driven. 
Energy requirements for visbreaking from two sources are as follows:

\begin{tabular}{|c|c|c|c|c|}
\hline & \multicolumn{2}{|c|}{$\begin{array}{c}\text { Energy requirement } \\
(\mathrm{Btu} / \mathrm{bbl} \text { feed })\end{array}$} & \multirow{2}{*}{$\frac{\text { Process }}{\left({ }^{\circ} \mathrm{C}\right)}$} & \multirow{2}{*}{$\frac{\text { temperature }}{\left({ }^{\mathrm{O}} \mathrm{F}\right)}$} \\
\hline & $\operatorname{Ref} \cdot 3^{a}$ & Ref. $12^{b}$ & & \\
\hline Electricity & 400 to 4,300 & 18,000 & & \\
\hline Fuel & 125,000 to 210,000 & 260,000 & 482 & 900 \\
\hline Steam & 19,000 to 39,000 & $-107,000^{\mathrm{d}}$ & 260 & 500 \\
\hline TOTAL & 144,000 to 253,000 & 171,000 & & \\
\hline
\end{tabular}

W. L. Nelson, Guide to Refining Costs, 2nd ed., The Petroleum Publishing Company, Tulsa, Okla. (1970), p. 87.

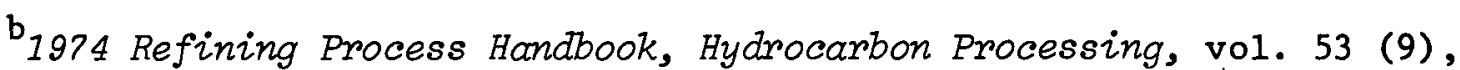
Gulf Publishing Company, Houston, Tex., September 1974, p. 123.

Electricity converted to energy requirement based on 10,000 $\mathrm{Btu} / \mathrm{kWhr}$.

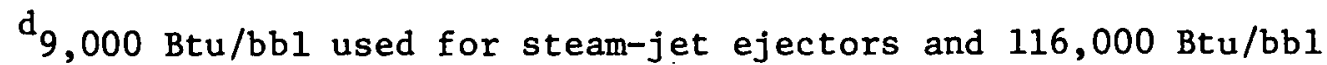
produced by the process.

Date from an industria1 snurce are as follows:

\begin{tabular}{lc}
\hline & $\begin{array}{c}\text { Energy requirement } \\
\text { (Btu/bbl feed) }\end{array}$ \\
\hline $\begin{array}{l}\text { Electricity } \\
\text { Fuel }\end{array}$ & 5,000 \\
Steam & 110,000 \\
Pumps & \\
Process & 9,000 \\
Total & 8,000 \\
\hline \multicolumn{1}{c}{ a Electricity converted of energy } \\
requirement based on 10,000 Btu/kWhr. \\
b Another 25,000 Btu/bbl was \\
obtained by heat exchange with another \\
refining process.
\end{tabular}

Although potential savings of energy from conservation techniques or use of alternate thermal-cracking or visbreaking processes are uncertain, 
an estimate based on mid-range requirements and the 1974 process rate is as follows:

\begin{tabular}{lc}
\hline \multicolumn{1}{c}{ Conservation measure } & $\begin{array}{c}\text { Savings } \\
\left(10^{13} \text { Btu/year) }\right.\end{array}$ \\
\hline $\begin{array}{l}\text { Better furnace design and control and more use } \\
\text { of heat recovery (10\% of consumption) } \\
\text { Thermal cracking } \\
\text { Visbreaking }\end{array}$ & 0.53 \\
$\begin{array}{l}\text { Improved fractionation (5000 Btu/bbl) } \\
\text { Mechanical vacuum pumps (80\% savings) }\end{array}$ & 0.06 \\
$\begin{array}{l}\text { Recovery and use of one-fourth of the low-grade heat } \\
\text { rejected by air- and water-cooled heat exchangers } \\
\text { ToTAL }\end{array}$ & 0.05 \\
\hline
\end{tabular}

This total is about $0.3 \%$ of the energy used for refining petroleum. Coking

Energy requirements for delayed coking consist of steam for driving the water-jet pumps (used to remove coke from the soaking drums and sometimes to drive feed pumps), fuel for the heater, and electricity for other pumps. Sometimes steam is also used for reboiling in the fractionator section.

Energy requirements for fluid coking consist of steam for fluidizing the reactor bed (and for gasification in the alternate version) and sometimes for driving feed pumps. Electricity is also used for pump drives. No external fuel supply is required for process heating and a net production of steam can result.

The substantially lower energy consumption shown for the fluid process is misleading because energy is supplied by burning coke 
produced in the process. Overall differences in energy consumption probably are not significant, and the choice has been influenced by the kind of coke desired and other considerations such as maintenance and operating continuity.

Approximate energy requirements for coking are as follows:

\begin{tabular}{|c|c|c|c|c|c|c|c|}
\hline & \multicolumn{3}{|c|}{$\begin{array}{c}\text { Energy requirement } \\
\text { (Btu/bb1 feed) }\end{array}$} & \multicolumn{4}{|c|}{$\frac{\text { Process temperature }}{\text { Delayed Fluid }}$} \\
\hline & Delayed & Fluid ${ }^{a}$ & Fluid $^{b}$ & ${ }^{\circ} \mathrm{C}$ & ${ }^{\circ} F$ & ${ }^{\circ} \mathrm{C}$ & ${ }^{\circ} \mathrm{F}$ \\
\hline Electricity ${ }^{c}$ & 70,000 & 15,000 & 160,000 & & & & \\
\hline Fue1 & 80,000 & 0 & 0 & 499 & 930 & 538 & 1000 \\
\hline Steam & 45,000 & 100,000 & $-134,000$ & 399 & 750 & 260 & 500 \\
\hline TOTAL & 195,000 & 115,000 & 26,000 & & & & \\
\hline
\end{tabular}

Without gasification.

$\mathrm{b}_{\text {With }}$ gasification.

$c_{\text {Electricity converted to energy requirement based on } 10,000}$ $\mathrm{Btu} / \mathrm{kWhr}$.

The extent to which a representative refinery might utilize the waste energy from coking units is unknown and dominates any attempt to estimate potential energy conservation. A limiting-type value based on the extent of coking in 1974, on the energy requirements, and on the assumption of a $10 \%$ savings, is $0.5 \times 10^{13} \mathrm{Btu} /$ year -1 ess than $0.2 \%$ of petroleum refinery consumption.

\section{Catalytic cracking}

Energy requirements for catalytic-cracker units consist of energy to pump the feed, recycle, and products - including air to supply the regenerator and to move the catalyst. In the airlift (moving-bed unit) and sometimes fluid-bed units, fuel is used to heat the feed before it 
moves to the reactor vessel and steam is generated in cooling the catalyst. In the fluid-bed process the hot, regenerated catalyst supplies some and often all of the energy to heat the feed. The catalyst is regenerated at a temperature of 566 to $760^{\circ} \mathrm{C}\left(1050\right.$ to $\left.1400^{\circ} \mathrm{F}\right)$ at pressures of 10 to 30 psig. Steam is used to strip the hydrocarbon products from the catalyst and sometimes is used in the fractionator system.

Flue gas from the regenerator is pressurized, hot, and combustible conditions which provide opportunities for recovering energy and which if fully exploited could make FCCU net energy-generators. Approximate energy requirements for catalytic cracking are as follows:

\begin{tabular}{|c|c|c|c|}
\hline & $\begin{array}{l}\text { Energy requirement } \\
\quad(\text { Btu/bbl feed })\end{array}$ & $\frac{\text { Process }}{\left({ }^{\circ} \mathrm{C}\right)}$ & $\frac{\text { temperature }}{\left({ }^{\circ} \mathrm{F}\right)}$ \\
\hline \multicolumn{4}{|c|}{ Airlift cracker ${ }^{a}$} \\
\hline Electricity ${ }^{\mathrm{b}}$ & 22,000 & & \\
\hline Fuel & 140,000 & 482 & 900 \\
\hline Steam & $-67,000$ & 260 & 500 \\
\hline Total & 95,000 & & \\
\hline \multicolumn{4}{|l|}{ FCUU } \\
\hline Electricity ${ }^{\mathrm{b}}$ & 50,000 & & \\
\hline Steam & 35,000 & 260 & 500 \\
\hline Total & 85,000 & & \\
\hline \multicolumn{4}{|l|}{ FCUR' } \\
\hline Electricity & 57,000 & & \\
\hline Fuel & 50,700 & 482 & 900 \\
\hline Steam & $-177,000$ & 260 & 500 \\
\hline Tota1 & $-69,000$ & & \\
\hline \multicolumn{4}{|c|}{$\begin{array}{l}\text { a Source: } 1970 \text { Refining Process Handbook, Hydrocarbon } \\
\text { Processing, Vo1. } 49 \text { (9), Gulf Publishing Cumpally, Houston, } \\
\text { Tex., September } 1970, \text { p. } 174 \text {. } \\
\text { b Electricity converted to energy requirement based on } \\
\text { 10,000 Btu/kWhr. }\end{array}$} \\
\hline
\end{tabular}


Airlift-type catalytic crackers appear to use more energy than fluid-bed-type crackers - the previous tabulation indicates about $12 \%$ more. Nelson data, ${ }^{3}$ although indicating considerably higher energy requirements for both types of crackers, also shows the air-lift type requiring about $12 \%$ more energy. Assuming $10,000 \mathrm{Btu} / \mathrm{bb} 1$ savings and the 1974 process rate, replacing air-lift crackers with FCCU would conserve about $0.9 \times 10^{12}$ Btu/year or about $0.03 \%$ of the energy used to refine petroleum.

Improvements in energy use of catalytic crackers, relative to the energy requirements for a large new refinery, indicate a substantial potential for energy conservation. Presumably required would be the use heat-recovery equipment like heat exchangers, air preheaters, CO boilers, and turboexpanders. Potential savings of energy based on the previously tabulated information are about $20 \times 10^{13} \mathrm{Btu} /$ year, or $8.2 \%$ of the energy used to refine petroleum. However, because of the uncertainty in determining the comparative amount of energy used from burning the carbon during regeneration, it is impossible to specify what percentage of this total represents a feasible savings. For the summary of this report, three-fourths of this amount is used. Hydrocracking

Energy requirements clearly can vary considerably with the feed and product requirements. Literature information indicates a total requirement, excluding hydrogen, in the range of 240,000 to 400,000 $\mathrm{Btu} / \mathrm{bbl}$ of feed. The energy requirement for the moving-catalyst bed is the lowest reported, but whether or not this value is actually because of this process characteristic is unclear. Althouth the reactions are 
exothermic (55 to $70 \mathrm{Btu} / \mathrm{scf}$ of hydrogen absorbed), fuel is used to heat the hydrogen and feed streams. Heat is absorbed by the cold recycle gases and liquids, and heat exchange is used within the process. Energy is also required to pump the feed and products and to compress the hydrogen - this usage is equated to the electrical requirement. Sometimes steam is used for stripping in the fractionator section. In the following estimate, energy for manufacturing hydrogen used in the hydrocracker is based on a consumption and recycle of 1750 and 12,000 scf of hydrogen per barrel of feed respectively. In the hydrogen manufacturing process fuel is required to heat the feed and electricity is required to drive the pumps and compressors; it is assumed that steam is furnished by a waste-heat boiler at a "break-even" condition. Approximate energy requirements for hydrocracking, with and without energy required for the hydrogen consumed, are as follows:

\begin{tabular}{|c|c|c|c|}
\hline & $\begin{array}{l}\text { Energy requirement } \\
\quad(\mathrm{Btu} / \mathrm{bb1} \text { feed })\end{array}$ & $\frac{\text { Process }}{\left({ }^{\circ} \mathrm{C}\right)}$ & $\frac{\text { temperature }}{\left({ }^{\circ} \mathrm{F}\right)}$ \\
\hline \multicolumn{4}{|l|}{ Electricity ${ }^{a}$} \\
\hline Hydrocracking & 100,000 & & \\
\hline Hydrogen & 19,000 & & \\
\hline \multicolumn{4}{|l|}{ Fuel } \\
\hline Hydrocracking & 200,000 & 380 & 716 \\
\hline Hydrogen & 388,000 & & \\
\hline \multicolumn{4}{|l|}{ Steam } \\
\hline Hydrocracking & 13,000 & 260 & 500 \\
\hline \multicolumn{4}{|l|}{ Subtotal } \\
\hline Hydrocracking & 313,000 & & \\
\hline Hydrogen & 407,000 & & \\
\hline TOTAL & 720,000 & & \\
\hline
\end{tabular}

a Pumps and compressors electrically driven. Electricity converted to energy requirement based on $10,000 \mathrm{Btu} / \mathrm{kWhr}$. 
This tabulation assumes electric drives for the pumps and compressors, used mainly to compress the hydrogen. Some of this energy could be supplied from engines, turbines, or turboexpanders.

Hydrocracking is an energy-intensive process that converts most of the heavier portion of petroleum into more valuable, lighter materials. A large portion of the total energy demand is used to produce the hydrogen consumed in the process. Thus a judgment is made after weighing the utilization of the crude oil against the overall market for the many refinery products. A mitigating effect is the concurrent sulfur and nitrogen removal accomplished by the process.

At least seven variations of hydrocracker units exist. The main process difference is the fixed-bed vs the moving-catalyst-bed concepts, and whether or not this difference has a significant effect on energy consumption is unclear. Moving-catalyst units do not require elaborate "quench" systems, but they must maintain the catalyst and the feed in a fluidized condition. They also keep the catalyst in an active state by continuous withdrawal of spend catalyst and replacement with fresh catalyst. This practice not only avoids accumulation of solids on the catalyst, an occurrence which would result in plugging of the fixed-bed units, but also allows the catalyst to be more effective. Even though one small moving-catalyst-bed unit has been in operation for 12 years, this type of process has not been widely accepted; only one other U. S. unit and three foreign units are reported to exist. ${ }^{12}$

Potential savings of energy, with and without hydrogen manufacturing, are estimated for the 1974 processing rate as follows: 


\begin{tabular}{|c|c|c|}
\hline \multirow{2}{*}{ Conservation Measure } & \multicolumn{2}{|c|}{$\begin{array}{c}\text { Savings } \\
\text { (Btu/bbl feed) }\end{array}$} \\
\hline & Without $\mathrm{H}_{2}$ & With $\mathrm{H}_{2}$ \\
\hline $\begin{array}{l}\text { Better furnace design and control and } \\
\text { more use of heat recovery ( } 10 \% \text { of } \\
\text { consumption) }\end{array}$ & 0.5 & 1.4 \\
\hline $\begin{array}{l}\text { Recovery and use of one-fourth of the } \\
\text { low-grade heat rejected by air- and } \\
\text { water-cooled heat exchangers }\end{array}$ & 2.0 & 3.5 \\
\hline $\begin{array}{l}\text { Use of hydraulic turbines and more } \\
\text { efficient energy systems, e.g., } \\
\text { turbines using the discharge as } \\
\text { useful energy (one-fifth of } \\
\text { electrical energy) }\end{array}$ & 0.5 & 0.5 \\
\hline TOTAL & 3.0 & 5.4 \\
\hline
\end{tabular}

Not including conservation relative to hydrogen manufacture, this is $0.9 \%$ of the energy for refining petroleum; with hydrogen manufacture included, it is $1.7 \%$.

\section{Catalytic Reforming}

Energy requirements for catalytic reforming consist of fuel to heat the feed and recycled hydrogen and energy to pump the feed, recycled hydrogen, and coolants. Feed and hydrogen entering the reactors must be at a temperature of 450 to $540^{\circ} \mathrm{C}\left(842\right.$ to $\left.1004^{\circ} \mathrm{F}\right)$ and, because the predominate reactions in the first two reactors are endotherm1c, heat must be added to the process stream between reactors. In the last reactor(s) the balance between endothermic and exothermic reactions is more equalized. The amount of hydrogen recycle depends on the required hydrogen-to-oil ratio. This ratio affects energy consumption because of the circulation and heating requirements shown in the following tabulation: 13 


$$
\begin{array}{lrrr}
\text { Hydrogen-to-oil mole ratio } & 6: 1 & 8: 1 & 10: 1 \\
\begin{array}{l}
\text { Charge heat } \\
\text { Btu/bbl feed }
\end{array} & 127,000 & 158,000 & 185,000 \\
\begin{array}{l}
\text { Compressor energy } \\
\text { Btu/bbl feed }
\end{array} & 29,000 & 38,000 & 48,000
\end{array}
$$

\begin{tabular}{|c|c|c|}
\hline & \multicolumn{2}{|c|}{$\begin{array}{l}\text { Energy requirement } \\
\text { (Btu/bbl feed) for: }\end{array}$} \\
\hline & Cyclic & Semiregenerative \\
\hline Electricity ${ }^{a}$ & 50,000 & 75,000 \\
\hline Fue1 & 280,000 & 355,000 \\
\hline TOTAL & 330,000 & 430,000 \\
\hline
\end{tabular}

Thus, semiregenerative units that must be operated at higher pressures and higher hydrogen-to-oil ratios in order to minimize carbon deposition on the catalyst, require more compressor energy and more charge heat. Approximate energy requirements for catalytic reforming are as follows:

Credit could be given for the hydrogen produced since it is useful as process hydrogen for catalytic cracking, hydrorefining, and hydrotreating. Because it relieves the need to manufacture some of the hydrogen used by these processes, it could be assigned the amount of energy that would be required to manufacture the hydrogen (estimates of this energy usage are given in this report's hydrocracking section). Applying this credit, encrgy rcquirements for catalytic reforming are as follows: 


\begin{tabular}{|c|c|c|}
\hline & $\begin{array}{r}\text { Energ } \\
\text { (Btu/ } \\
\text { Cyclic } \\
\end{array}$ & $\begin{array}{l}\text { equirement } \\
\text { feed) for: } \\
\text { Semiregenerative }\end{array}$ \\
\hline Electricity ${ }^{a}$ & 36,000 & 67,000 \\
\hline Fuel & 2,000 & 189,000 \\
\hline TOTAL & 38,000 & 256,000 \\
\hline
\end{tabular}

Two features of catalytic reformers affect energy consumption.

First, higher pressure and hydrogen-to-oil ratios of the semiregenerative units result in more energy consumption and less hydrogen production. Secondly, bimetallic catalysts allow operation at lower pressure, temperature, and hydrogen-to-oil ratios, resulting in an energy savings.

Potential savings of energy in the catalytic-reforming process are estimated for the 1974 processing rate, with and without credit for the excess hydrogen produced, as follows:

Savings
Conservation measure
$\frac{\left(10^{13} \text { Btu/year }\right)}{\text { Without } \mathrm{H}_{2} \text { credit With } \mathrm{H}_{2} \text { credit }}$

Conversion of semiregenerative units

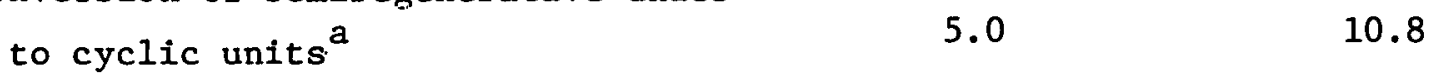

Better furnace design and control and

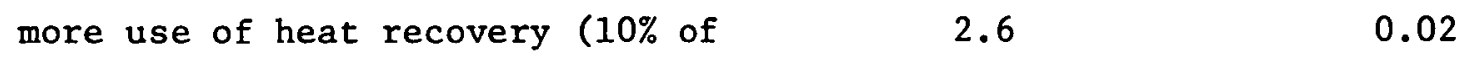
consumption) ${ }^{b}$

Recovery and use of one-fourth of the low-grade heat rejected by air- and $0.01 \quad 2.5$ water-cooled heat exchangers TOTAL 7.6 13.3

${ }^{a}$ Based on a savings of $100,000 \mathrm{Btu} / \mathrm{bbl}$ for conventional catalyst units and 50,000 Btu/bbl for bimetallic units.

$\mathrm{b}_{\text {On }}$ the basis of cyclic-unit consumption. 
Without credit for hydrogen, this savings is $2.4 \%$ of the energy used for refining petroleum; with credit for hydrogen, it is $4.2 \%$.

Catalytic Hydrorefining

Energy for catalytic hydrorefining is required to heat the mixed feed and the gas stream to the necessary reaction temperature and to pump and compress the fluids. Steam is used for stripping in some units, usually those processing a heavy residual feed. But because little of the capacity is operating on this type of feed, a negligible amount of steam is consumed. The total energy requirement, as reported in ref. 12, varies from 17,000 to $133,000 \mathrm{Btu} / \mathrm{bbl}$ of feed for gas-oil-type feed and as high as $270,000 \mathrm{Btu} / \mathrm{bb} 1$ of feed for a heavy residual feed.

Approximate energy requirements for catalytic hydrorefining with and without energy required for the manufacture of hydrogen are as follows:

\begin{tabular}{|c|c|c|c|}
\hline & $\begin{array}{l}\text { Energy requirement } \\
\quad(B t u / b b 1 \text { feed })\end{array}$ & $\frac{\text { Process }}{\left({ }^{\circ} \mathrm{C}\right)}$ & $\frac{\text { temperature }}{\left({ }^{\circ} \mathrm{F}\right)}$ \\
\hline $\begin{array}{l}\text { Electricity } \\
\text { Hydrorefining } \\
\text { Hydrogen }\end{array}$ & $\begin{array}{r}22,000 \\
8,000\end{array}$ & & \\
\hline $\begin{array}{l}\text { Fue } \perp \\
\text { Hydrorefining } \\
\text { Hydrogen }\end{array}$ & $\begin{array}{r}73,000 \\
155,000\end{array}$ & $\begin{array}{l}385 \\
900\end{array}$ & $\begin{array}{r}725 \\
1,650\end{array}$ \\
\hline $\begin{array}{l}\text { Subtotal } \\
\text { Hydroref1ning } \\
\text { Hydrogen } \\
\text { TOTAL }\end{array}$ & $\begin{array}{r}95,000 \\
160,000 \\
260,000\end{array}$ & & \\
\hline
\end{tabular}


The electricity requirement is for a relatively low pressure and low makeup-hydrogen rate; high pressure and high makeup-hydrogen could easily triple the requirement. Thus, to conserve energy, operation should be controlled at the lowest practical pressure and hydrogen conditions commensurate with a satisfactory product. The recycle-gas rate affects the fuel requirement as well as the compressor energy because the recycle gases must be heated.

It is doubtful that there are better process alternatives to accomplish the desired desulfurization and hydrogenation. Although chemical treatments can modify the form of the sulfur compounds, the treatments will not necessarily result in either separating the sulfur from the petroleum or in lowering the energy requirements. Some of the undesired components also might be removed by adsorbers. But in both of these processes the sulfur would not be extricated from the petroleum, causing reduced yields of the more desirable products.

Potential savings of energy in the catalytic-hydrorefining process are estimated for the 1974 processing rate as follows: 


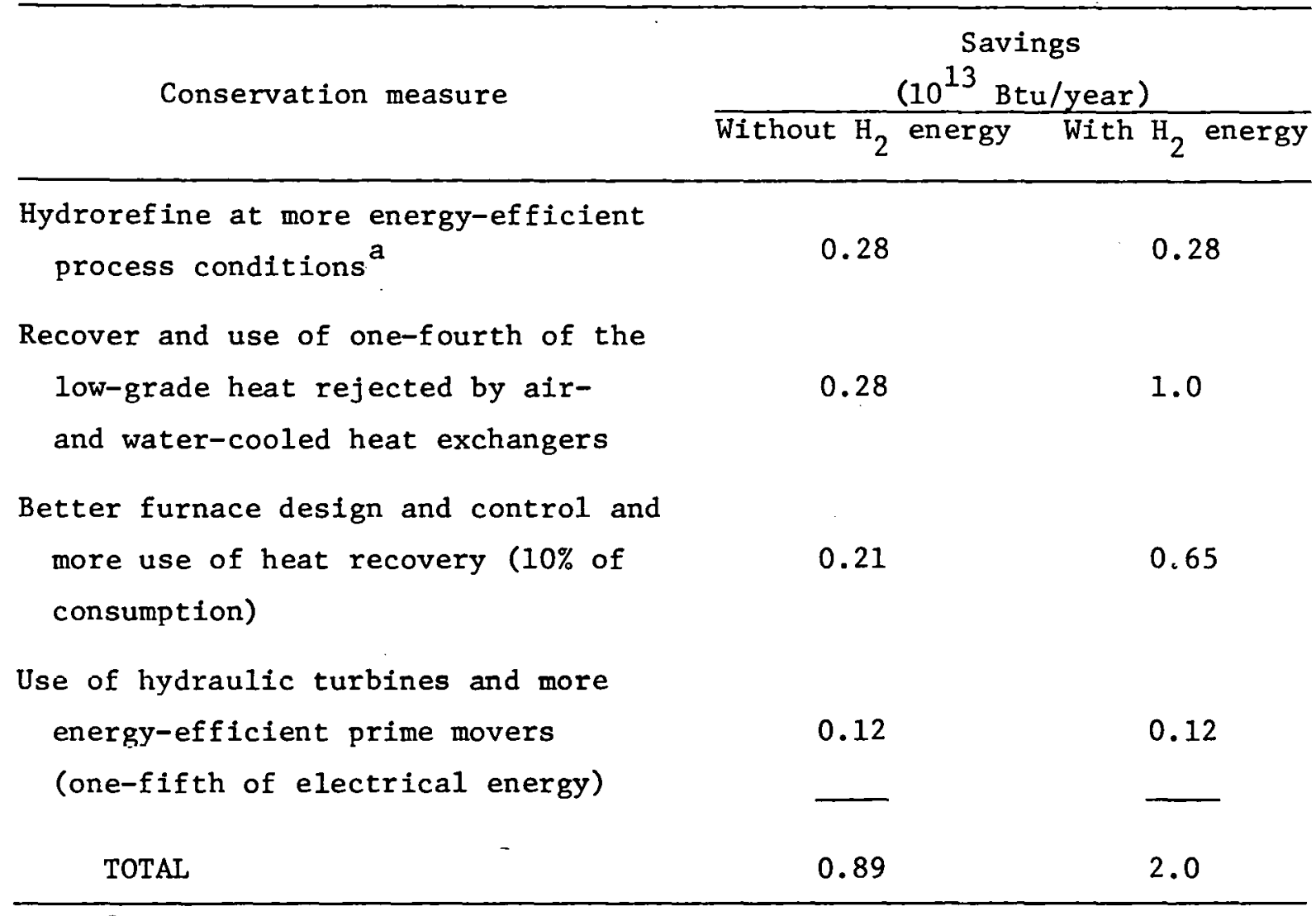

$a_{30 \%}$ of electricity on two-thirds of capacity and one-fourth of fuel used to heat the gases.

Not including conservation relative to hydrogen manufacture, this total is $0.3 \%$ of the energy for refining petroleum; with hydrogen manufacture included, it is $0.6 \%$.

\section{Catalytic Hydrotreating}

Energy for catalytic hydrotreating is required to heat the mixed feed and the gas stream to the necessary reaction temperature and to pump and compress the fluids. Steam is used for stripping in some units. Total energy requirements, as reported in ref. 12, vary from 28,000 to $110,000 \mathrm{Btu} / \mathrm{bbl}$ of feed. However, a comparison including energy for manufacturing hydrogen yields a larger difference which becomes yet greater when compared to the process which does not require makeup hydrogen. 
Approximate energy requirements for catalytic hydrotreating with and without energy required for the manufacture of hydrogen are as follows:

\begin{tabular}{|c|c|c|c|c|}
\hline & \multicolumn{2}{|c|}{$\begin{array}{c}\text { Energy requirement } \\
(\text { Btu/bbi feed })\end{array}$} & \multirow{2}{*}{$\frac{\text { Process }}{\left({ }^{\circ} \mathrm{C}\right)}$} & \multirow{2}{*}{$\frac{\text { temperature }}{\left({ }^{O} \mathrm{~F}\right)}$} \\
\hline & & & & \\
\hline $\begin{array}{l}\text { Electricity }{ }^{c} \\
\text { Hydrotreating } \\
\text { Hydrogen }\end{array}$ & $\begin{array}{r}14,000 \\
3,000\end{array}$ & 11,000 & & \\
\hline $\begin{array}{l}\text { Fuel } \\
\text { Hydrotreating } \\
\text { Hydrogen }\end{array}$ & $\begin{array}{l}39,000 \\
67,000\end{array}$ & 37,000 & $\begin{array}{l}260 \\
900\end{array}$ & $\begin{array}{r}500 \\
1,650\end{array}$ \\
\hline $\begin{array}{l}\text { Steam } \\
\text { Hydrotreating }\end{array}$ & 34,000 & 48,000 & 260 & 500 \\
\hline $\begin{array}{l}\text { Eubtotal } \\
\text { Hydrotreating } \\
\text { Hydrogen } \\
\text { TOTAL }\end{array}$ & $\begin{array}{r}87,000 \\
70,000 \\
160,000\end{array}$ & $\frac{96,000}{96,000}$ & & \\
\hline $\begin{array}{l}\text { BProcesses that } \\
\text { berocesses that } \\
\text { E Electricity co } \\
0,000 \text { Btu } / \mathrm{kWh} \text {. }\end{array}$ & $\begin{array}{l}\text { require } \\
\text { do not } \\
\text { nverted }\end{array}$ & $\begin{array}{l}\text { eup hy } \\
\text { ire me } \\
\text { nergy }\end{array}$ & hydro & $\begin{array}{l}\text { en. } \\
\text { based }\end{array}$ \\
\hline
\end{tabular}

The electricity requirement is for a relatively low pressure and low makeup-hydrogen rate. High pressure and high makeup-hydrogen could increase this requirement substantially. Thus, to conserve energy, operation should be controlled at the lowest practical pressure and hydrogen conditions commensurate with a satisfactory product. The recycle-gas rate affects the fuel requirement as well as the compressor energy because the recycle gases must be heated. 
Excluding the process which requires no makeup hydrogen, it is doubtful there are better process alternatives to accomplish the desired desulfurization. Although chemical treatments can modify the form of the sulfur compounds and absorbers might remove some of the undesireable components, the sulfur would not be extricated from the petroleum, causing reduced yields of the more desirable products.

Potential savings of energy in the catalytic-hydrotreating process are estimated for the 1974 processing rate as follows:

Conservation measure $\quad \frac{\left(10^{13} \text { Btu/year }\right)}{\text { Without } \mathrm{H}_{2} \text { energy With } \mathrm{H}_{2} \text { energy }}$

Hydrotreat at more energy-efficient process conditions ${ }^{a}$ 0.29

0.29

Recover and use of one-fourth of the low-grade heat rejected by air- and 1.1 2.5 water-cooled heat exchangers

Better furnace design and control and more use of heat recovery $(10 \%$ of 1.0 1.9 consumption)

Use of hydraulic turbines and more energyefficient prime movers (one-fifth of

electrical energy) TOTAL

\section{a}

$20 \%$ of electricity and one-fourth of fuel used to heat the gases on half of the feed.

Not including conservation relative to hydrogen manufacture, this total is $0.9 \%$ of the energy for refining petroleum; with hydrogen manufacture included, it is $1.6 \%$. 
As mentioned previously, one catalyt1c-hydrotreating process requires no makeup hydrogen. Excluding the energy for manufacturing hydrogen, the energy requirements for this process appear to be slightly higher than for the other catalytic-hydrotreating processes because of the gas-recycle rate. However, considering the energy required for the hydrogen, this process appears to use about $40 \%$ less energy. It is restricted to refining feeds wh1ch w111 generate sufficient hydrogen for the hydrogen-treating reactions, that is, reasonably high naphthene content and low olefin content. It also requires that process conditions be within a narrower range. ${ }^{13}$ Assuming that $15 \%$ of the feed to catalytichydrotreating processes could be treated by this process requiring no makeup hydrogen, the energy savings for the 1974 processing rate are estimated to be $1.2 \times 10^{13} \mathrm{Btu} /$ year or $0.4 \%$ of the energy used to refine petroleum.

\section{Alkylation}

Energy for alkylation units is required to pump the feeds, recycle, products, and coolant water; to run air-cooled heat-exchanger fans; to operate the refrigerant compressor for $\mathrm{H}_{2} \mathrm{SO}_{4}$ units; and to heat the reboilers of the fractionation columns. Most of the energy used by the alkylation process is for rebollers. HF units also use reboller heat in the HF stripper. A less but substantial usage of energy is for the compressor $\left(\mathrm{H}_{2} \mathrm{SO}_{4}\right.$ process), requiring about $12 \%$ of the process energy. About $80 \%$ of the electricity reported here is for pumping the coolant water. Using electricity for the compressors would increase electricity usage and decrease the high-pressure steam requirement. 
The $\mathrm{H}_{2} \mathrm{SO}_{4}$ unit shown in Fig. B.14 of Appendix B illustrates using high-pressure steam to drive the compressor with the turbine exhaust being condensed in some of the heaters and reboilers.

The quantity of energy required for alkylation, especially for HFalkylation units, has not been well defined. Reference 14 information indicates that $\mathrm{HF}$ units use more energy than do $\mathrm{H}_{2} \mathrm{SO}_{4}$ units. However, one liscensor furnished information indicating just the opposite but pointed out that the energy varies depending on the particular application. Another liscensor of HF units would not furnish detailed information but also believed that $\mathrm{H}_{2} \mathrm{SO}_{4}$ units use more energy. Information from ref. 14 and the liscensor are given in the following tabulation:

\begin{tabular}{|c|c|c|c|c|c|c|c|}
\hline & \multicolumn{3}{|c|}{$\begin{array}{c}\text { Energy requirement } \\
\text { (Btu/bb1 product) }\end{array}$} & \multicolumn{4}{|c|}{$\frac{\text { Process temperature }}{\mathrm{H}_{2} \mathrm{SO}_{4}}$} \\
\hline & $\mathrm{H}_{2} \mathrm{SO}_{4}$ & $\mathrm{HF}^{\mathrm{a}}$ & $\mathrm{HF}$ & $\left({ }^{\circ} \mathrm{C}\right)$ & $\frac{4}{\left({ }^{O} F\right)}$ & $\left({ }^{\mathrm{O}} \mathrm{C}\right)$ & $\left({ }^{\circ} \mathrm{F}\right)$ \\
\hline Electricity & 48,000 & 37,000 & 15,000 & & & & \\
\hline Fue1 & 160,000 & $1,040,000$ & 13,000 & 260 & 500 & 260 & 500 \\
\hline Steam & $\underline{520,000}$ & 15,000 & $370,000^{c}$ & 399 & 750 & 260 & 500 \\
\hline TOTAL & 730,000 & $1,100,000$ & 400,000 & & & & \\
\hline
\end{tabular}

a Source: R. E. Payne, AlkyZation - What You Should Know About This Process, Petroleum Refiner, Vol. 37 (9), Gulf Publishing Company, Houston, Tex., September 1958. $\mathrm{Btu} / \mathrm{kWhr}$.

$b_{\text {Electricity converted to energy requirement based on } 10,000}$

${ }^{c}$ Could be obtained from direct firing or from hot ofl.

Polymerization is an alternate process to upgrade the octane rating of fuels. However, alkylation has some basic advantages in that product yield is higher because the isobutane as well as the olefins are converted 
and the alkylate is free of gum-forming materials. Thus alkylation is expected to continue as an important refining process as long as there is a demand for high-octane fuel.

Based on ref. 14 energy requirements given in the previous tabulation, substitution of the $\mathrm{H}_{2} \mathrm{SO}_{4}$ process for $\mathrm{HF}$ alkylation indicates a potential energy savings of $14 \%$ of the energy used for alkylation. However, as discussed previously, HF process liscensors believe the HF process to be less energy-intensive. The fractionation equipment is essentially the same for both acid-catalyzed processes. Thus substitution would consist primarily of modifying or replacing the reactor section. Energy requirements for the refrigerant compressors of the $\mathrm{H}_{2} \mathrm{SO}_{4}$ units appear to be considerably higher than the energy required for the watercoolant and HF-stripper systems of the HF units. Thus the energy savings given here are based on estimates of this difference and assume that the energy for pumping the process streams and for fractionation are the same for both processes. The energy savings resulting from replacing half of the $\mathrm{H}_{2} \mathrm{SU}_{4}$ capacity with the $\mathrm{HF}$ process would be $0.6 \times 10^{13}$ $\mathrm{Btu} /$ year or $0.2 \%$ of the energy used to refine petroleum.

The potential for other energy savings in the alkylation process are estimated for the 1974 processing rate, using the energy requirement data furnished by the liscensor, as follows: 


\begin{tabular}{lc}
\hline & \multicolumn{1}{c}{ Conservation measure } \\
\hline $\begin{array}{l}\text { Better furnace design and control and } \\
\text { more use of heat recovery (10\% of } \\
\text { consumption) }\end{array}$ & $\left(10^{13}\right.$ Btu/year $)$ \\
$\begin{array}{l}\text { Recovery and use of one-fourth of the } \\
\text { low-grade heat rejected by air- and } \\
\text { water-cooled heat exchangers }\end{array}$ & 0.23 \\
\hline Total & 1.0 \\
\hline
\end{tabular}

This total is about $0.4 \%$ of the energy used to refine petroleum. If half of the $\mathrm{H}_{2} \mathrm{SO}_{4}$ process capacity were converted to $\mathrm{HF}$ units and the other measures were taken. the savings would increase by $0.2 \%$ to $0.6 \%$ of the energy used to refine petroleum.

\section{Isomerization}

Energy for isomerization is required to pump the feed, recycle, products, and coolant water; to run the air-cooled heat-exchanger fans; and to heat the feed and reboiler streams. For the butane isomerization units the energy required for the fractionator is disregarded here because these requirements are included in the alkylation unit for which the isobutane is being made. Therefore, for butane isomerization only the energy associated with the reactor and stabilizer is given. Energy for $\mathrm{C}_{5} / \mathrm{C}_{6}$ isomerization includes the deisopentanizer requirement. Approximate energy requirements for isomerization are as follows: 


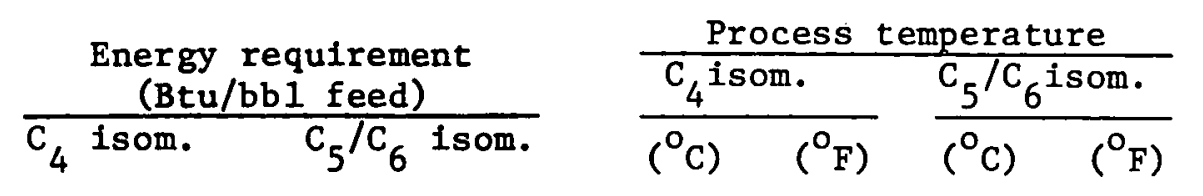

\begin{tabular}{|c|c|c|c|c|c|c|}
\hline Electricity ${ }^{a}$ & 12,000 & 15,000 & & & & \\
\hline Fue1 & 32,000 & 42,000 & $177^{\circ}$ & 350 & 260 & 500 \\
\hline Steam & $\underline{23,000}$ & 45,300 & 260 & 500 & 260 & 500 \\
\hline TOTAL & 67,000 & 102,000 & & & & \\
\hline
\end{tabular}
$\mathrm{Btu} / \mathrm{kWhr}$.

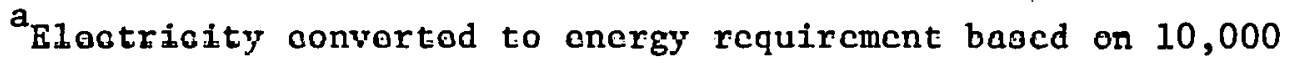

No apparent substitute exists for the conventional isomerization processes. The extent of its use clearly depends on factors such as the demand for high-octane components with these boiling characteristics and the demand for the materials used in petrochemical feedstock.

Potential savings of energy in the isomerization process are estimated for the 1974 processing rate as follows:

\begin{tabular}{|c|c|c|}
\hline \multirow{3}{*}{ Conservation measure } & \multicolumn{2}{|c|}{ Säviligs } \\
\hline & $\left(10^{13}\right.$ & Btu/year) \\
\hline & $\mathrm{C}_{4}$ isom. & $\mathrm{C}_{5} / \mathrm{C}_{6}$ isom. \\
\hline $\begin{array}{l}\text { Better furnace design and control and } \\
\text { more use of heat recovery (10\% of } \\
\text { consumption) }\end{array}$ & 0.010 & 0.012 \\
\hline $\begin{array}{l}\text { Recovery and use of one-fourth of the } \\
\text { low-grade heat rejected by air- and } \\
\text { water-cooled heat exchangers }\end{array}$ & 0.019 & 0.023 \\
\hline TOTAL & 0.029 & 0.035 \\
\hline
\end{tabular}

These energy savings represent $0.02 \%$ ( $0.009 \%$ for $\mathrm{C}_{4}$ isomerization and $0.011 \%$ for $C_{5} / C_{6}$ isomerization) of the energy used to refine petroleum. 


\section{Polymerization}

Energy for polymerization units is required to pump the feeds, recycle, products, and coolant water, to run air-cooled heat-exchanger fans, and to heat the reboilers of the depropanizer and debutanizer columns. Although the reactions are exothermic and heat exchange is practiced, the process is quite energy intensive, largely because of the fractionation columns.

Energy requirements for polymerization based on information in ref. 15 are as follows:

\begin{tabular}{|c|c|c|c|}
\hline & $\begin{array}{l}\text { Energy requirement } \\
\text { (Btu/bbl product) }\end{array}$ & $\frac{\text { Process }}{\left({ }^{\circ} \mathrm{C}\right)}$ & $\frac{\text { temperature }}{\left({ }^{O} \mathrm{~F}\right)}$ \\
\hline Electricity & 48,000 & & \\
\hline Steam & 800,000 & 260 & 500 \\
\hline TOTAL & 850,000 & & \\
\hline
\end{tabular}

However, the utility requirements report by Nelson 3 are much less, about one-fourth as much.

Utility requirements for the liquid-phosphoric-acid process are not published, but the energy requirements probably are not significantly different from those for the solid-catalyst process.

Potential energy savings in the polymerization process are not estimated here because the extent of use of the process is small and unknown.

\section{Hydrogen Production}

Energy for manufacturing hydrogen by steam reforming is required to compress and pump process fluids and coolant water; to run air-cooled 
heat-exchanger:fans; and to heat the steam and feed gas. The amount of electricity required is very sensitive to the pressure at which the hydrogen leaves the plant, and the data presented in this report are representative of a plant delivering hydrogen at 150 psia. Steam requirements for the process are assumed to be on an internally-generated, break-even basis.

Approximate energy requirements for manufacturing hydrogen are as follows:

\begin{tabular}{lccc}
\hline & $\begin{array}{c}\text { Energy requirement } \\
\left(\mathrm{Btu} / 10^{13} \text { scf } \mathrm{H}_{2}\right)\end{array}$ & $\left.{ }^{\circ} \mathrm{C}\right)$ & $\left({ }^{\circ} \mathrm{F}\right)$ \\
\hline $\begin{array}{l}\text { Electricity } \\
\text { Fuel }\end{array}$ & 11,000 & & \\
TOTAL & 222,000 & 900 & 1,650 \\
\hline \multicolumn{4}{c}{${ }^{\mathrm{a}}$ Electricity is converted to energy requirement } \\
based on $10,000 \mathrm{Btu} / \mathrm{kWhr}$.
\end{tabular}

Potential savings of energy estimated for manufacturing hydrogen, based on the production rate suggested in this report tor 1914 (i.e., $480 \times 10^{6} \mathrm{scf} /$ day) are as follows:

\begin{tabular}{lc}
\hline \multicolumn{1}{c}{ Conservation measure } & $\begin{array}{c}\text { Savings } \\
\left(10^{13} \text { Btu/year) }\right.\end{array}$ \\
\hline $\begin{array}{l}\text { Better furnace design and control and } \\
\text { more use of heat recovery (10\% of } \\
\text { consumption) }\end{array}$ & 0.4 \\
$\begin{array}{l}\text { Recovery and use of one-fourth of the low- } \\
\text { grade heat rejected by air- and water- } \\
\text { cooled heat exchangers }\end{array}$ & 0.6 \\
\hline \\
TOTAL
\end{tabular}

This total is about $0.3 \%$ of the energy used for refining petroleum. 


\section{REFERENCES}

1. A. Cantrell, "Annual Refining Survey," Oil and Gas Journal, The Petroleum Publishing Company, Tulsa, Okla. (March 22, 1971; March 27, 1972; April 2, 1973; and April 1, 1974).

2. Stondard Industrial Classficiation Manual, Office of Management and Budget, 1972 .

3. W. L. Nelson, Guide to Refining Costs, 2nd ed., The Petroleum Publishing Company, Tulsa, Okla. (1970).

4. U.S. Department of Interior, Bureau of Mines, Petrolieum Refineries in the United States and Puerto Rice - January 1, 1974, Mineral Industry Surveys, Washington, D.C., July 22, 1974.

5. U.S. Department of the Interior, Bureau of Mines, Minerals Yearbook - Metals, Minerals, and Fuels, Vol. 1, Washington, D.C., 1970 and 1973.

6. U.S. Department of the Interior, Bureau of Mines, Mineral Industry Surveys, Crude Petroleum, Petroleum Products, and Natural-GasLiquids, Washington, D.C., 1962-1973 (final summaries) and April 1974 (monthly statement).

7. C. L. Brown and M. Kraus, "Air Preheaters Cut Costs and Increase Efficiency," Oil and Gas Journal, The Petroleum Publishing Company, Tulsa, Okla. (October 22, 1973).

8. R. D. Reed, "Fact and Fancy of Heater Efficiency," Oil and Gas Journal, The Petroleum Publishing Company, Tulsa, Okla. (April 2, 1973).

9. M. G. Whitcomb, Jr. and F. M. Orr, Plan Plant Energy Conservation, Hydrocarbon Processing, vol. 52 (7), Gulf Publishing Company, Houston, Tex., July 1973.

10. W. L. Nelson, Petrolezm Refining Engineering, McGraw-Hill Book Company, Inc., New York, 1949.

11. E. S. Monroe, "Vacuum Pumps Can Conserve Energy," Oil and Gas Joumal, The Petroleum Publishing Company, Tulsa, Okla. (February 3, 1975).

12. 1974 Refininf Process Handbook, Hydrocarbon Processing, vol. 53 (9), Gulf Publishing Company, Houston, Tex. September 1974.

13. G. D. Hobson, Modern Petrolezm TechnoZogy, 4th ed., John Wiley and Sons, New York, 1973. 
14. R. E. Payne, AlkyZation - What You Should Know About This Process, Petroleum Refiner, vol. 37 (9), Gulf Publishing Company, Houston, Tex. September 1958.

15. J. F. McMahon, C. Bednars, and E. Solomon, "Polymerization of Olefins as a Refinery Process," Advances in Petroleum Chemistry and Refining, vol. 7, Interscience Publishers, John Wiley and Sons, New York, 1963.

16. G. E. Congram, "Refiners Zero in on Better Desalting," Oil and Gas Joumal, The Petroleum Publishing Company, Tulsa, Okla. (December 30, 1974).

17. W. F. Bland and R. L. Davidson, Petroleum Processing Handbook, McGraw ll111 Book Company, Ine., New York, 1967.

18. R. Stiles, The Alkylation Process, Petrolezm Refiner, vol. 34 (2), Gulf Pullislifing Cumpairy, Hüustüi, Tex., Feliuary 1955.

19. 1966 Refining Process Handbook, Hydrocarbon Processing, vo1. 45 (9), Gulf Publishing Company, Houston, Tex., September 1966. 


\author{
APPENDIX A \\ Regional characteristics of energy consumption \\ in U. S. petroleum refineries \\ (based on ref. 6)
}

Notes:

Districts are identified by Fig. 5 of this report.

Steam conversion $-1333 \mathrm{Btu} / 1 \mathrm{~b}$.

Electricity conversion $-10,000 \mathrm{Btu} / \mathrm{kWhr}$.

Legend:

$$
\begin{aligned}
& \text { LFG - liquificd petroleum gas } \\
& \text { RG - refinery gas } \\
& \text { NG - natural gas } \\
& \text { PE1 - purchased electricity } \\
& \text { PSt - purchased steam }
\end{aligned}
$$




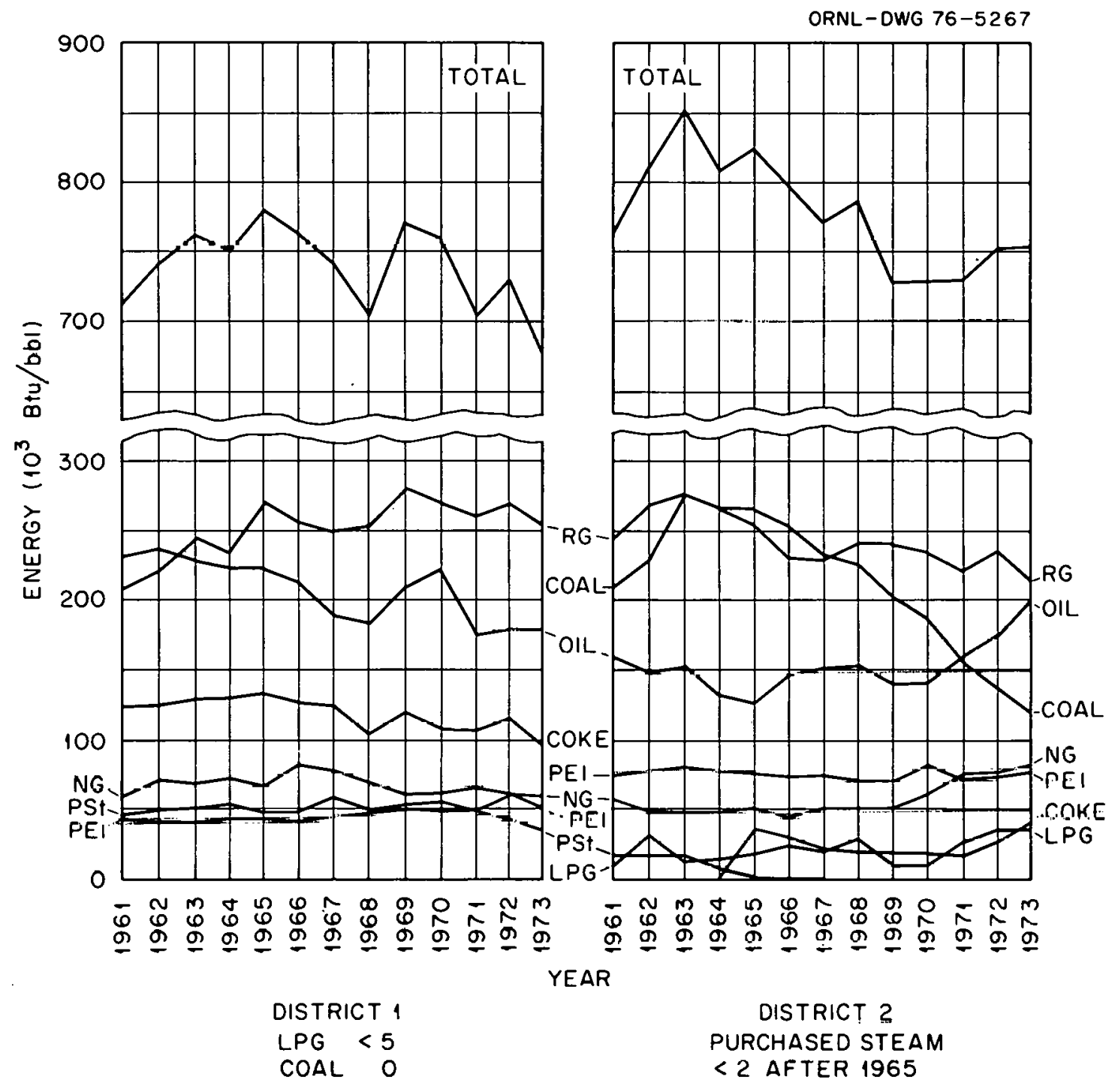

Fig. A.1. Energy consumption per barrel of crude oil in Bureau of Mines districts 1 and $2-1961-1973$. 


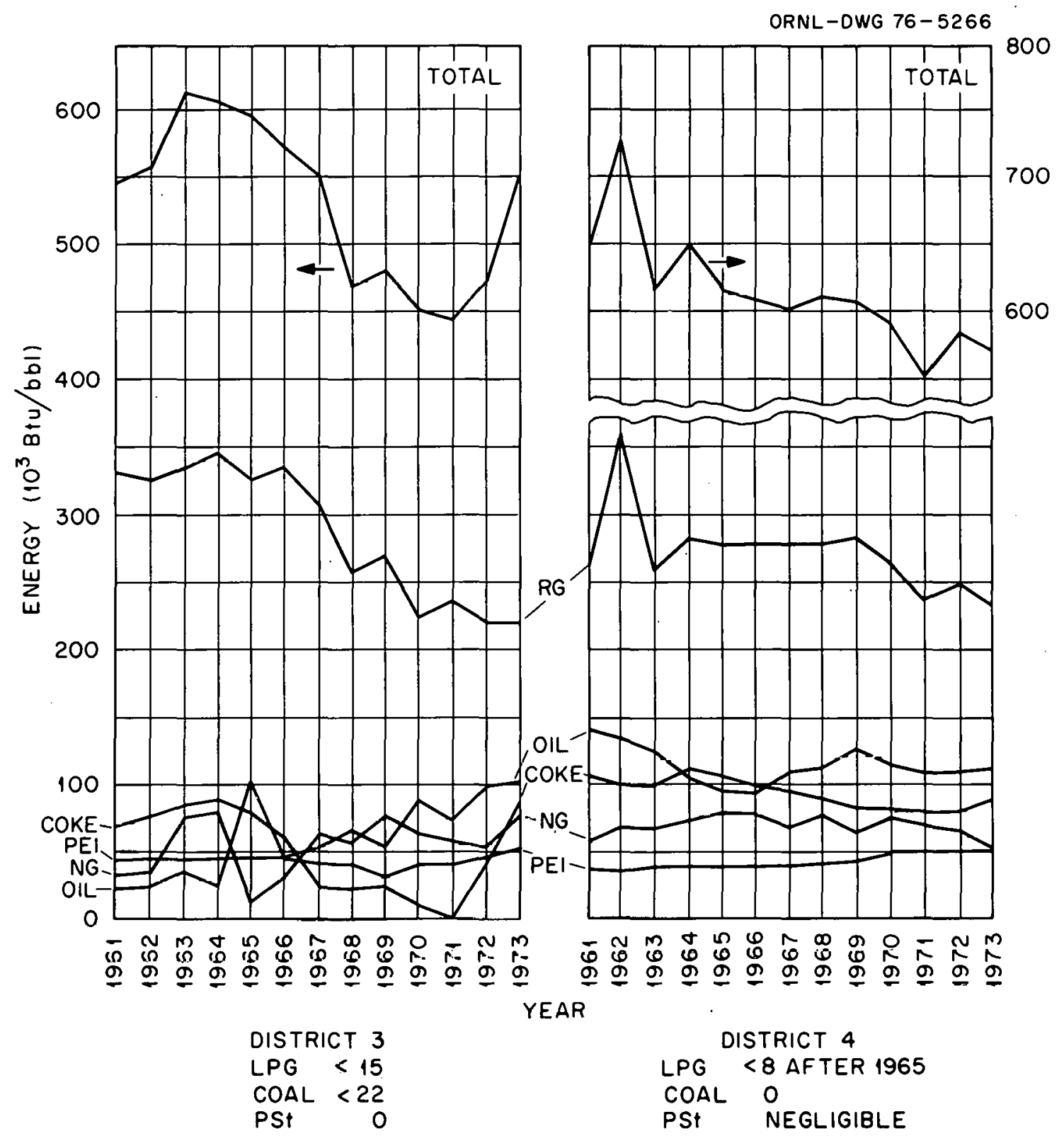

Fig. A.2. Energy consumption per barrel of crude oil in Bureau of Mines districts 3 and $4-1961-1973$. 


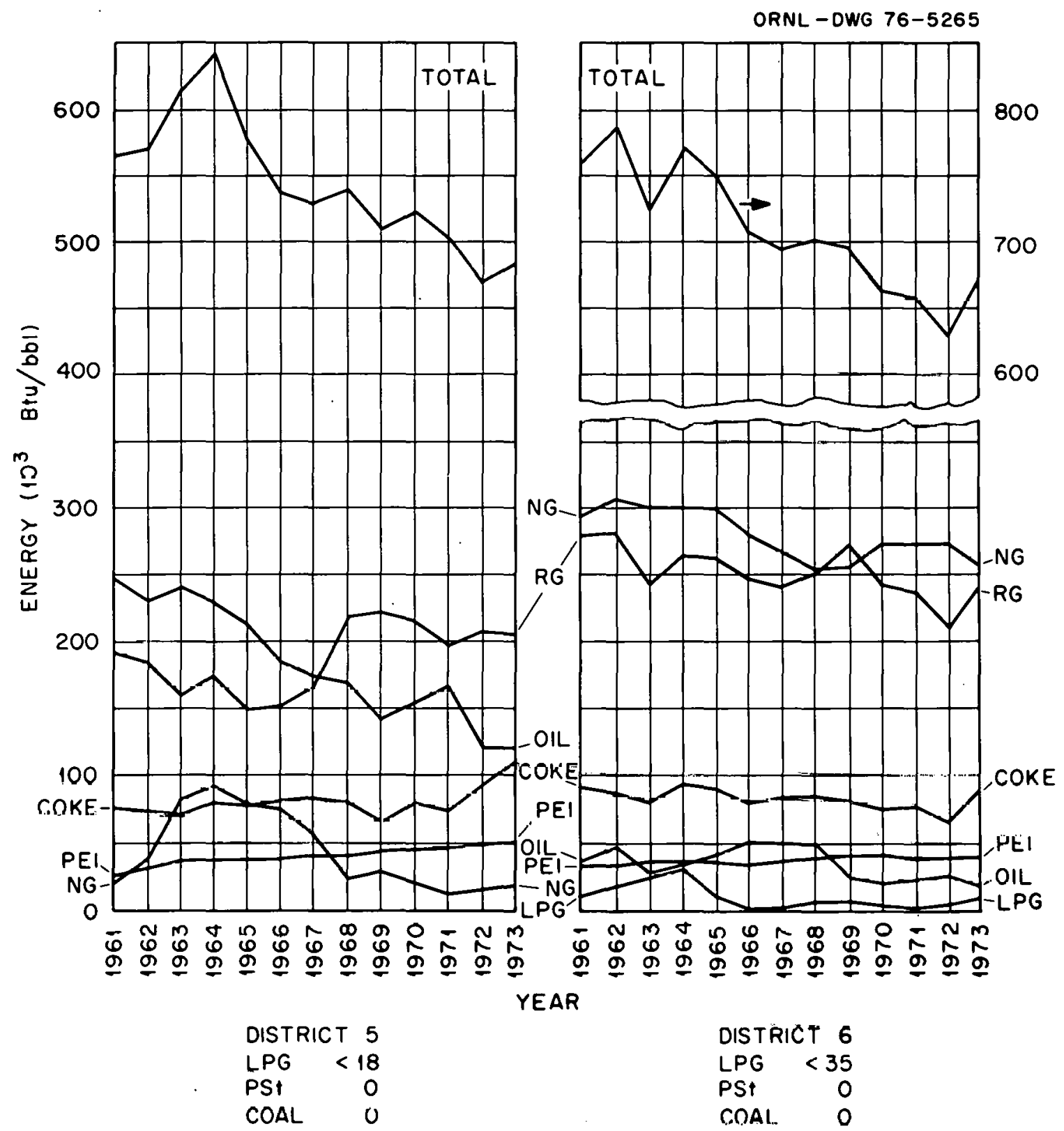

Fig. A.3. Energy consumption per barrel of crude o1l in Bureau of Mines districts 5 and $6-1961-1973$. 


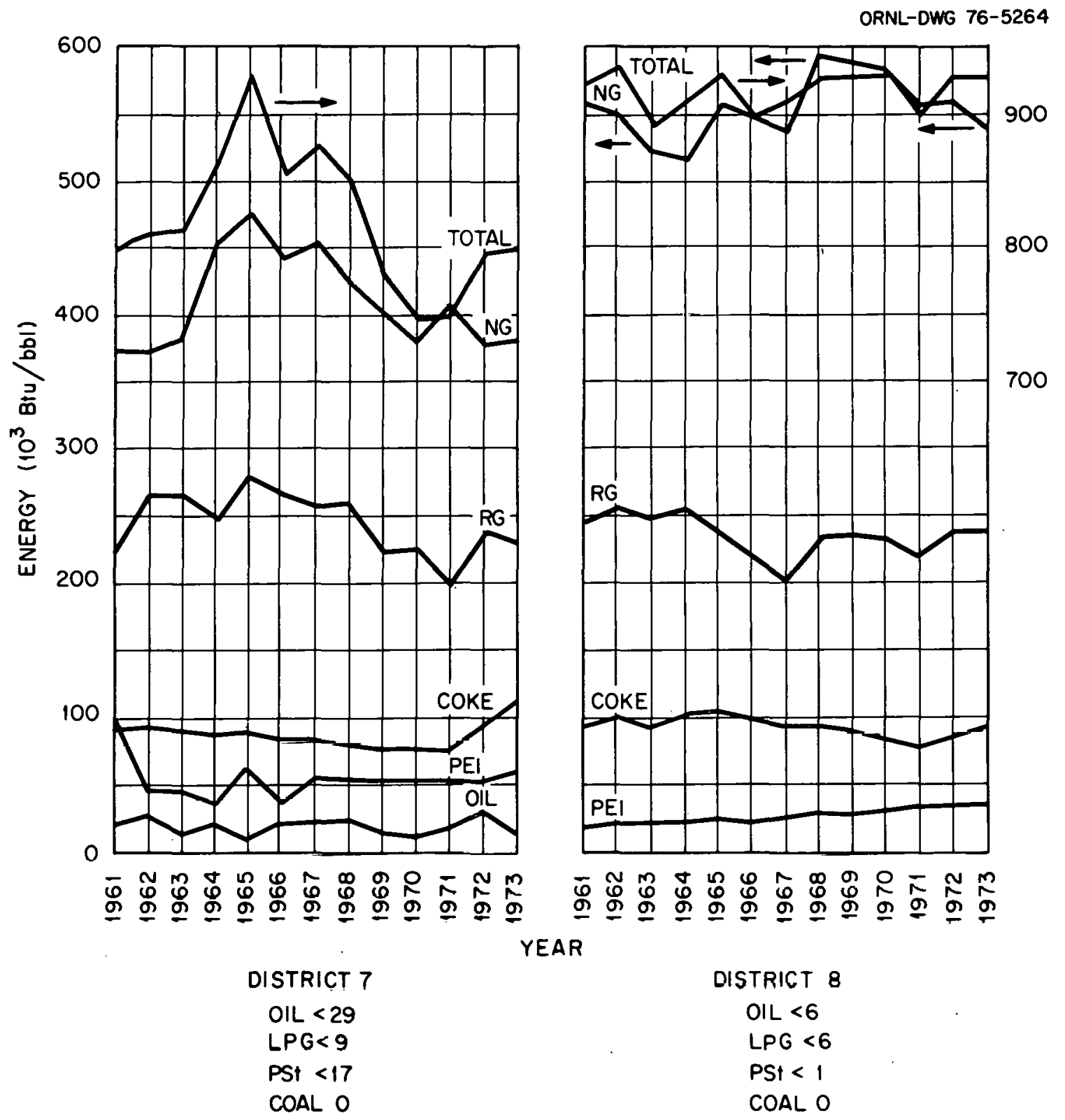

Fig. A.4. Energy consumption per barrel of crude oil in Bureau of Mines districts 7 and $8-1961-1973$. 


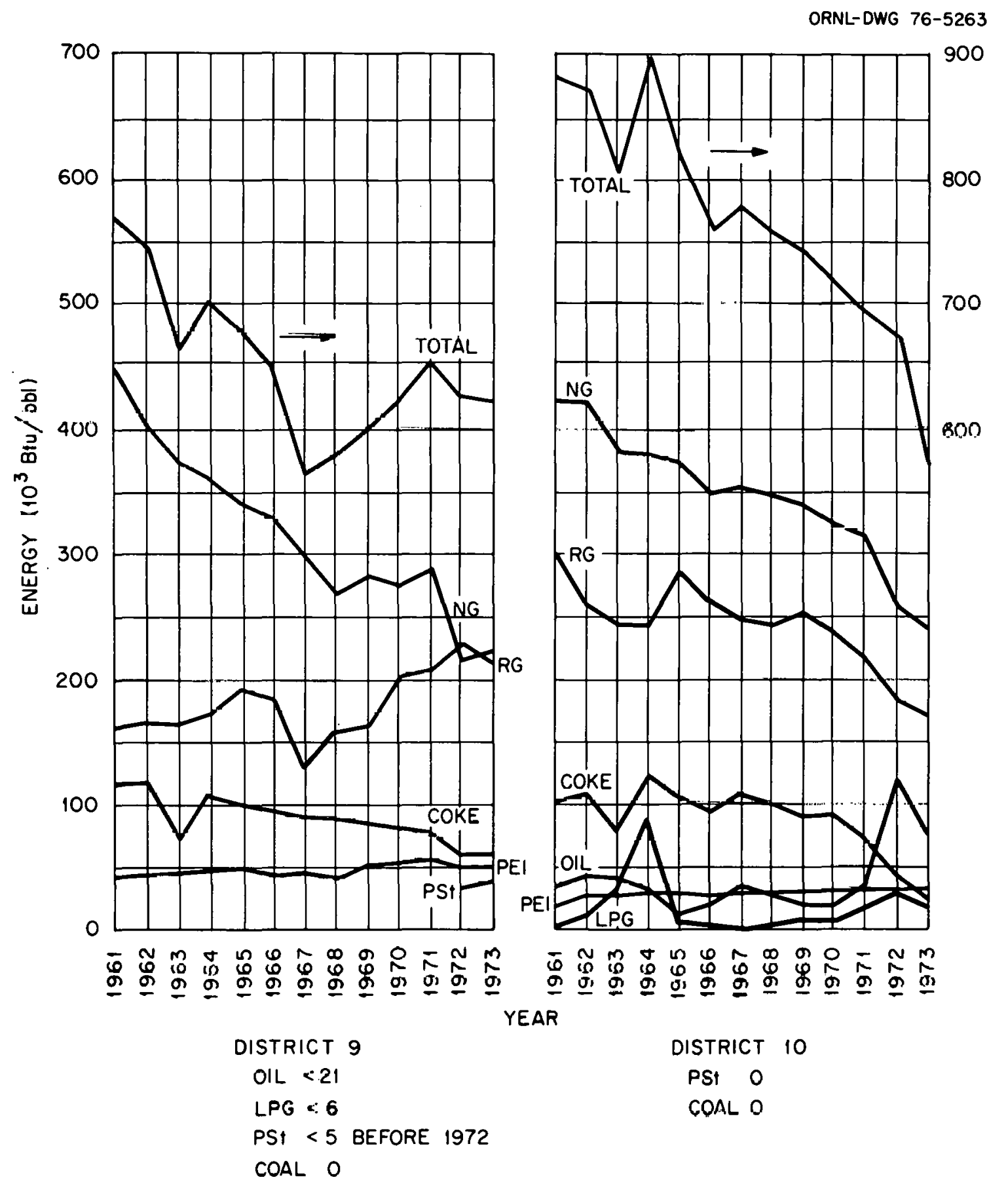

Fig. A.5. Energy consumption per barrel of crude oll in Bureau of Mines districts 9 and $10-1961-1973$. 


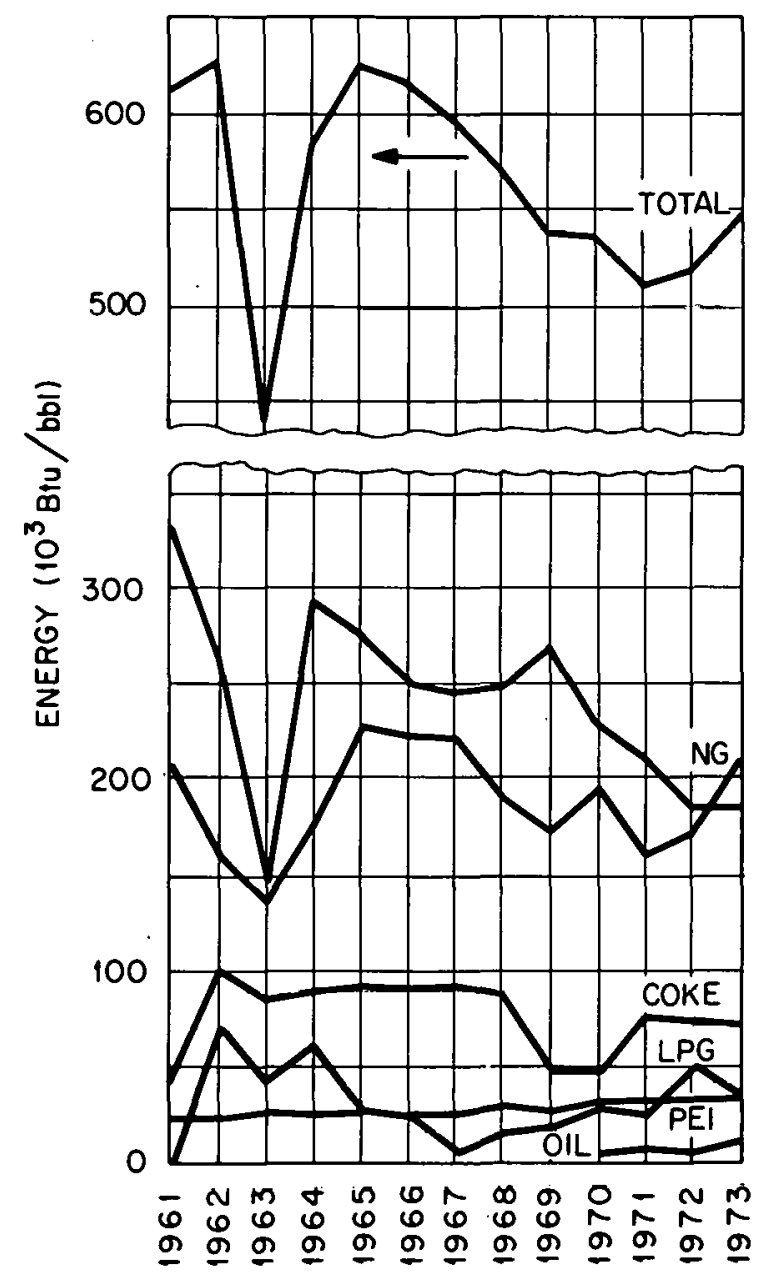

DISTRICT $\|$

OIL O BEFORE 1970

PS† 0

COAL O
ORNL-DWG

$76-5262$

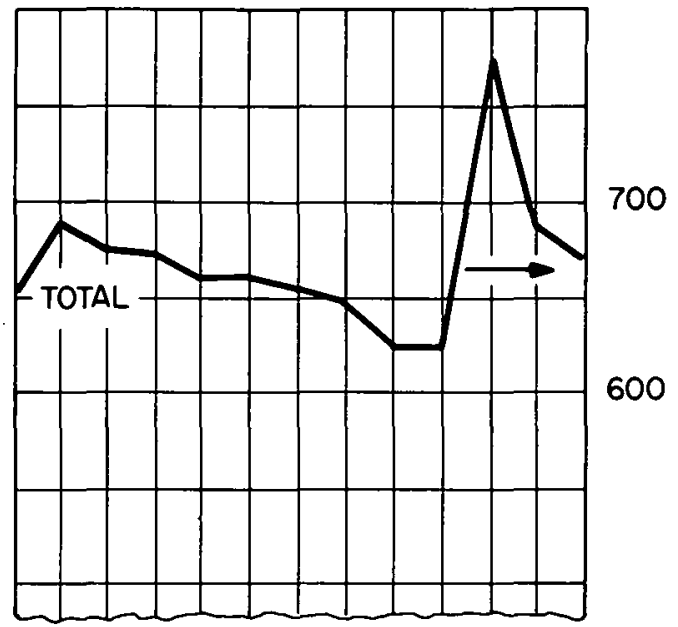

$R G$

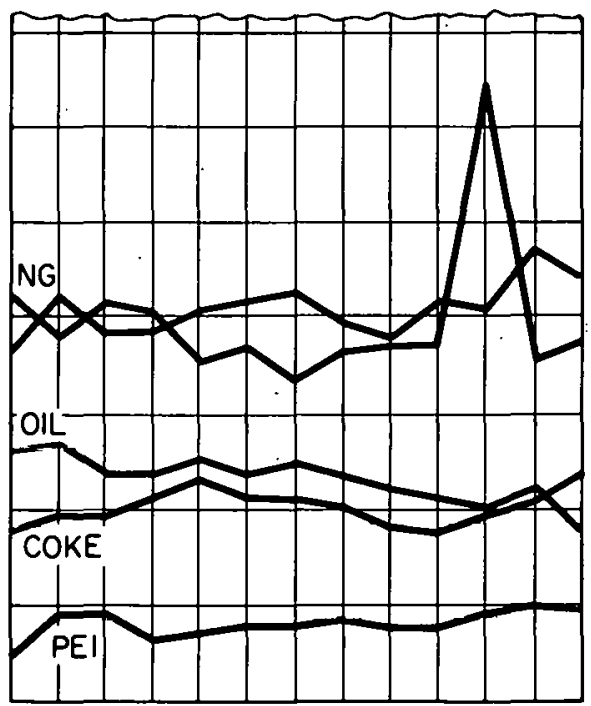

- $N$ m

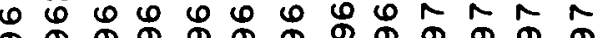

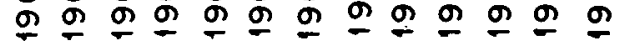
YEAR

Fig. A.6. Energy consumption per barrel of crude oll in Bureau of Mines districts 11 and $12-1961-1973$. 


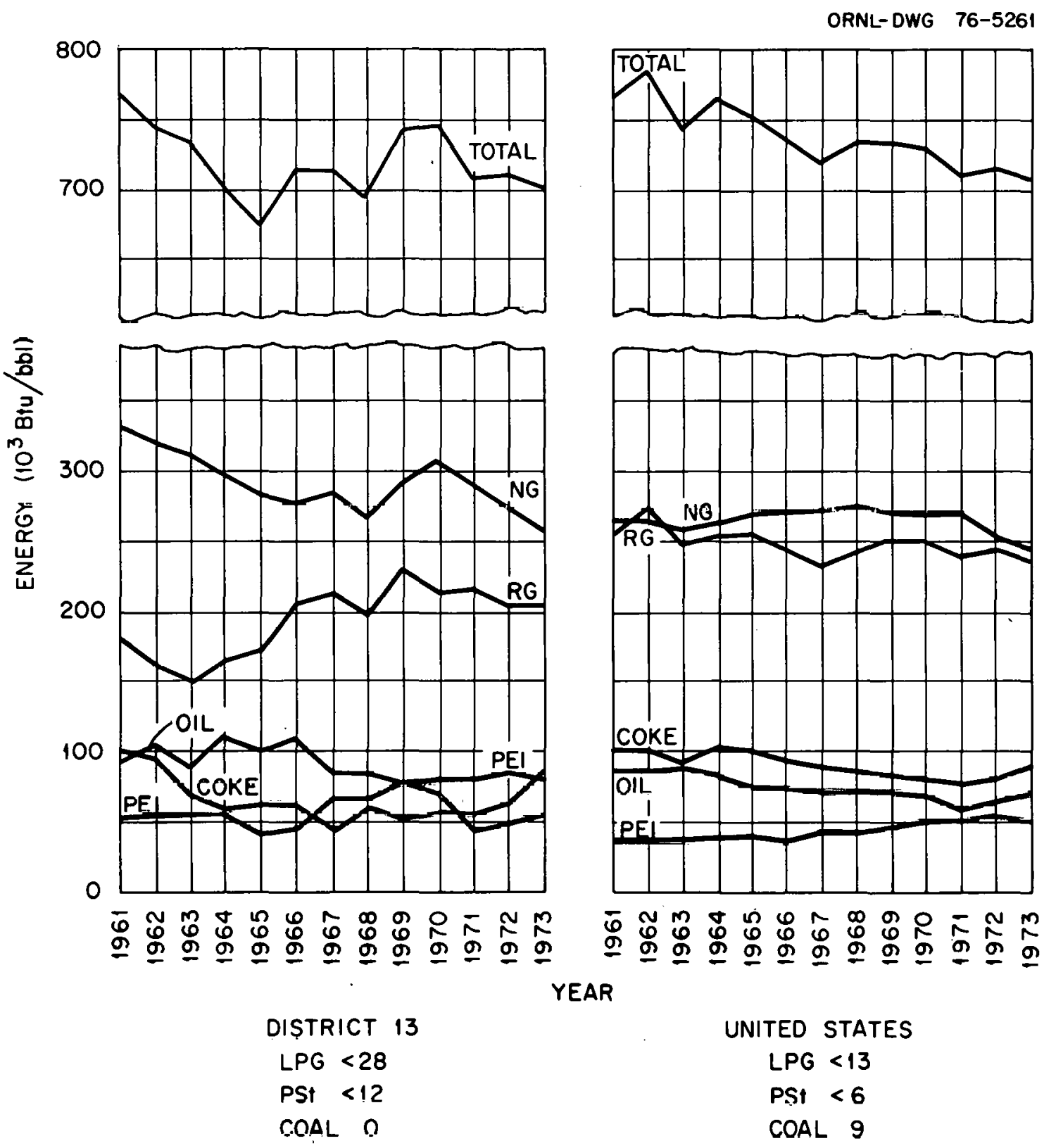

Fig. A.7. Energy consumption per barrel of crude oil in Bureau of Mines district 13 and the United States - 1961-1973. 


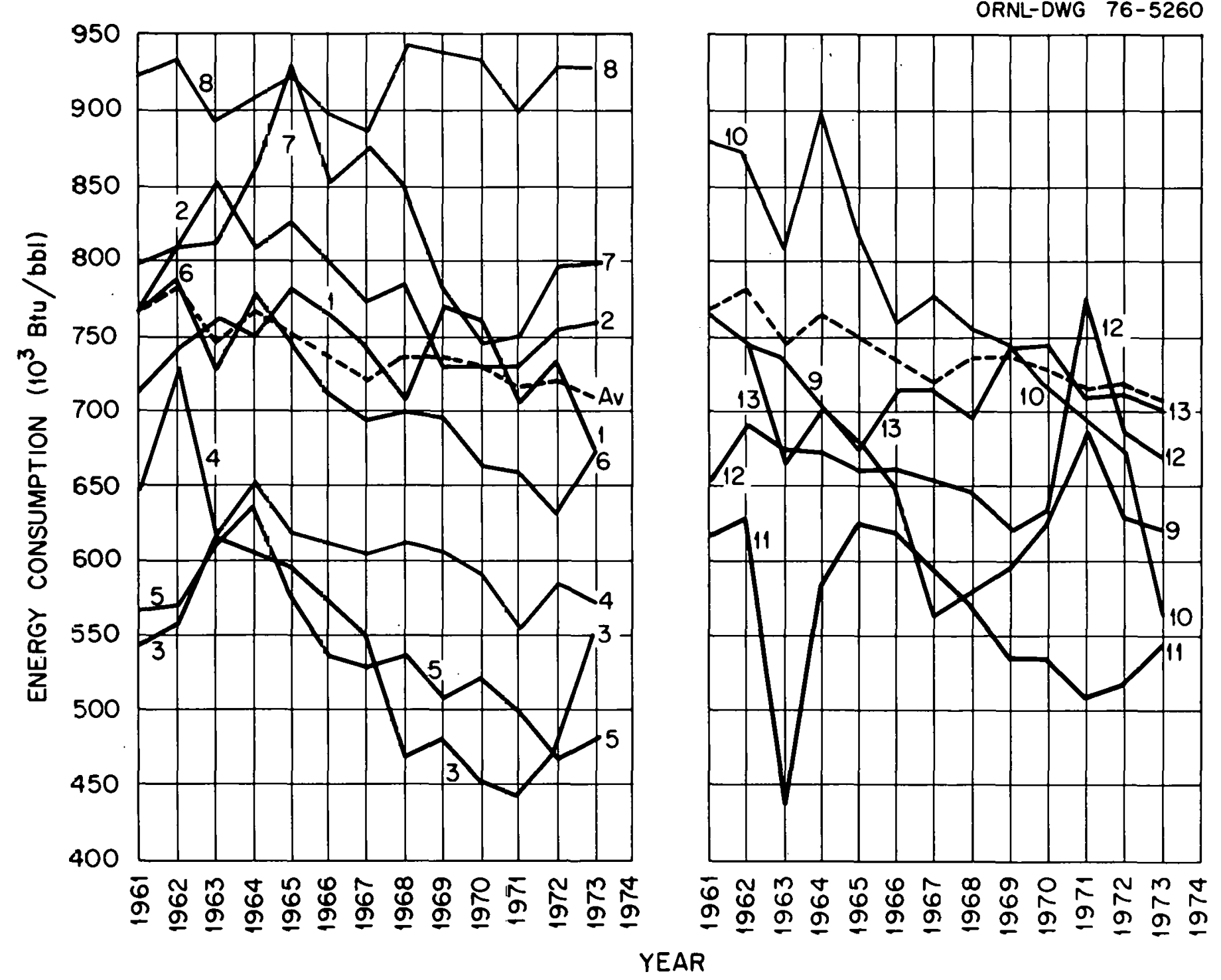

F1g. A.8. Energy consumpticn per barrel of crude oil in U.S. petroleum refinerles by Bureau of Mines districts - 1961-1973. 
THIS PAGE

WAS INTENTIONALLY

LEFT BLANK 
APPENDIX B

Petroleum refining process descriptions 


\section{Desalting}

Salts in the brine associated with crude oil accumulate as solids in the refinery-process equipment. They also contribute to the fouling of heat exchangers and to coke formation in pipe-still tubes. Furthermore, it is desirable to remove the chloride salts because they may convert to hydrochloric acid which corrodes the process equipment. Thus to prolong equipment life and to reduce maintenance and the frequency of "wash out" of equipment, desalting is performed to decrease the salt content to 10 to $15 \mathrm{lb}$ per $1000 \mathrm{bbl}$ of crude oil.

Representative salt content of crude oil varies from 20 to $60 \mathrm{1b} / 1000$ bb1 except for that of Mississippi mix which is $2201 \mathrm{~b} / 1000 \mathrm{bbl} .^{3}$

Table B.I gives the water requirement for a range of salt contents. ${ }^{3}$

Table B.1. Effect of salt content on water requirement

\begin{tabular}{lc}
$\begin{array}{c}\text { Salt content } \\
\left(1 \mathrm{~b} / 10^{3} \mathrm{bbl}\right)\end{array}$ & $\begin{array}{c}\text { Water requirement } \\
\text { (vol } \% \text { ot crude oil) }\end{array}$ \\
\hline 20 & 1 \\
100 & $2-5$ \\
200 & $4-10$ \\
500 & $10-25$ \\
1000 & $20-50$ \\
\hline Sourcct W. L. Ncloon; Cuido to Rofining Cooto; 3nd \\
ed., The Petroleum Publishing Company, Tulsa, Okla. (1970), \\
p.49.
\end{tabular}

Techniques for desalting consist of the following:

1. Addition of water to dilute the brine followed by settling in tanks. Desalting is promoted by heating to 93 to $143^{\circ} \mathrm{C}$ (200 to $300^{\circ} \mathrm{F}$ ) with adequate pressure. to prevent violent vaporization. 
2. Circulation through packed towers (sand, gravel, or excelsior) before or after settling.

3. Addition of caustic soda to a $\mathrm{pH}$ of 8-9.

4. High-potential electric fleld across the settling vessel $(16,000-33,000 \mathrm{~V})$ to promote separation by assisting in breaking the emulsion.

5. Addition of chemicals (i.e., surfactants and wetting agents). Figure B.1. illustrates a desalting system in which crude oil is heated to about $121^{\circ} \mathrm{C}\left(250^{\circ} \mathrm{F}\right)$ via heat exchange, mixed with water which has been warmed by the extracted brine, and separated from the brine in a settling tank. An electrostatic field is used to promote the separation by breaking the emulsion.

ORNL-DWG $76-8787$

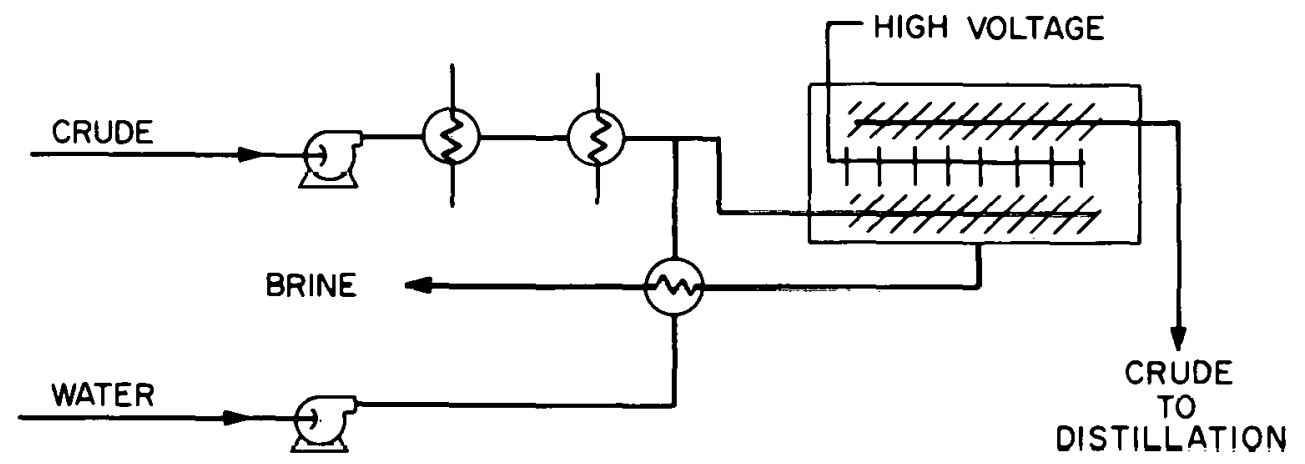

(3) PROCESS STREAM

Fig. B.1. Petroleum reftnery desalting system.

Realization of the importance of adequate desalting is stimulating Interest in better methods, such as two-stage electrostatic units, control of wash watcr, and mechanical-operational changes. 16 


\section{Atmospheric Distillation}

Following stabilization and desalting, if practiced, crude oil is separated into light distillates (gases, naphtha, and kerosine), gas oil, and residue. Each of these distillation products is processed further to provide usable products. Separation is accomplished by pumping crude oil through heat exchangers into a distillation column composed of a series of bubble-cap plates at a temperature high enough to separate the crude oil into its various fractions. Figure B.2. is a schematic diagram of an atmospheric-distillation system. Because the required temperature at atmospheric pressure often is high enough to decompose the crude oil, steam is injected into the tower to lower the required teed temperature to about 343 to $371^{\circ} \mathrm{C}\left(650\right.$ to $\left.700^{\circ} \mathrm{F}\right)$. Gases are withdrawn from the top of the column and the lighter liquid fractions are removed as side streams that are partially recycled through a stripper that may use steam. The heavier fraction is transferred for further processing such as vacuum distillation.

\section{Vacuum Distillation}

\section{General}

A common refinery practice is vacuum distillation of the residual from the atmospheric distillation tower to obtain heavy distillate suitable for cracking and for manufacturing lube oils. The bottoms from the vacuum tower may be used as asphalt, be coked, or be further cracked. As an overall average, vacuum-distillation capacity was $35 \%$ of crude-oil capacity in $1974 .^{1}$ Nearly all large refineries and about half of the small refineries perform vacuum distillation. Feed to the vacuum tower is heated to about $399^{\text {to }} 427^{\circ} \mathrm{C}\left(750\right.$ to $\left.800^{\circ} \mathrm{F}\right)$. Pressure in the tower is 
ORNL-DWG 76-8792

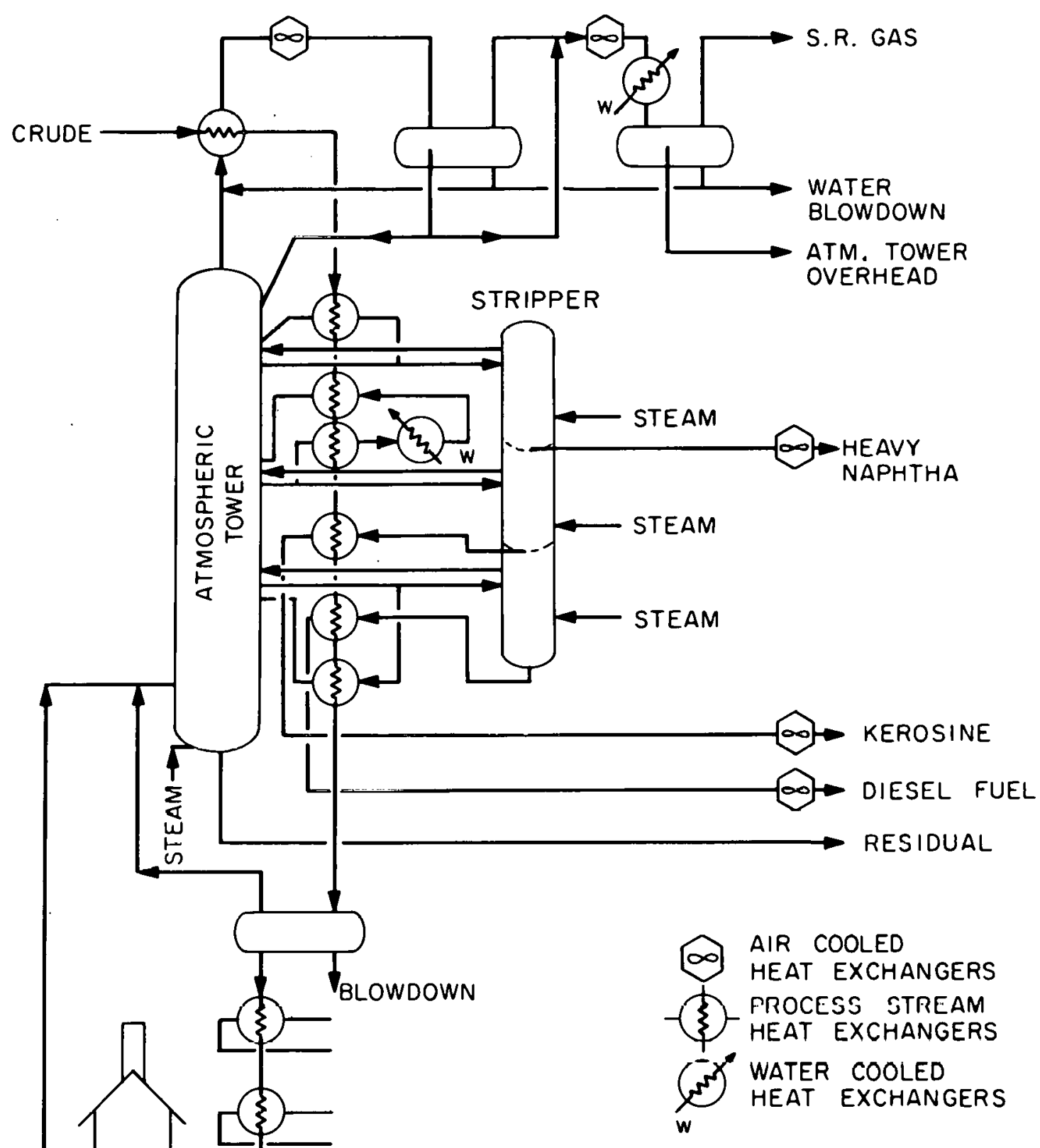

Fig. B.2. Single-stage crude oil distillation unit. 
maintained at about $75 \mathrm{~mm}$ of $\mathrm{Hg}$ with usually a condenser-steam ejector system. Although some refineries may use barometric condensers, these units are being replaced by water-cooled heat exchangers to reduce environmental pollution. Mechanical pumps could be used instead of steam jets but capital and maintenance costs would be much higher and there is concern about achieving a comparable reliability. Sometimes steam is also injected into the tower as a stripper.

Figure B.3. is a schematic diagram of a vacuum-distillation system. Gas Separation

The overhead fraction from the atmospheric tower is cooled to about $38^{\circ} \mathrm{C}\left(100^{\circ} \mathrm{F}\right)$ and transferred to tanks from which the straight-run gas and water are withdrawn. The remainder is transferred to fractionation towers to separate it into its components - propane, butane, and light and heavy gasoline. 'The fraction of the crude oil processed through saturate-gas-separation systems depends on the composition of the crude oil and on the refinery process. No industry average is available, but an example for a large modern refinery is that the feed would be about $10 \%$ of the crude oil. The temperature of the feed is raised by heat exchange and sometimes by steam reboilers.

Figure B.4. is a schematic diagram of a gas-separation system. Approximate pressures and temperatures in the towers are as follows:

\begin{tabular}{lcc} 
& Pressure (ps1g) & Temperature $\left({ }^{\circ} \mathrm{C} /{ }^{\circ} \mathrm{F}\right)$ \\
\hline Debutanizer & 175 & $177 / 350$ \\
Depropanizer & 300 & $121 / 250$ \\
Gasoline splitter & 30 & $132 / 270$ \\
\hline
\end{tabular}

Products are all cooled to about $100^{\circ} \mathrm{F}$. 


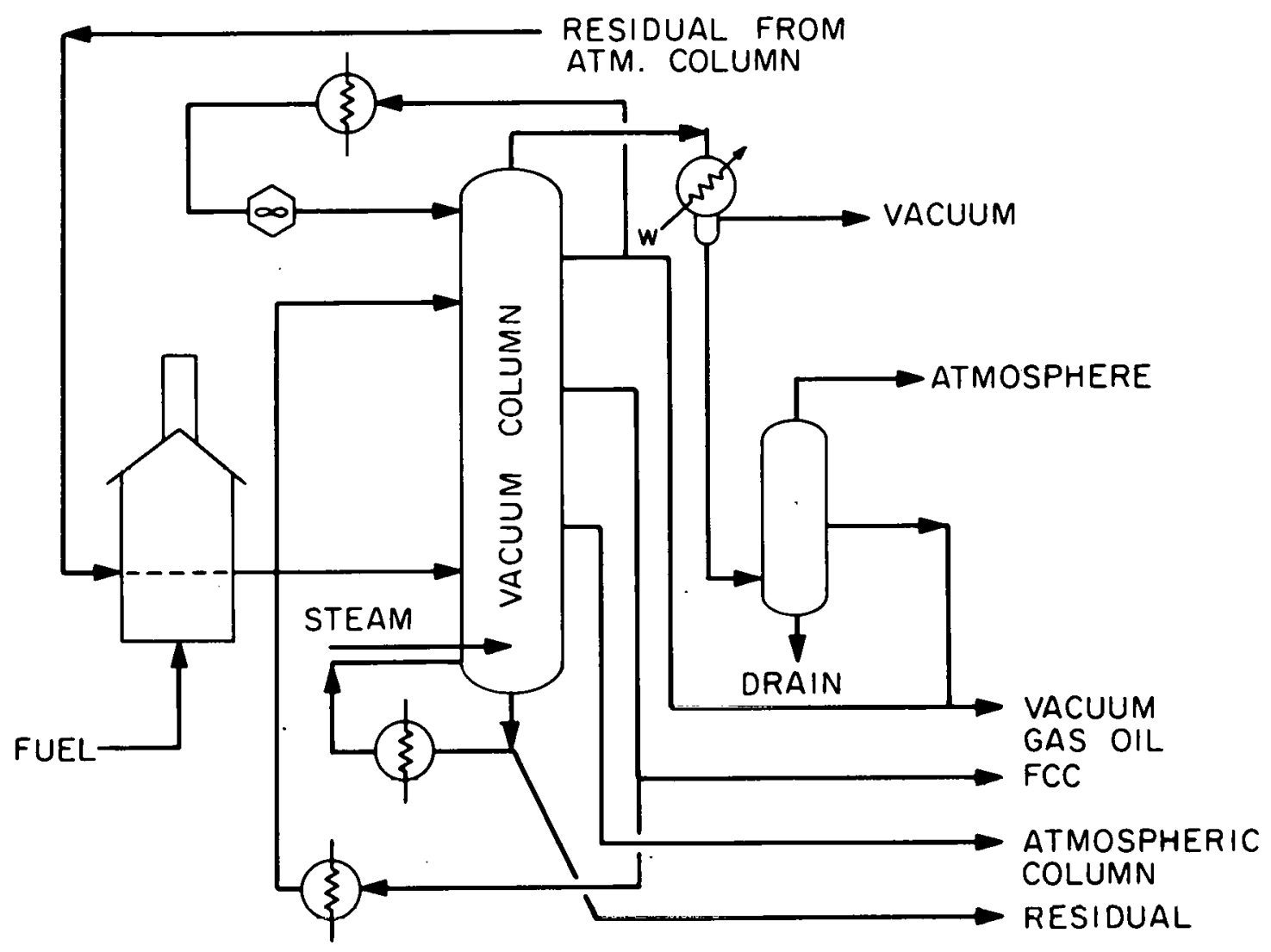

$\infty$ AIR coOled

$\infty$ HEAT EXCHANGER

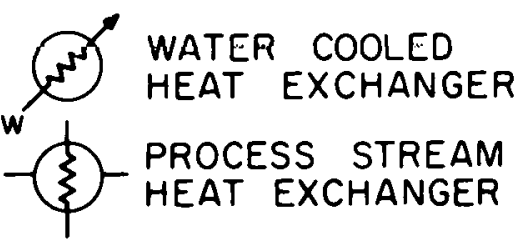

Fig. B.3. Vacuum-distillation unit. 


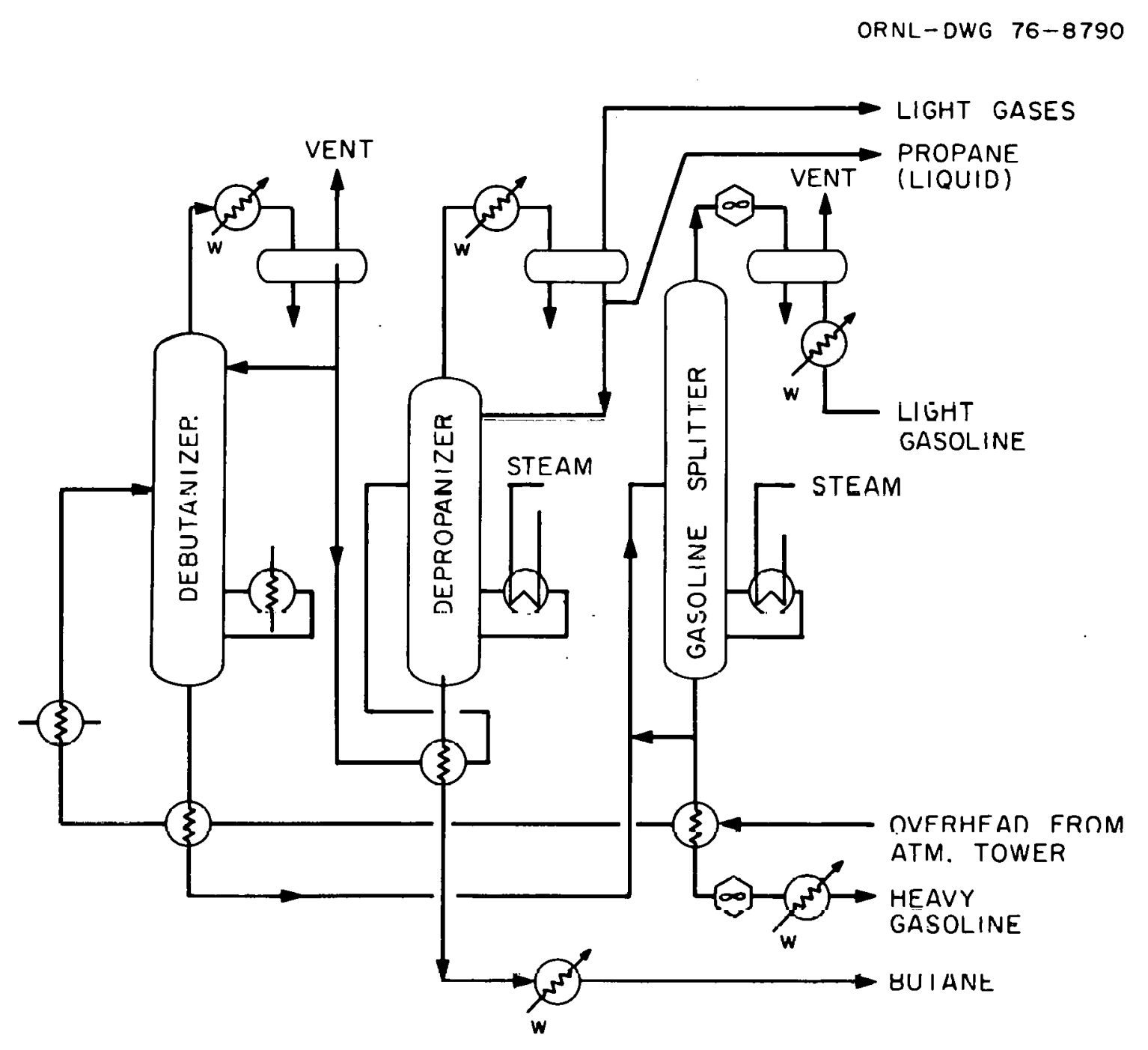

$\infty$ AIR COOLED

HEAT EXCHANGER

(3) Water cooled

HEAT EXCHANGER

(\$) PROCESS STREAM

Fig. B.4. Gas-separation system. 


\section{Cracking}

Cracking, the decomposition of large hydrocarbon molecules into smaller molecules, is identified as a thermal, catalytic, or hydrocracking process. Further separation of the processes and the extent of their capacity in U. S. refineries, based on the 1974 survey data of ref. 1, are given in Tables B.2.-B.4. Reforming, which involves hightemperature cracking of straight-run gasoline and naphtha, is discussed as a separate process.

Thermal processes, including coking, are used by $37 \%$ of U. S. refineries ( 60 to $75 \%$ of the large refineries but only $15 \%$ of the small refineries). Capacity for the thermal processes is $9 \%$ of the crude-oil capacity. Coking is by far the dominant thermal process (70\%) with delayed coking used seven times more than fluid coking. Most of the remainder of thermal-cracking capacity is equally divided between gasoil cracking and visbreaking. Visbreaking is a mild form of thermal cracking used to maximize furnace oil and minimize gasoline production. Gas-oil cracking using steam dilution is primarily used to produce light olefins. The survey data do not give the extent of steam cracking, and energy requirements were not determined for this report.

Catalytic cracking is performed at $57 \%$ of U. S. refineries (nearly all of the large refineries but only about $20 \%$ of the small refineries). Capacity of catalytic crackers is $29 \%$ of the crude-oil capacity. Fluid catalytic crackers account for $92 \%$ of the capacity with most of the remainder being the Thermofor process, accounting for about one-fourth of the catalytic-cracking capacity of small refineries. Only about $1 \%$ of catalytic cracking is by the Houdriflow process (four refineries). Most 
Table B.2. Relative U. S. refinery use of thermal processes

\begin{tabular}{|c|c|c|c|c|c|c|c|}
\hline \multirow{2}{*}{$\begin{array}{l}\text { Thermal } \\
\text { process }\end{array}$} & \multirow{2}{*}{$\begin{array}{c}\text { Percent of } \\
\text { thermal } \\
\text { processes }\end{array}$} & \multicolumn{6}{|c|}{$\begin{array}{l}\text { Percent for refinery size range } \\
\left(10^{3} \mathrm{bb} 1 / \mathrm{cd}\right) \text { of: }\end{array}$} \\
\hline & & $0-25$ & $25-50$ & $0-50$ & $50-100$ & $100-450$ & $0-450$ \\
\hline & & \multicolumn{6}{|c|}{ Percent of U. S. refineries. ${ }^{a}$} \\
\hline $\begin{array}{l}\text { Gas-oil cracking } \\
\text { Visbreaking } \\
\text { Fluid coking } \\
\text { Delayed coking } \\
\text { Other }\end{array}$ & $\begin{array}{r}13.4 \\
13.8 \\
8.7 \\
60.6 \\
3.5 \\
\end{array}$ & $\begin{array}{l}6.1 \\
2.6 \\
0.9 \\
2.6 \\
3.5 \\
\end{array}$ & $\begin{array}{r}6.5 \\
2.2 \\
4.3 \\
17.4 \\
4.3 \\
\end{array}$ & $\begin{array}{l}6.2 \\
2.5 \\
1.9 \\
6.8 \\
3.7 \\
\end{array}$ & $\begin{array}{r}11.9 \\
16.7 \\
2.4 \\
28.6 \\
0 \\
\end{array}$ & $\begin{array}{r}11.4 \\
13.6 \\
4.5 \\
52.3 \\
4.5 \\
\end{array}$ & $\begin{array}{r}8.1 \\
7.3 \\
2.4 \\
18.6 \\
3.2 \\
\end{array}$ \\
\hline \multirow[t]{2}{*}{ Total } & 100.0 & 15.7 & 34.7 & 21.1 & $3 / .1$ & 13.0 & 36.8 \\
\hline & & \multicolumn{6}{|c|}{ Percent of thermal-process capacity ${ }^{b}$} \\
\hline $\begin{array}{l}\text { Gas-oil cracking } \\
\text { Visbreaking } \\
\text { Fluid coking } \\
\text { Delayed coking } \\
\text { Other }\end{array}$ & & $\begin{array}{r}4.2 \\
5.3 \\
6.6 \\
1.3 \\
23.7\end{array}$ & $\begin{array}{r}4.5 \\
2.2 \\
9.5 \\
7.8 \\
14.5\end{array}$ & $\begin{array}{r}8.7 \\
7.5 \\
16.1 \\
9.1 \\
38.2\end{array}$ & $\begin{array}{l}18.2 \\
34.9 \\
16.8 \\
26 . ? \\
0\end{array}$ & $\begin{array}{l}73.1 \\
57.6 \\
67.1 \\
64.7 \\
61.8\end{array}$ & \\
\hline & & \multicolumn{6}{|c|}{ Percent of II.S. crude-oil capacity ${ }^{2}$} \\
\hline $\begin{array}{l}\text { Snf-nil cracking } \\
\text { Visbreaking } \\
\text { Fluid coking } \\
\text { Delayed coking } \\
\text { Other }\end{array}$ & & $\begin{array}{l}0.7 \\
0.9 \\
0.8 \\
1.1 \\
1.1 \\
\end{array}$ & $\begin{array}{l}0.5 \\
0.2 \\
0.7 \\
3.9 \\
u .4 \\
\end{array}$ & $\begin{array}{l}0.8 \\
0.4 \\
0.8 \\
2.8 \\
U .5 \\
\end{array}$ & $\begin{array}{l}1.1 \\
2.1 \\
0.6 \\
6.8 \\
0 \\
\end{array}$ & $\begin{array}{l}1.5 \\
1.2 \\
0.9 \\
6.1 \\
0.3 \\
\end{array}$ & $\begin{array}{l}1.3 \\
1.3 \\
0.8 \\
5.7 \\
0.3 \\
\end{array}$ \\
\hline Total & & 4.6 & 5.7 & 5.3 & 10.6 & 10.0 & 9.4 \\
\hline
\end{tabular}

a percent by size range - not percent of all refineries. Total is not necessarily additive because some refineries have more than one kind of process.

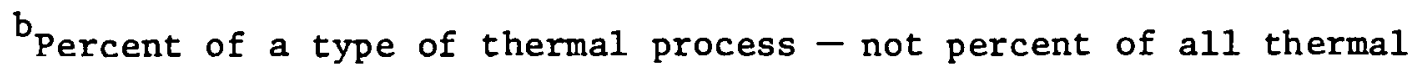
processes. 
Table B.3. Relative U.S. refinery use of catalytic-cracking processes

\begin{tabular}{|c|c|c|c|c|c|c|c|}
\hline \multirow{2}{*}{$\begin{array}{l}\text { Catalytic } \\
\text { cracking } \\
\text { process }\end{array}$} & \multirow{2}{*}{$\begin{array}{l}\text { Percent of } \\
\text { cat. cr. } \\
\text { processes }\end{array}$} & \multicolumn{6}{|c|}{$\begin{array}{c}\begin{array}{c}\text { Percent for refinery size range } \\
\left(10^{3} \mathrm{bbl} / \mathrm{cd}\right) \text { of: }\end{array}\end{array}$} \\
\hline & & $0-25$ & $25-50$ & $0-50$ & $50-100$ & $100-450$ & $0-450$ \\
\hline & & \multicolumn{6}{|c|}{ Percent of U.S. refineries ${ }^{a}$} \\
\hline $\begin{array}{l}\text { Fluid } \\
\text { Thermofor } \\
\text { Houdriflow }\end{array}$ & $\begin{array}{r}91.5 \\
6.9 \\
1.6 \\
\end{array}$ & $\begin{array}{r}13.9 \\
7.0 \\
0 \\
\end{array}$ & $\begin{array}{r}56.5 \\
19.6 \\
4.3 \\
\end{array}$ & $\begin{array}{r}26.1 \\
10.6 \\
1.2 \\
\end{array}$ & $\begin{array}{r}83.3 \\
9.5 \\
4.8 \\
\end{array}$ & $\begin{array}{r}95.5 \\
4.5 \\
0 \\
\end{array}$ & $\begin{array}{r}48.2 \\
9.3 \\
1.6 \\
\end{array}$ \\
\hline Total & 100.0 & 20.9 & 73.9 & 36.0 & 97.6 & 95.5 & 57.1 \\
\hline Recycle & 22.5 & 20.9 & 71.7 & 35.4 & 97.6 & 93.2 & 56.3 \\
\hline \multicolumn{8}{|c|}{ Percent of catalytic-cracking-process capacity ${ }^{b}$} \\
\hline $\begin{array}{l}\text { Fluid } \\
\text { Thermof or } \\
\text { Houdrif low }\end{array}$ & & $\begin{array}{c}2.3 \\
13.9 \\
0\end{array}$ & $\begin{array}{r}8.9 \\
36.5 \\
27.3\end{array}$ & $\begin{array}{l}11.2 \\
50.4 \\
27.3\end{array}$ & $\begin{array}{l}22.0 \\
32.3 \\
72.7\end{array}$ & $\begin{array}{c}66.8 \\
17.3 \\
0\end{array}$ & \\
\hline \multicolumn{8}{|c|}{ Percent of U.S. crude-oil capacity ${ }^{a}$} \\
\hline $\begin{array}{l}\text { Fluid } \\
\text { Thermofor } \\
\text { Houdriflow }\end{array}$ & & $\begin{array}{l}8.5 \\
3.9 \\
0 \\
\end{array}$ & $\begin{array}{r}20.8 \\
6.3 \\
1.1 \\
\end{array}$ & $\begin{array}{r}16.0 \\
5.4 \\
0.7 \\
\end{array}$ & $\begin{array}{r}26.9 \\
3.0 \\
1.5 \\
\end{array}$ & $\begin{array}{r}29.6 \\
0.5 \\
0 \\
\end{array}$ & $\begin{array}{r}26.5 \\
2.0 \\
0.4 \\
\end{array}$ \\
\hline Total & & 12.4 & 28.2 & 22.1 & 31.4 & 30.1 & 28.9 \\
\hline $\begin{array}{l}\mathrm{a}_{\text {Perce }} \\
\text { necessarily } \\
\text { process. }\end{array}$ & $\begin{array}{l}\text { size ra } \\
\text { Eive bec }\end{array}$ & $\begin{array}{l}\text { not } \\
\text { ome }\end{array}$ & $\begin{array}{l}\text { ent of } \\
\text { neries }\end{array}$ & ave & $\begin{array}{l}\text { inerie } \\
\text { ce tha }\end{array}$ & $\begin{array}{l}\text { Total } \\
\text { one kin }\end{array}$ & $\mathrm{f}^{\text {not }}$ \\
\hline
\end{tabular}


large refineries recycle about $22 \%$ of the catalytic-cracker feed (this percent is also the industry average), whereas the average recycle for small refineries is about $33 \%$ of the catalytic-cracker feed.

Hydrocracking is used primarily by large refineries $-57 \%$ of large U. S. refineries and $16 \%$ of all U. S. refineries. Hydrocracking capacity is $5 \%$ of crude-oil capacity. The main use is for upgrading distillate; other small uses are for upgrading residual and for lube-oil manufacturing.

Thermal cracking and visbreaking

Thermal cracking and visbreaking processes differ mainly in severity (i.e., time, temperature, and pressure). There are many variations of these processes depending on the characteristics of the feed and the desired products. Thus equipment classified as thermal cracking might be used for visbreaking and vice versa. Figures B.5. and B.6. show examples of thermal-cracking and visbreaking processes respectively. for the fllustrated thermal-cracking process, topped crude oil (bottom stream from a distillation unit) is heated by direct heat exchange with the cracked products in a fractionating column. Light and heavy oil from the fractionating column are pumped through a furnace as separate streams. The lighter oil is heated to a higher temperature and pressure than the heavier oil, about $521^{\circ} \mathrm{C}$ and 500 to $700 \mathrm{psig}$ and $504^{\circ} \mathrm{C}$ and 300 to 500 psig $\left(970\right.$ and $940^{\circ} \mathrm{F}$ ) respectively. ${ }^{17}$ Light oil is not recycled when heating oil is the desired product; otherwise recycle is about 2.5 and 3.5 times the throughput for the light and heavy oil respectively. 10 The two streams from the furnace are combined and transferred through a reaction chamber to a flash chamber from which the heavy portion is 
ORNL-DWG 76-8789

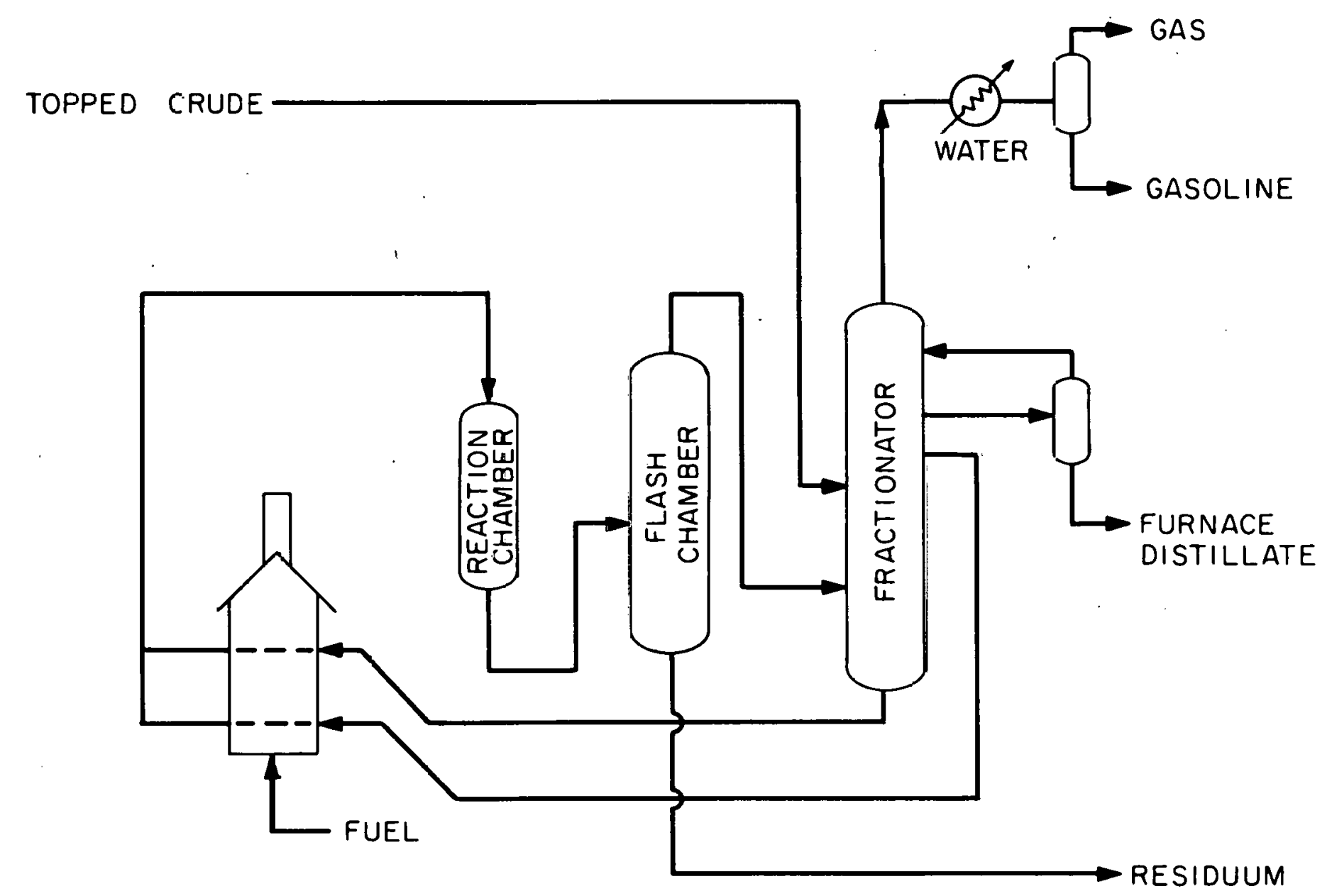

Fig. B.5. Thermal-cracker ş̦stem. 
ORNL-DWG 76-8788

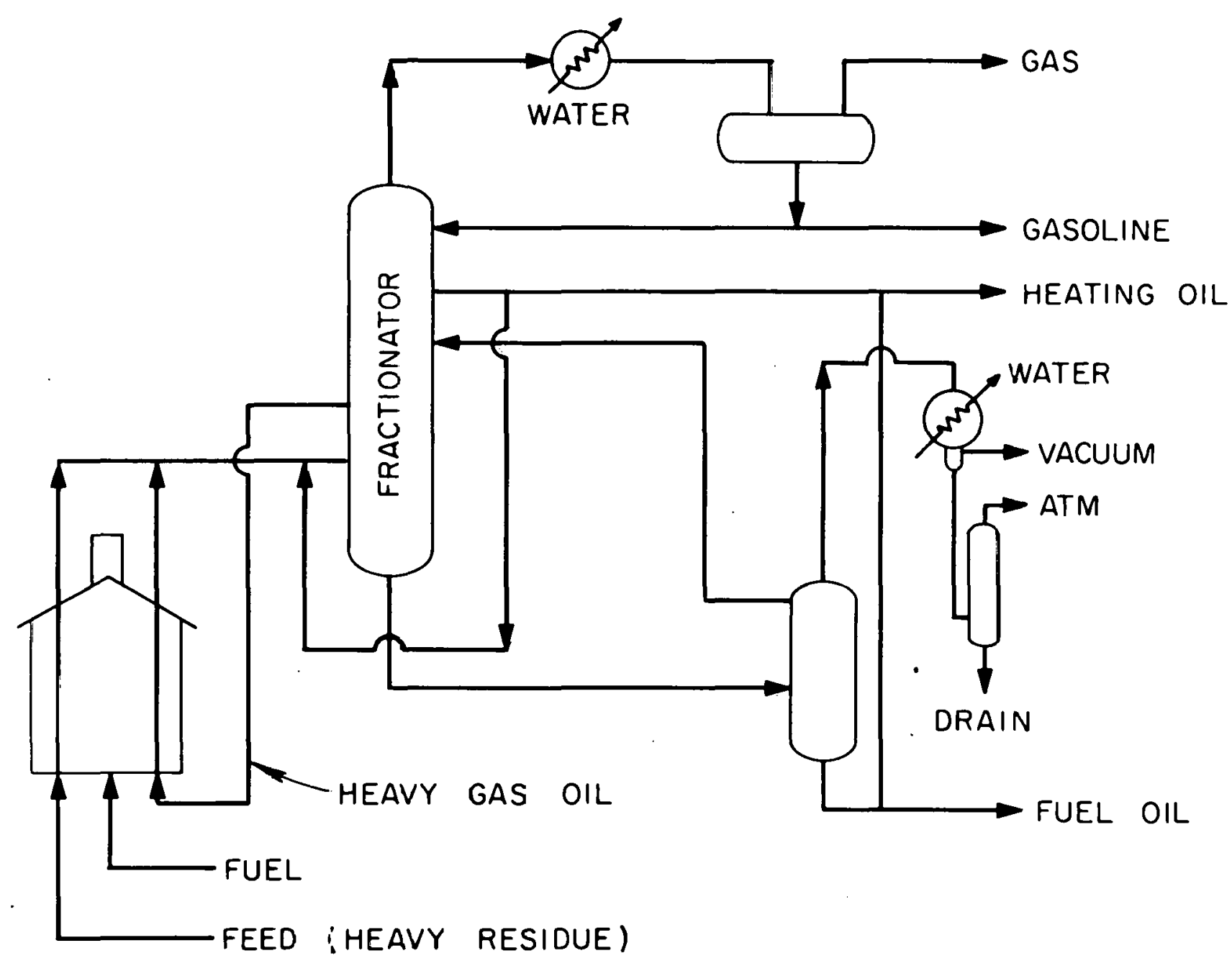

Fig. B.6. Visbreaker system. 
removed from the bottom and the rest is returned to the fractionator. Furnace distillate is drawn from the side of the fractionator. Gas and gasoline from the top of the fractionator are cooled and separated. Visbreaking is a mild form of thermal cracking sometimes used to reduce the viscosity of heavy residues with little reduction of the boiling point, resulting less light heating oil being required to blend the residue to an acceptable fuel oil. For the visbreaking process illustrated in Fig. B.6., feed is heated to about $482^{\circ} \mathrm{C}\left(900^{\circ} \mathrm{F}\right)$ and mixed with a recycle stream of heated heavy gas $011 .{ }^{13}$ Pressure is in the range of 50 to $300 \mathrm{psig}$. The furnace is designed to provide a "soaking" section to allow time for the reactions to be compleced. Afrer quenching by a recycle stream of product heating oil, the gas, gasoline, heating oil, and residuum are separated in a fractionating section. The residuum is then passed through a vacuum tower with the overhead being returned to the fractionator and the bottoms becoming a fuel oil. Coking

Coking is a form of thermal cracking in which heavy residues are converted into gas, naphtha, heating oil, and coke. Coking is a more severe process than ordinary thermal cracking in that the heavy oil is maintained at a high temperature tor a longer peritod of time. Of the major coking processes, delayed coking is used much more than fluid coking.

The delayed-coking process is similar to the process described previously for thermal cracking except that only heavy oil is fed to the furnace and soaking drums are provided to prolong the reaction time. Coke which accumulates in the soaking drums must be removed every one or two 
days; thus multiple soaking drums are provided to allow continuous operation. Coke is removed from the drums by drilling a hole in the deposit and using high-pressure water jets as cutting devices. Furnace outlet temperature is about $499^{\circ} \mathrm{C}\left(930^{\circ} \mathrm{F}\right)$; coke drum pressure and temperature are 10 to $70 \mathrm{psig}$ and about $432^{\circ} \mathrm{C}\left(810^{\circ} \mathrm{F}\right)$. Figure B.7.a. is a schematic dlagram of a delayed-coking system.

Fluid coking, shown schematically in Fig. B.7.b., is a continuous process with coke being deposited on coke fines coming from a heater chamber which receives coke from the reactor vessel. Air is supplied to the heater chamber where some of the coke is burned to supply some of the process heat requirements and to generate some steam. Heavy residue is fed to the reactor vessel in which there is a fluidized bed of coke particles. The top of the reactor vessel has a scrubber-fractionator to separate the particulate material and hydrocarbon fractions from the heavier oils being recycled. Because some of the coke is burned, the fluid-coking process has less coke product than the delayed-coking process. Operating temperatures and pressures are 480 to $565^{\circ} \mathrm{C}$ (900 to $\left.1050^{\circ} \mathrm{F}\right)$ and 0 to 15 psig.

A variation of the fluid-coking process is shown schematically by Fig. B.7.C. The process is similar to the fluid-coking process described previously, but the coke is transferred between the heater and a gasifier in which all the net coke produced is gasified by steam and air. After furnishing process heat and generating steam, the gases are cooled, scrubbed, and desulfurized to a low-sulfur fuel gas. Catalytic cracking

Catalytic cracking using the fluid-bed-type unit, FCCU, is the dominant form of cracking process. Less used are catalytic cracking 


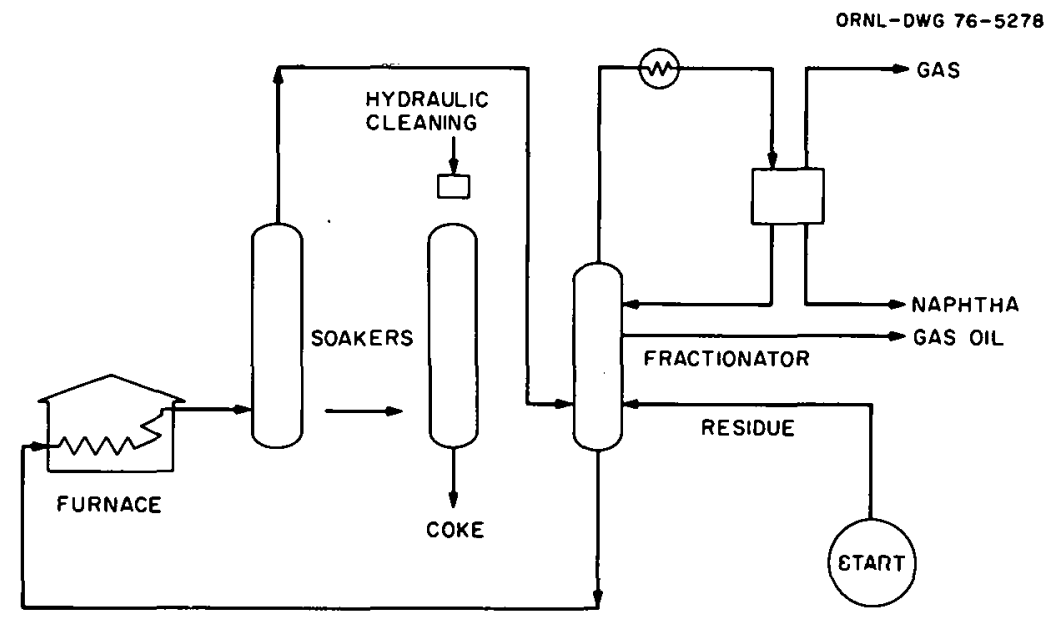

(a) DELAYED COKING PROCESS

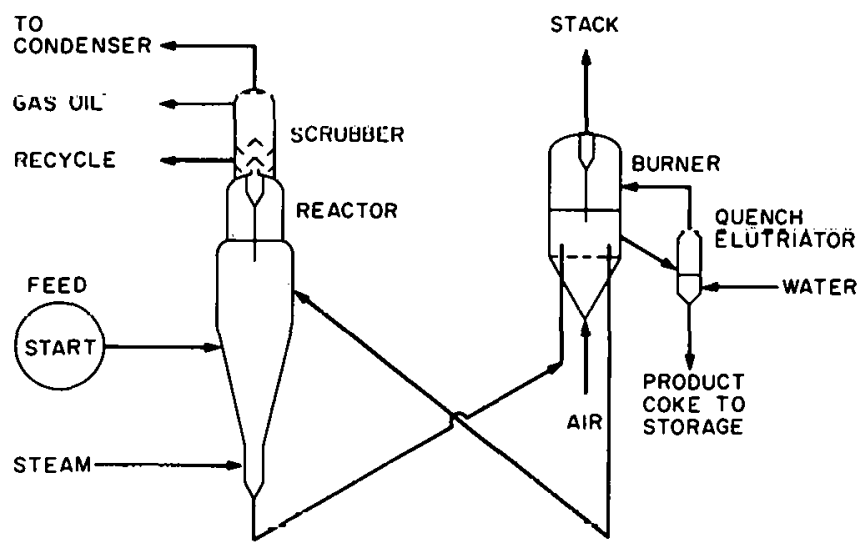

(b) FLUID COKING PROCESS

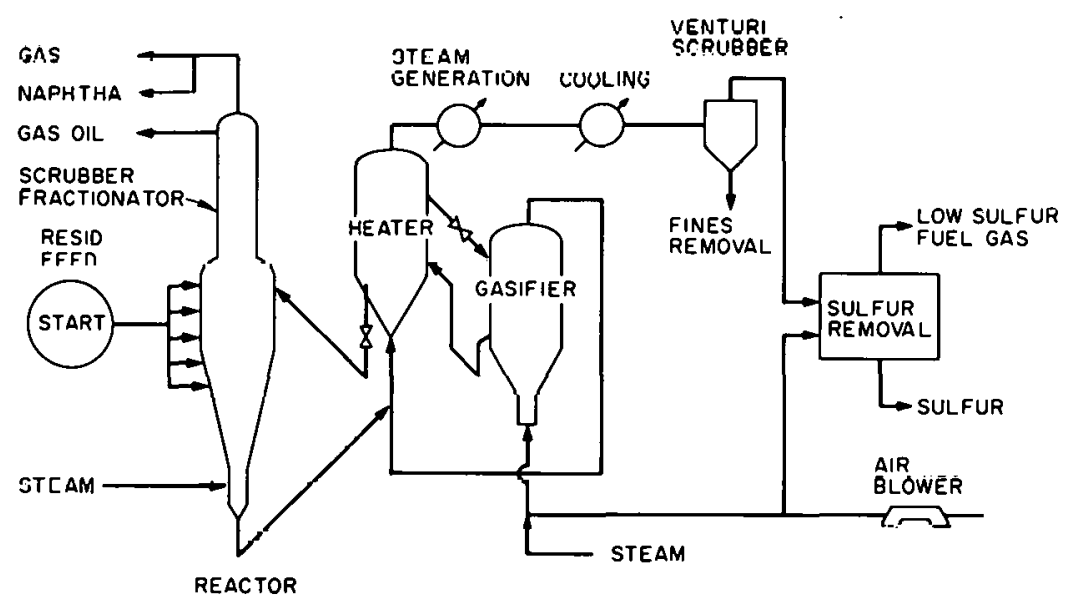

(c) FLUIO COKING PROCESS WITH GASIFICATION

Fig. B.7. Coking processes.

Sources (a), (b): G. D. Hobson, Modern Petroleum Technology, 4th ed., John Wiley and Sons, New York, 1973, p. 283; p. 285.

(c): D. E. Blaser, J. A. Rionda, and A. L. Saxton, Combine Desulfurizing and Coking, Hydrocarbon Processing, vol. 50 (9), Gulf Publishing Company, Houston, Tex., September 1971, p. 140. 
units of the moving-bed type in which the catalyst moves by gravity through the reactor and regenerator vessels and is returned to the top of the unit by a gas lift. Most of the gas-lift units are Thermofor air-lift units; only four refineries have the Houdriflow type.

There are several versions of FCC units. The main obvious difference is in the height of the units caused by the relative placement of the reactor and regenerator sections. Functionally the fluid-bed catalytic units have evolved from those with a reactor vessel for the cracking region to those in which most of the cracking occurs in a riser leg which receives feed and regenerated catalyst at its lower end and delivers the cracked feed and coked-catalyst to a disengager tank. Insufficient information is available in the literature to reach conclusions about their relative energy consumption. However, it seems likely that for a given degree of processing and effectiveness of the catalyst, the smaller units and those in which most of the cracking occurs in the dilute phase during catalyst transfer would be more energy-efficient.

In any case, coke formed during cracking deposits on the catalyst and must be burned off to regenerate the catalyst. In FCCU removal is thus accomplished with low-excess oxygen at temperatures of 565 to $704^{\circ} \mathrm{C}$ (1050 to $1300^{\circ} \mathrm{F}$ ) and pressures of 15 to $35 \mathrm{psig}$. The resultant gas is a mixture of $\mathrm{CO}$ and $\mathrm{CO}_{2}$ at sufficiently high temperature and pressure to provide a substantial supply of energy which can be recovered by use of heat exchangers, turbocxpandero, and CO boilers.

Figures B.8. and B.9. show schematic diagrams of moving-bed and fluidized-catalytic-cracking units respectively. 


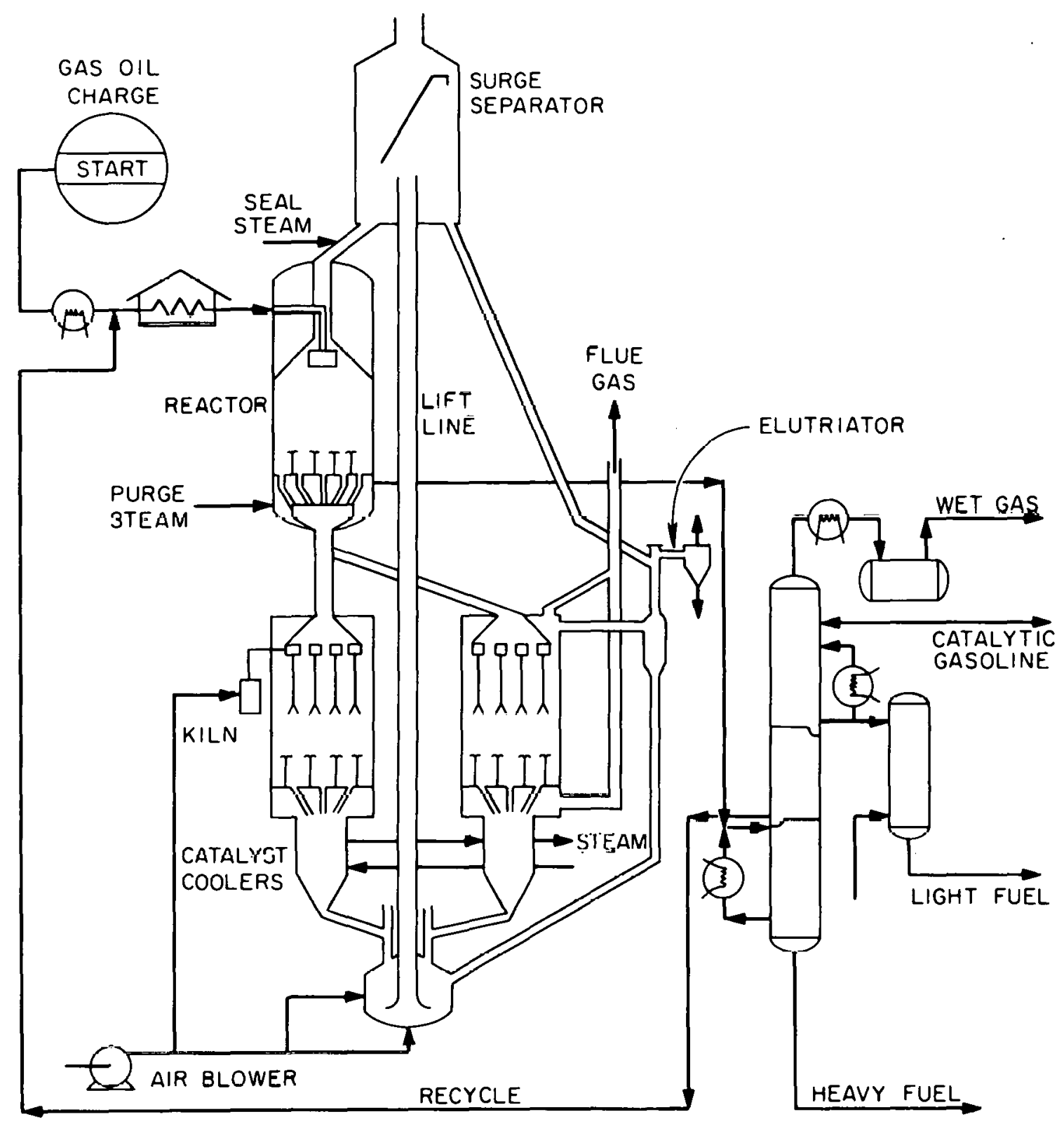

Fig. B.8. Thermofor moving-bed catalytic unit.

Source: G. D. Hobson, Modern Petroleum Technology, 4th ed., John Wiley and Sons, New York, 1973, p. 293. 


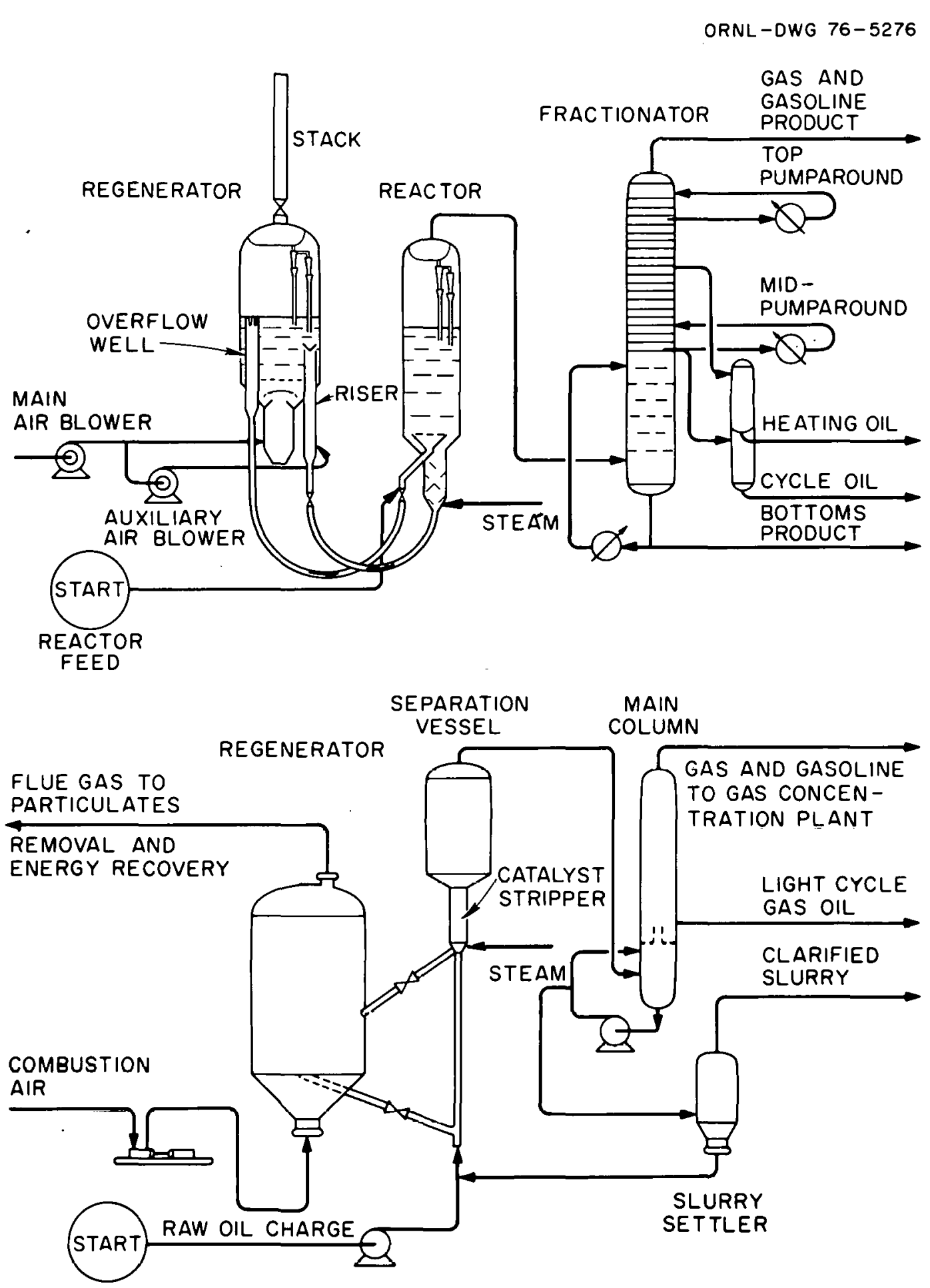

Fig. B.9. Fluid-bed catalytic cracker units.

Sources: 1974 Refining Process Handbook, Hydrocarbon Processing, vol. 53 (9), Gulf Publishing Company, Houston, Tex., September 1974, p. 118.

1966 Refining Process Handbook, Hydrocarbon Processing, vol. 45 (9), Gulf Publishing Company, Houston, Tex., September 1966 , p. 188. 


\section{Hydrocracking}

Hydrocracking is a pressurized-hydrogen catalytic process used to convert refractory middle-boiling or residual material to high-octane gasoline, reformer feed, and high-grade fuels by cracking, hydrogenation, isomerization, and hydrotreating reactions. Upgrading of distillate is the predominate use made of hydrocracking. Most hydrocracker designs are of the fixed-bed type; however, at least one design involves a moving-catalyst bed operated such that upflow of fluid keeps the catalyst in an "abbullating" state. The temperature for hydrocracking is 340 to $420^{\circ} \mathrm{C}\left(644\right.$ to $\left.790^{\circ} \mathrm{F}\right)$ and pressure is 1200 to $2000 \mathrm{psig}$. Hydrogen consumption is about 1500 to 2000 sct/bbl of feed and hydiegen recycle is about 8000 to $15,000 \mathrm{scf} / \mathrm{bbl}$ of feed. However, consumption is much less than this total if the unit is used solely as a desulfurizer and much higher ( $3000 \mathrm{scf} / \mathrm{bbl})$ if used for gasoline production from high-boiling material.

Hydrogen from reforming can be used for the hydrocracking; however, assuming hydrotreating and/or hydrorefining are practiced, this supply is sufficient only if a limited amount of hydrocracking is performed. Usually a supplemental hydrogen supply is required. Because hydrogen has value, especially when also used to produce low-sulfur fuels, and requires energy for its production, it seems appropriate to assign an energy requirement to the hydrocracking process for the hydrogen used. For this study the energy required to produce the hydrogen is assumed to be as follows: 


\begin{tabular}{lc}
\hline & $\frac{\text { Energy requirement }}{\left(\text { Btu } / 10^{3} \text { scf } \mathrm{H}_{2}\right)}$ \\
\hline Electricity & 11,000 \\
Fue1 & 222,000 \\
Steam & break even \\
\multicolumn{1}{c}{ TOTAL } & 233,000 \\
\hline
\end{tabular}

Figure B.10. shows schematic diagrams of fixed-bed and movingcatalyst-bed systems.

\section{Catalytic Reforming}

Catalytic reforming of low-octane naphtha to a high-octane material and to aromatics for petroleum feedstocks is preferred to thermal reforming because of better control of the reactions and better product yields. These factors also make the present (catalytic) reformers the more energy efficient type. There are about 15 variations of catalytic reformers of two basic types - cyclic or semiregenerative - each of which uses either a conventional (usually platinum-on-alumina) catalyst or bimetallic (rhenium or tin in addition to platinum). The extent and distribution of catalytic reforming by these types of units, based on the 1974 survey data of ref. 1, are given in Table B.5. Catalytic reforming is used by $70 \%$ of U. S. refineries (nearly all of the large refineries but only half of the small refineries). Catalytic-reformer capacity is $21 \%$ of crude-oil capacity (22\% for large refineries and $10 \%$ for small refineries). Use of the semiregenerative type predominates with about equal use of conventional and bimetallic catalyst. Most of the remaining reforming is by the cyclic process using conventional catalysts. 

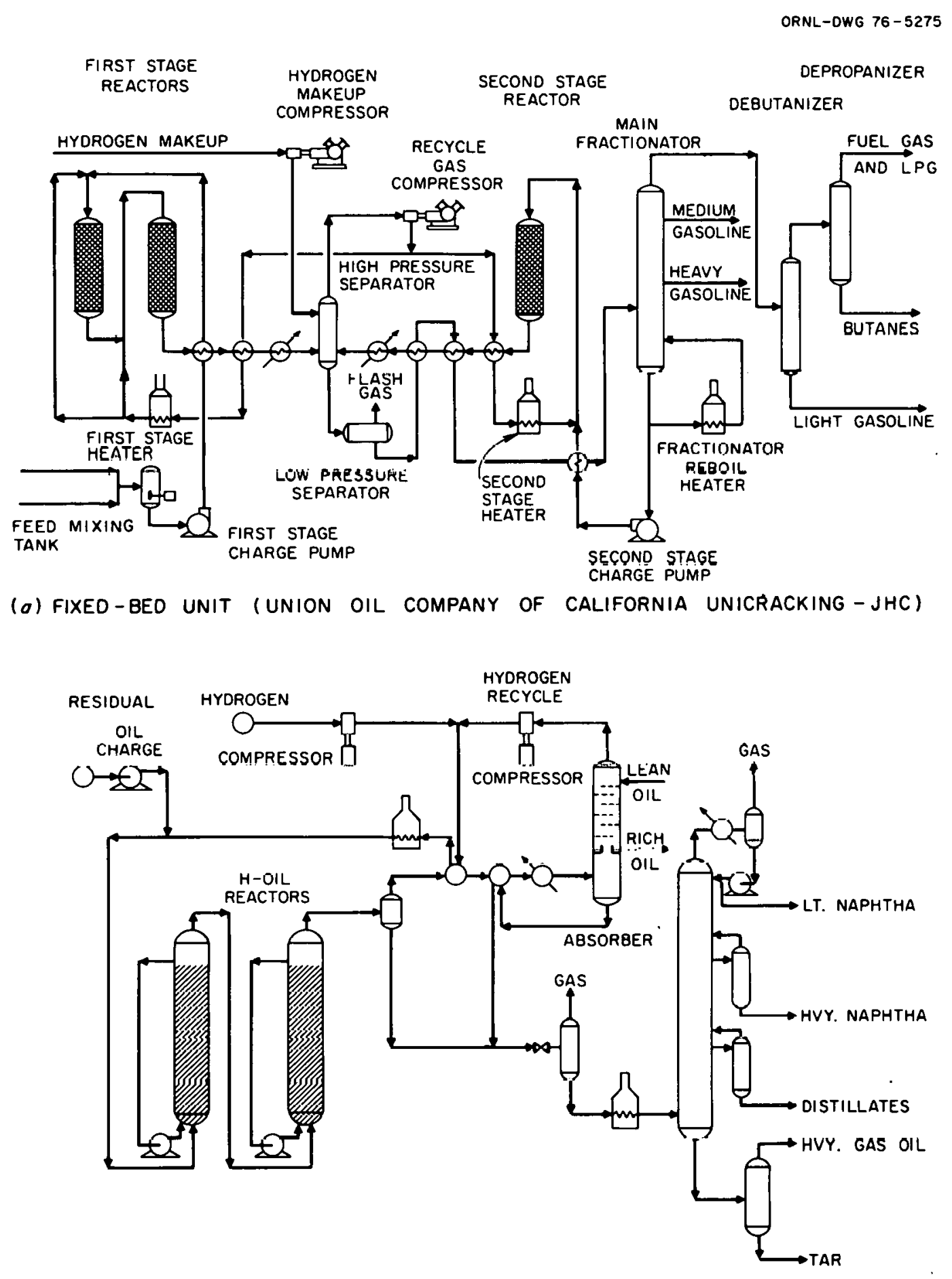

(b) MOVING - CATALYST UNIT (H-OIL)

Fig. B.10. Hydrocracker units.

Source: G. D. Hobson, Moderm Petroleum Technology, 4 th ed., John Wiley and Sons, New York, 1973, p. 313, 320. 
Table B.5. Relative U.S. refinery use of catalytic-reforming processes

\begin{tabular}{|c|c|c|c|c|c|c|c|}
\hline \multirow{2}{*}{$\begin{array}{l}\text { Catalytic } \\
\text { reforming } \\
\text { process }\end{array}$} & \multirow{2}{*}{$\begin{array}{l}\text { Percent of } \\
\text { cat. ref. } \\
\text { processes }\end{array}$} & \multicolumn{6}{|c|}{$\begin{array}{l}\text { Percent for refinery size range } \\
\left(10^{3} \mathrm{bbl} / \mathrm{cd}\right) \text { of: }\end{array}$} \\
\hline & & $0-25$ & $25-50$ & $0-50$ & $50-100$ & $100-450$ & $0-450$ \\
\hline & & \multicolumn{6}{|c|}{ Percent of U.S. refineries ${ }^{a}$} \\
\hline $\begin{array}{l}\text { Semiregenerative } \\
\text { Conventional } \\
\text { Bimetallic }\end{array}$ & $\begin{array}{l}70.0 \\
35.0 \\
35.0\end{array}$ & $\begin{array}{l}36.5 \\
23.5 \\
13.0\end{array}$ & $\begin{array}{l}73.9 \\
32.6 \\
41.3\end{array}$ & $\begin{array}{l}47.2 \\
26.1 \\
21.1\end{array}$ & $\begin{array}{l}85.7 \\
45.2 \\
40.5\end{array}$ & $\begin{array}{l}86.4 \\
45.5 \\
40.9\end{array}$ & $\begin{array}{l}60.7 \\
32.8 \\
27.9\end{array}$ \\
\hline $\begin{array}{l}\text { Cyclic } \\
\quad \text { Conventional } \\
\text { Bimetallic }\end{array}$ & $\begin{array}{r}27.2 \\
25.0 \\
2.2\end{array}$ & $\begin{array}{l}5.2 \\
2.6 \\
2.6\end{array}$ & $\begin{array}{l}8.7 \\
8.7 \\
0\end{array}$ & $\begin{array}{l}6.2 \\
4.3 \\
1.9\end{array}$ & $\begin{array}{r}14.3 \\
11.9 \\
2.4\end{array}$ & $\begin{array}{r}36.4 \\
34.1 \\
2.3\end{array}$ & $\begin{array}{r}12.9 \\
10.9 \\
2.0\end{array}$ \\
\hline Other & 2.8 & 0 & 2.2 & 0.6 & 9.5 & 2.3 & 2.4 \\
\hline Total & 100.0 & 41.7 & 84.8 & 54.0 & 100.0 & 100.0 & 70.0 \\
\hline \multicolumn{8}{|c|}{ Percent of catalytic-reforming-process capacity ${ }^{c}$} \\
\hline $\begin{array}{l}\text { Semiregenerative } \\
\text { Conventional } \\
\text { Bimetallic }\end{array}$ & & $\begin{array}{l}4.6 \\
5.5 \\
3.6\end{array}$ & $\begin{array}{l}12.4 \\
11.1 \\
13.8\end{array}$ & $\begin{array}{l}17.0 \\
16.6 \\
17.4\end{array}$ & $\begin{array}{l}26.5 \\
26.2 \\
26.8\end{array}$ & $\begin{array}{l}56.5 \\
57.2 \\
55.8\end{array}$ & \\
\hline $\begin{array}{l}\text { Cyclic } \\
\text { Conventional } \\
\text { Bimetallic }\end{array}$ & & $\begin{array}{l}1.2 \\
0.4 \\
9.6\end{array}$ & $\begin{array}{l}4 \cdot 1 \\
4.4 \\
0\end{array}$ & $\begin{array}{l}5.2 \\
4.8 \\
9.6\end{array}$ & $\begin{array}{r}8.8 \\
8.4 \\
13.7\end{array}$ & $\begin{array}{l}86.0 \\
86.8 \\
76.7\end{array}$ & \\
\hline Other & & 0 & 6.4 & 6.4 & 72.3 & 21.3 & \\
\hline \multicolumn{8}{|c|}{ Percent of U.S. crude-oil capacity ${ }^{a}$} \\
\hline $\begin{array}{l}\text { Semiregenerative } \\
\text { Conventional } \\
\text { Bimetallic }\end{array}$ & & $\begin{array}{l}9.4 \\
5.7 \\
3.7\end{array}$ & $\begin{array}{r}16.1 \\
7.2 \\
8.9\end{array}$ & $\begin{array}{r}13.5 \\
6.6 \\
6.9\end{array}$ & $\begin{array}{r}18.1 \\
8.9 \\
9.2\end{array}$ & $\begin{array}{r}14.0 \\
7.1 \\
6.9\end{array}$ & $\begin{array}{r}14.9 \\
7.5 \\
7.4\end{array}$ \\
\hline $\begin{array}{l}\text { Cycllc } \\
\text { Conventional } \\
\text { Bimetallic }\end{array}$ & & $\begin{array}{l}0.9 \\
0.3 \\
0.6\end{array}$ & $\begin{array}{l}2.1 \\
2.1 \\
0\end{array}$ & $\begin{array}{l}1.6 \\
1.4 \\
0.2\end{array}$ & $\begin{array}{l}2.3 \\
2.0 \\
0.3\end{array}$ & $\begin{array}{l}8.3 \\
7.7 \\
0.6\end{array}$ & $\begin{array}{l}5.7 \\
5.3 \\
0.4\end{array}$ \\
\hline Other ${ }^{b}$ & & 0 & 0.4 & 0.2 & 2.0 & 0.2 & 0.6 \\
\hline Total & & 10.3 & 18.6 & 15.3 & 22.4 & 22.5 & 21.2 \\
\hline \multicolumn{8}{|c|}{$\begin{array}{l}\text { a Percent by size range - not percent of all refineries. Total is not } \\
\text { necessarily additive because some refineries have more than one kind of } \\
\text { process. }\end{array}$} \\
\hline
\end{tabular}


The cyclic units ordinarily operate at lower pressure and higher temperature at the expense of more rapid deactivation of the catalyst by coke deposition because a "swing" reactor provides for reactivation of the catalyst on a regular three-to-five-day schedule. The advantage of this cyclic process is that the yields of aromatics and hydrogen are increased and the hydrogen-to-oil mole ratio may be lower.

For either process type, feed and the hydrogen which is recycled from the process are heated in furnaces and sometimes by heat exchange; ocnt to a ocrioe of threo or four reactors; and further heated in furnaces between each reactor. The cyclic process always provides for by-passing one of the reactors so that the reactors may be rotated through catalyst-regeneration cycles. By proper choice of operating parameters the semiregenerative process is able to extend to several months the time between catalyst regenerations. Bimetallic catalyst also allow oepration at lower pressures, lower temperatures, and longer times. Approximate operating characteristics for catalytic reforming are as follows:

\begin{tabular}{lcc}
\hline & Cyclic & Semiregenerative $^{a}$ \\
\hline Pressure (psig) & $200-350$ & $300-600$ \\
Temperature $\left({ }^{\circ} \mathrm{C} /{ }^{\circ} \mathrm{F}\right)$ & $500-540 / 932-1004$ & $450-540 / 842-1004$ \\
Hydrogen/oil mole ratio & $3: 1-5: 1$ & $5: 1-10: 1$ \\
Hydrogen production (scf/bb1) & $1000-1500$ & $700-1500$ \\
\hline
\end{tabular}

asource: G. D. Hobson, Moderm Petroleum Technology, 4th ed., John Wiley and Sons, New York, 1973, p. 338, 340.

Figure B.11 shows schematic diagrams of cyclic- and semiregenerativetype catalytic reformers. 


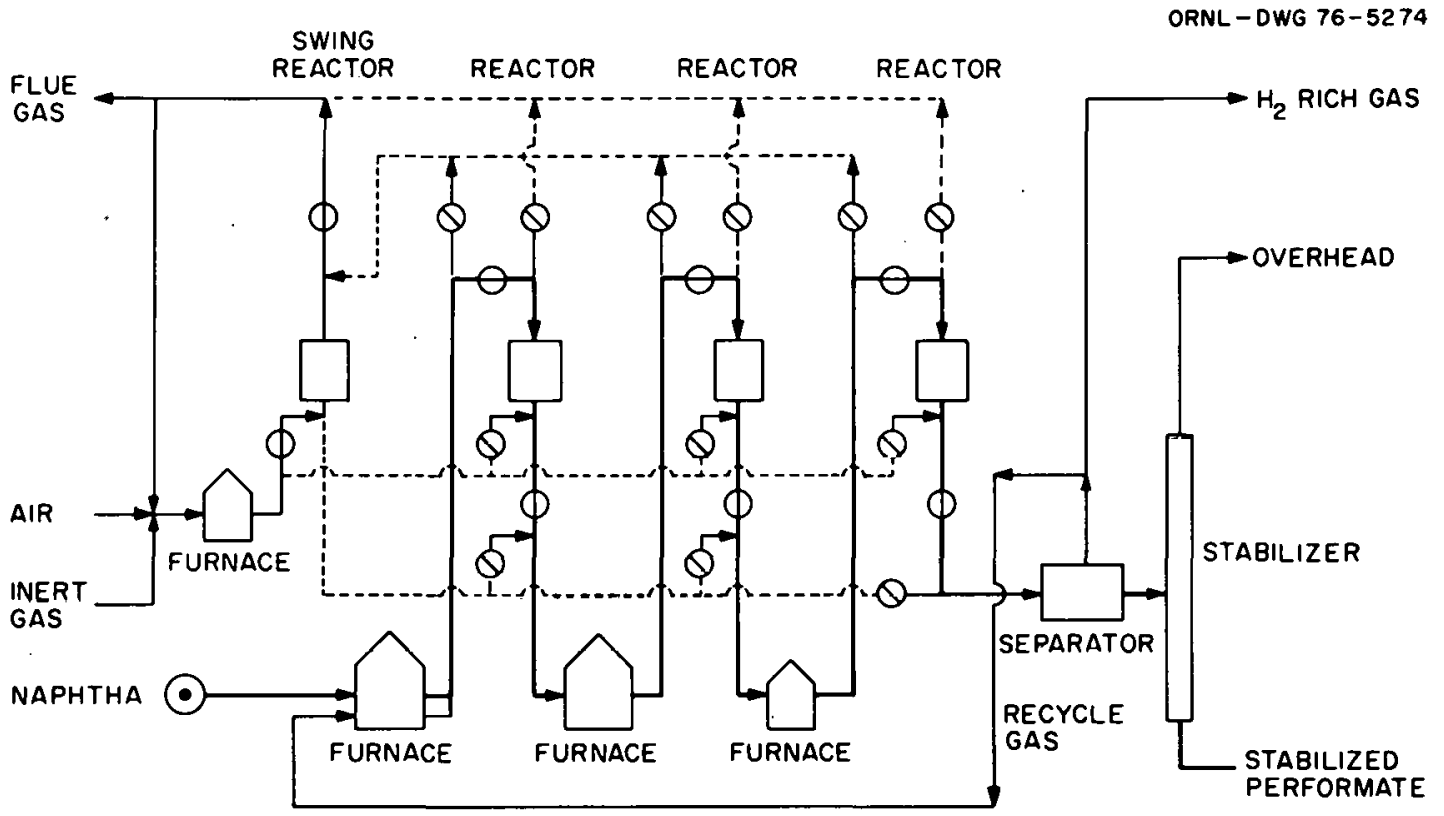

(a) CYCLIC

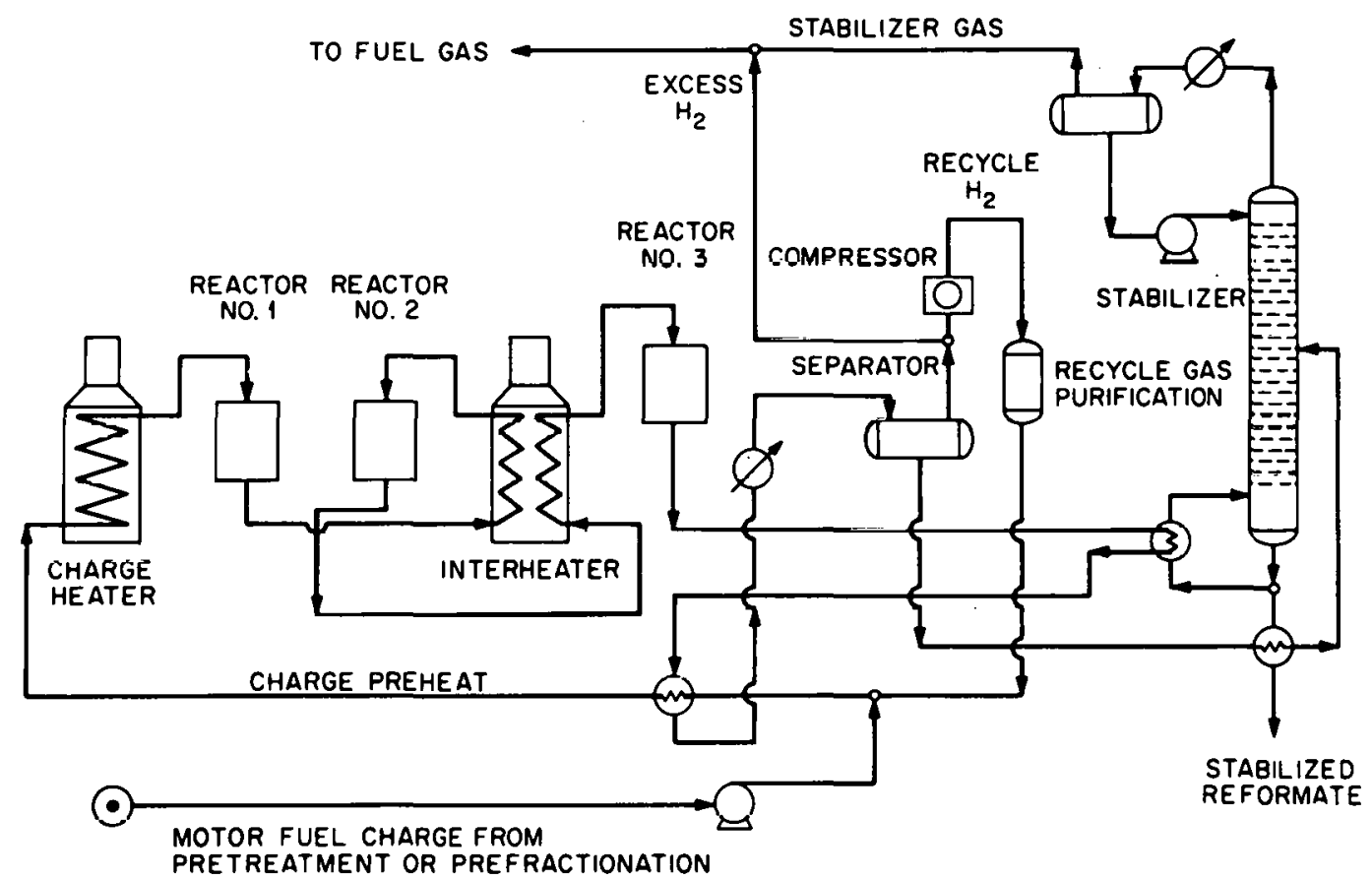

(b) SEMIREGENERATIVE

Fig. B.11. Catalyt1c reformer units.

Source: G. D. Hobson, Moderm Petrolevon Technology, 4th ed., John Wiley and Sons, New York, 1973, p. 338, 342. 


\section{Catalytic Hydrorefining}

Catalytic hydrorefining as discussed here follows the ref. 1 description of applications, identified along with the extent of U.S. capacity in Table B.6. Catalytic hydrorefining is used by $19 \%$ of U. S. refineries (predominately by large refineries). Capacity is $6 \%$ of the crude-oil capacity. Primary uses are to treat middle distillates and catalytic-cracker and stock feeds. Lesser uses are desulfurization of residual and gas oil.

Many variations of units to preform catalytic hydrorefining exist, all of which basically are very similar. Hydrogen and feed are heated and passed over a fixed-bed catalyst. The materials are then cooled and separated into several components; gases, after $\mathrm{H}_{2} \mathrm{~S}$ removal, are recycled and the liquids are further separated into the desired products. The catalyst commonly is cobalt molybdate on an alumina support. Regeneration of the catalyst is required only infrequently. Temperature and pressure are in the range of 315 to $455^{\circ} \mathrm{C}$ (599 to $851^{\circ} \mathrm{F}$ ) and 200 to 1000 psig. However, extremes of these values are avoided because at low pressure and high temperature there is excessive carbon deposition on the catalyst, increasing the frequency of regenerac1on, and high pressure and low temperature favor undesired reactions such as aromatics converting to naphthenes: Gas is recycled at a rate of 300 to 5000 $\mathrm{scf} / \mathrm{bb} 1$ and makeup hydrogen at 400 to $1000 \mathrm{scf} / \mathrm{bbl}$.

F1gure B.12. is a schematic diagram of a catalytic-hydrorefining unit.

\section{Catalytic Hydrotreating}

Catalytic hydrotreating as discussed here follows the ref. 1 description of applications, identified along with the extent of U.S. 
Table B.6. Relative U.S. refinery use of catalytic hydrorefining

\begin{tabular}{|c|c|c|c|c|c|c|c|}
\hline \multirow{2}{*}{$\begin{array}{l}\text { Process } \\
\text { used to: }\end{array}$} & \multirow{2}{*}{$\begin{array}{l}\text { Percent } \\
\text { of cat. } \\
\text { hydroref. }\end{array}$} & \multicolumn{6}{|c|}{$\begin{array}{l}\text { Percent for refinery size range } \\
\left(10^{3} \mathrm{bbl} / \mathrm{cd}\right) \text { of: }\end{array}$} \\
\hline & & $\overline{0-25}$ & $25-50$ & $0-50$ & $50-100$ & $100-450$ & $0-450$ \\
\hline \multirow{6}{*}{$\begin{array}{l}\text { Desulf. residual } \\
\text { Desulf. gas-oil } \\
\text { Pretreat cat. cr. } \\
\text { and stock feed } \\
\text { Treat mid. dist. } \\
\text { Other }\end{array}$} & \multirow{3}{*}{$\begin{array}{r}1.0 \\
15.7\end{array}$} & \multicolumn{6}{|c|}{ Percent of U.S. refineries ${ }^{a}$} \\
\hline & & \multirow{2}{*}{$\begin{array}{l}0.9 \\
0\end{array}$} & \multirow{2}{*}{$\begin{array}{l}0 \\
2.2\end{array}$} & \multirow{2}{*}{$\begin{array}{l}0.6 \\
0.6\end{array}$} & \multirow{2}{*}{$\begin{array}{l}0 \\
2.4\end{array}$} & \multirow{2}{*}{$\begin{array}{l}2.3 \\
6.8\end{array}$} & \multirow{2}{*}{$\begin{array}{l}0.8 \\
2.0\end{array}$} \\
\hline & & & & & & & \\
\hline & & & & & & & \\
\hline & 33.2 & 0.9 & 6.5 & 2.5 & 16.7 & 13.6 & 6.9 \\
\hline & $\begin{array}{r}48.5 \\
1.6\end{array}$ & $\begin{array}{l}0.9 \\
1.7\end{array}$ & $\begin{array}{c}19.6 \\
0\end{array}$ & $\begin{array}{l}6.2 \\
1.2\end{array}$ & $\begin{array}{c}16.7 \\
0\end{array}$ & $\begin{array}{r}20.5 \\
4.5 \\
\end{array}$ & $\begin{array}{r}10.5 \\
1.6 \\
\end{array}$ \\
\hline \multirow[t]{2}{*}{ Total } & 100.0 & 4.3 & 21.7 & 9.3 & 35.7 & 40.9 & 19.4 \\
\hline & \multicolumn{7}{|c|}{ Percent of process-capacity use $e^{b}$} \\
\hline \multirow{5}{*}{$\begin{array}{l}\text { Desulf. residual } \\
\text { Desulf. gas-oil } \\
\text { Pretreat cat. cr. } \\
\text { and stock feed } \\
\text { Treat mid. dist. } \\
\text { Other }\end{array}$} & & 42.9 & 0 & $\begin{array}{r}42.9 \\
5.0\end{array}$ & $\begin{array}{l}0 \\
138\end{array}$ & 57.1 & \\
\hline & & & & & & & \\
\hline & & 1.2 & 6.7 & 7.9 & 32.0 & 60.1 & \\
\hline & & $\begin{array}{r}0.2 \\
36.0\end{array}$ & $\begin{array}{c}10.0 \\
0\end{array}$ & $\begin{array}{l}10.2 \\
36.0\end{array}$ & $\begin{array}{c}20.4 \\
0\end{array}$ & $\begin{array}{l}69.4 \\
64.0\end{array}$ & \\
\hline & & \multicolumn{6}{|c|}{ Percent of U.S. crude-oil capacity ${ }^{a}$} \\
\hline \multirow{5}{*}{$\begin{array}{l}\text { Desulf. residual } \\
\text { Desulf. gas-oil } \\
\text { Pretreat cat. cr. } \\
\text { and stock feed } \\
\text { Treat mid. dist. } \\
\text { Other }\end{array}$} & & $\begin{array}{l}0.4 \\
0\end{array}$ & $\begin{array}{l}0 \\
0.4\end{array}$ & $\begin{array}{l}0.2 \\
0.3\end{array}$ & $\begin{array}{l}0 \\
1.2\end{array}$ & $\begin{array}{l}\text { c } \\
1.4\end{array}$ & $\begin{array}{l}c \\
1.0\end{array}$ \\
\hline & & & & & & & \\
\hline & & 0.4 & 1.3 & 0.9 & 6.0 & 2.2 & 2.1 \\
\hline & & 0.1 & 2.7 & 1.7 & 5.6 & 3.6 & 3.1 \\
\hline & & 0.5 & 0 & 0.2 & 0 & 0.1 & $c$ \\
\hline Total & & 1.4 & 4.4 & 3.3 & 12.8 & 7.3 & 6.2 \\
\hline
\end{tabular}

${ }^{a}$ Percent by size range - not percent of all refineries. Total is not necessarily additive because some refineries have more than one kind of process.

$b_{\text {Percent of }}$ kind of use - not percent of all catalytic hydrorefining.

$c<0.1$, 
ORNL-DWG $76-5273$

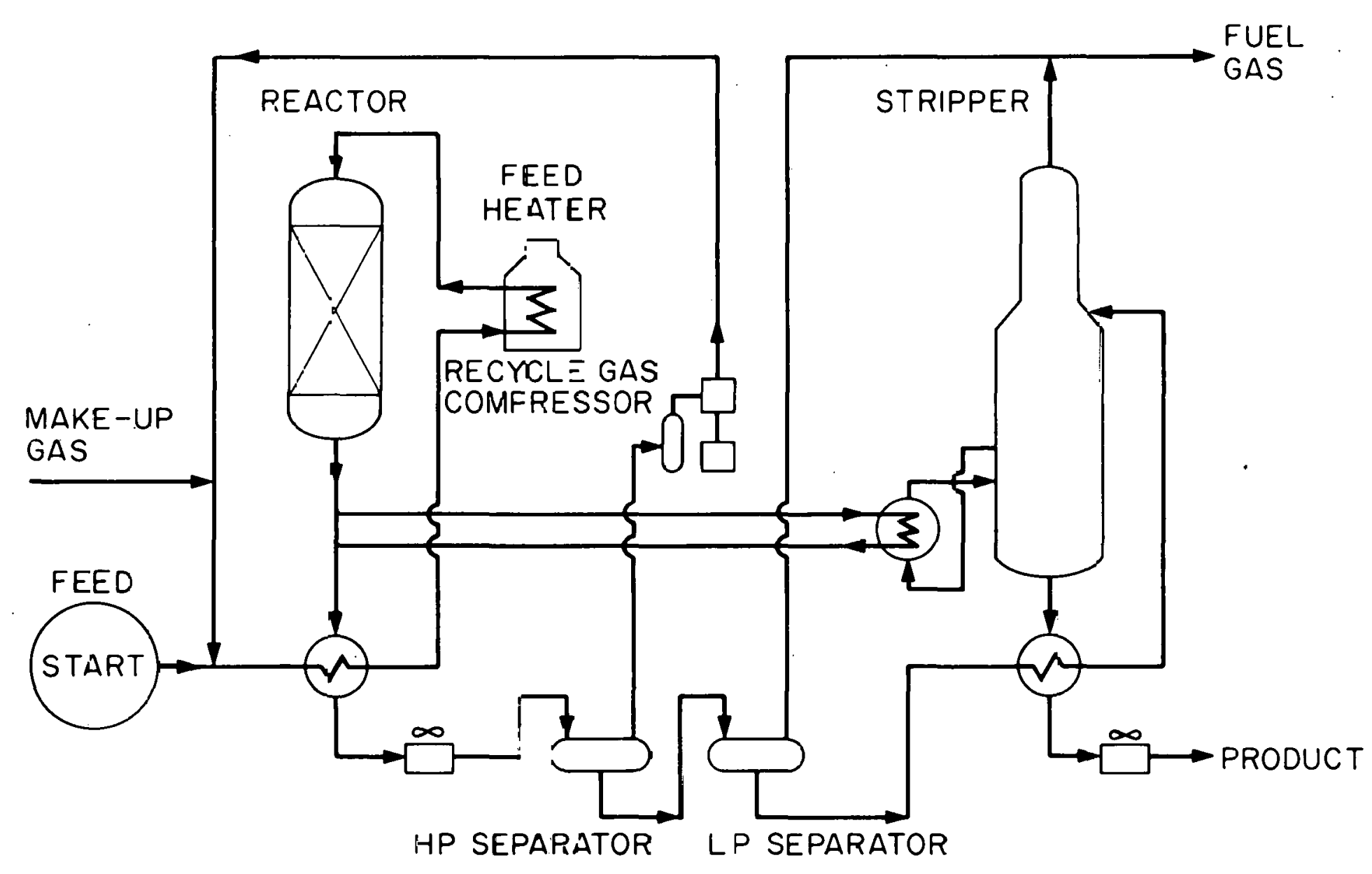

Fig. B.12. Catalytic-bydrorefining unit.

Source: 197@ Refining Process Handbook, Hz:drocarbon Processing, vol. 53 (9:, Gulf Publishing Company, Houston, Tex., September $=974$, p. 148 . 
capacity in Table B.7. Catalytic hydrotreating is used by $65 \%$ of the U. S. refineries (nearly all large refineries but only about $30 \%$ of the small refineries). Capacity is $30 \%$ of crude-oil capacity. The predominate use (about one-half) is for desulfurizing catalytic-reformer feed. Other uses are desulfurization of various products.

The many variations of catalytic-hydrotreating processes are very similar to each other and to the catalytic-hydrorefining processes. Generally the feeds are the lighter, lower- and middle-boiling components, and the main purpose is to desulfurize the feed. Over half of the hydrotreating capacity in the United States is for desulfurizing reformer feed and most of the remainder is used for desulfurizing various light refinery liquid products. The schematic diagram shown for catalytic hydrorefining is also applicable to catalytic hydrotreating; operating temperatures are somewhat lower $\left[175\right.$ to $430^{\circ} \mathrm{C}\left(347\right.$ to $\left.\left.806^{\circ} \mathrm{F}\right)\right]$ and pressures are in the lower part of the hydrorefining range ( $<600 \mathrm{psig})$. Hydrogen requirements, also generally less than requirements for hydrorefining, are 50 to $800 \mathrm{scf} / \mathrm{bbl}$ with an average of about $300 \mathrm{scf} / \mathrm{bbl}$. One process requires no supplemental hydrogen but has a gas-recycle rate of 2000 to $4000 \mathrm{scf} / \mathrm{bb1} .^{13}$

\section{Alkylation}

Alkylation is a petroleum-refining process in which an olefin is reacted with an isoparaffin, usually isobutane, to yield high-octane, branched-chain paraffinic hydrocarbons. Although alkylation can be achieved thermally, essentially all existing U. S. units use a catalyst either $\mathrm{H}_{2} \mathrm{SO}_{4}$ of $\mathrm{HF}$. Table B.8. shows the extent of these types of alkylation processes based on the 1974 survey data of ref. 1; five-eights of the units are of the $\mathrm{H}_{2} \mathrm{SO}_{4}$ type and three-eights are of the HF type. Alkylation is performed by $37 \%$ of U. S. refineries (nearly all of the 
Table B.7. Relative U.S. refinery use of catalytic hydrotreating

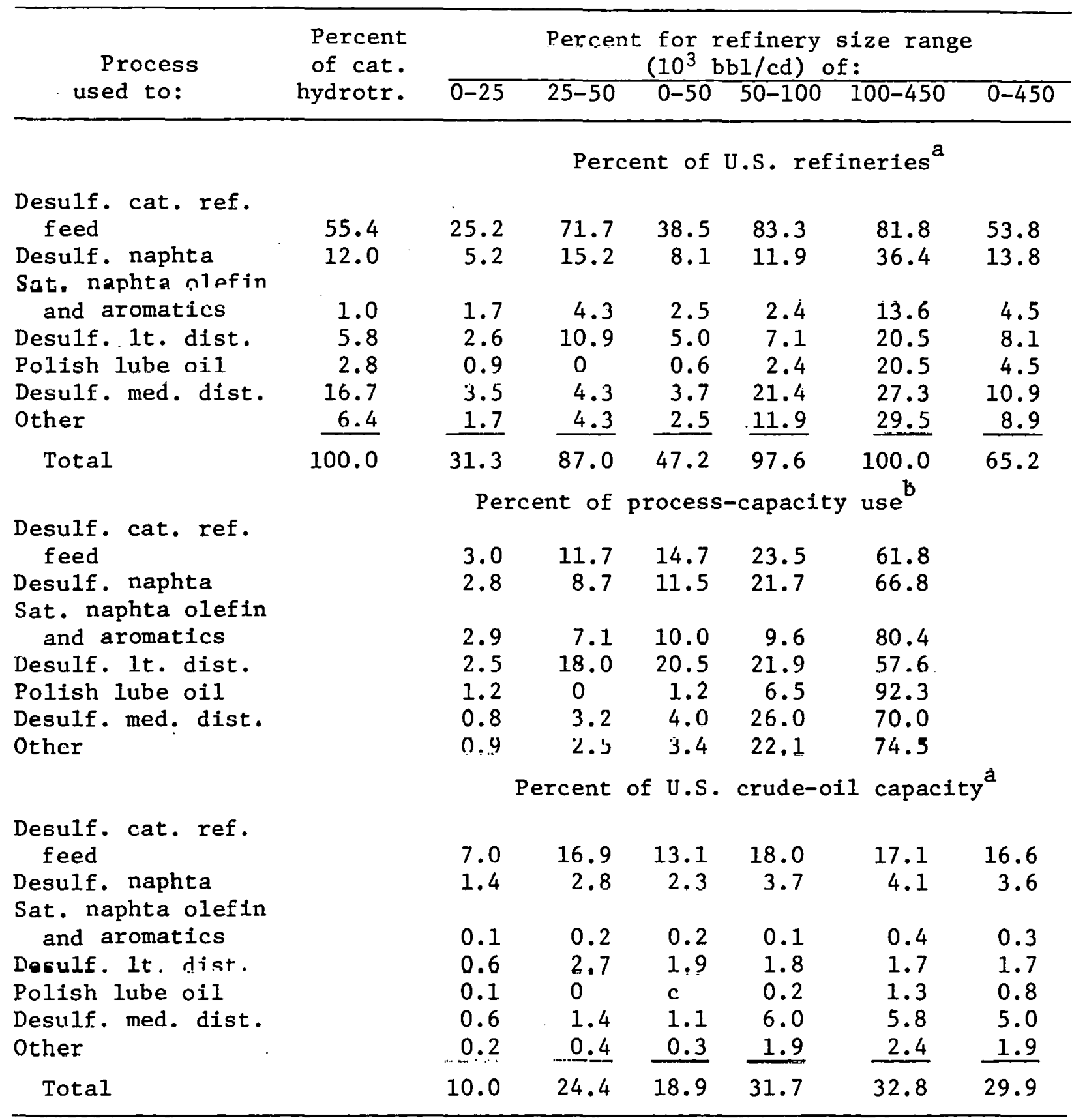

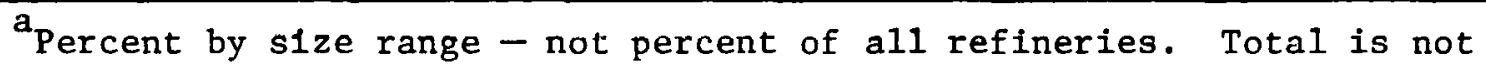
necessarily additive because some refineries have more than one kind of process.

${ }^{b}$ Percent of kind of use - not percent of all catalytic hydrotreating. $c<0.1$. 
Table B.8. Relative U.S. refinery use of alkylation processes

\begin{tabular}{|c|c|c|c|c|c|c|c|}
\hline \multirow{2}{*}{$\begin{array}{l}\text { Alkylation } \\
\text { process }\end{array}$} & \multirow{2}{*}{$\begin{array}{r}\text { Percent of } \\
\text { alkylation } \\
\text { processes }\end{array}$} & \multicolumn{6}{|c|}{$\begin{array}{l}\begin{array}{l}\text { Percent for refinery size range } \\
\left(10^{3} \mathrm{bbl} / \mathrm{cd}\right) \text { of: }\end{array}\end{array}$} \\
\hline & & $\overline{0-25}$ & $25-50$ & $0-50$ & $50-100$ & $100-450$ & $0-450$ \\
\hline & & \multicolumn{6}{|c|}{ Percent of U.S. refineries ${ }^{a}$} \\
\hline $\mathrm{H}_{2} \mathrm{SO}_{4}$ & 62.8 & 2.6 & 28.3 & 9.9 & 47.6 & 70.5 & 27.1 \\
\hline $\mathrm{HF}$ & $\underline{37.2}$ & 10.4 & $\underline{41.3}$ & 19.3 & $\underline{50.0}$ & $\underline{22.7}$ & $\underline{25.1}$ \\
\hline \multirow[t]{2}{*}{ Tota1 } & 100.0 & 13.0 & 69.6 & 29.2 & 95.2 & 90.9 & 36.8 \\
\hline & & \multicolumn{6}{|c|}{ Percent of alkylation-process capacity ${ }^{b}$} \\
\hline $\mathrm{H}_{2} \mathrm{SO}_{4}$ & & 0.7 & 6.9 & 7.6 & 19.2 & 73.2 & \\
\hline $\mathrm{IIF}$ & & 5.5 & 21.2 & 26.7 & 34.2 & .39 .1 & \\
\hline & & \multicolumn{6}{|c|}{ Percent of U.S. crude-oil capacity ${ }^{a}$} \\
\hline $\mathrm{H}_{2} \mathrm{SO}_{4}$ & & 0.3 & 2.0 & 1.4 & 3.0 & 4.1 & 3.4 \\
\hline $\mathrm{HF}$ & & 1.5 & 3.7 & 2.9 & 3.1 & 1.3 & 2.0 \\
\hline Tota1 & & 1.8 & 5.7 & 4.3 & 6.1 & 5.4 & 5.4 \\
\hline
\end{tabular}


large refineries but only $13 \%$ of the small refineries). The $\mathrm{H}_{2} \mathrm{SO}_{4}$ process is more common in large refineries and the $\mathrm{HF}$ process is more common in small refineries. Alkylation capacity is $5 \%$ of crude-oil capacity.

In thermal-catalytic alkylation processes feed is reacted at 52 to $232^{\circ} \mathrm{C}$ (125 to $450^{\circ} \mathrm{F}$ ) and 300 to 1000 psig pressure using a metal halide catalyst $\left(\mathrm{AlCl}_{3}\right)$; thermal alkylation processes require higher temperatures and pressures. The $\mathrm{H}_{2} \mathrm{SO}_{4}-$ and HF-catalyzed processes on the other hand, are very similar and operate at lower temperature and pressure -2 to $15^{\circ} \mathrm{C}$ (36 to $59^{\circ} \mathrm{F}$ ) and atmospheric pressure to $150 \mathrm{psig}$ for the $\mathrm{H}_{2} \mathrm{SO}_{4}$ process, and 15 to $50^{\circ} \mathrm{C}\left(59\right.$ to $\left.122^{\circ} \mathrm{F}\right)$ for the HF process. Removing heat from the reactions requires a refrigeration system for the $\mathrm{H}_{2} \mathrm{SO}_{4}$ units; HF units can use water cooling because they can operate at higher, lesscontrolled temperatures. HF is more readily recovered from the product than is $\mathrm{H}_{2} \mathrm{SO}_{4}$, but the $\mathrm{HF}$ units require somewhat higher temperatures in the HF stripper to break down the fluorides formed during the processing. The process choice of ten has been based on the economics of ac1d supply, recovery, and disposal.

For both acid-catalyzed processes the isobutane, olefin, and acid are fed to a reactor provided with a cooling system. The outlet stream from the reactor enters a settler tank (and caustic washer for the $\mathrm{H}_{2} \mathrm{SO}_{4}$ process) and then a fractionator(s) where isobutane is stripped for recirculation to the reactor and alkylate is separated from the butane and propane. Intimate contact of the acid catalyst with the hydrocarbons is provided by various means such as stirring or high-velocity circulation.

Figure B.13. shows schematic diagrams of $\mathrm{H}_{2} \mathrm{SO}_{4}-$ and $\mathrm{HF}$-alkylation units. A variation of the $\mathrm{H}_{2} \mathrm{SO}_{4}$-alkylation process is the autorefrigeration process where the refrigerant is mostly process isobutane 


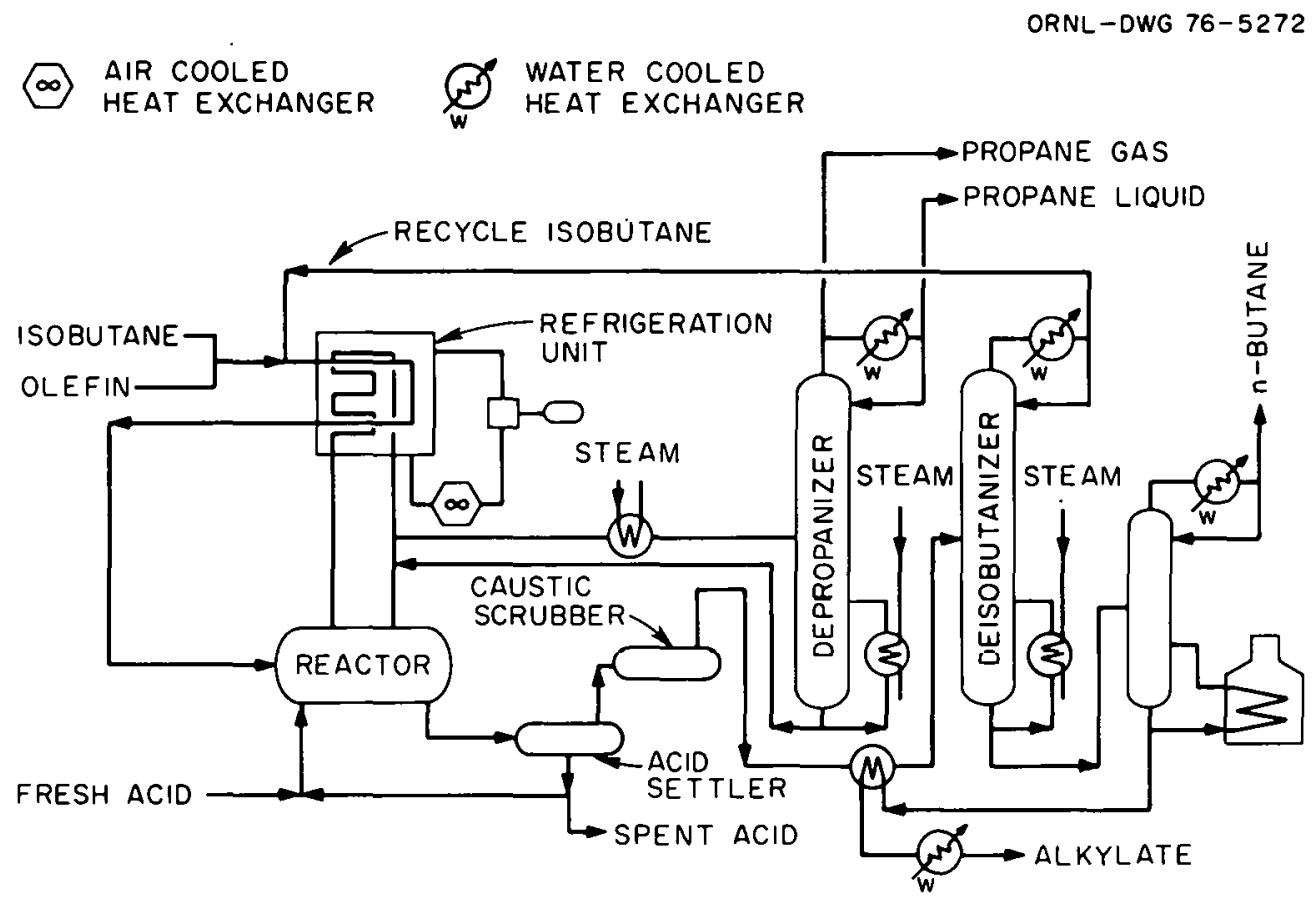

(a) $\mathrm{H}_{2} \mathrm{SO}_{4}$ ALKYLATION PROCESS

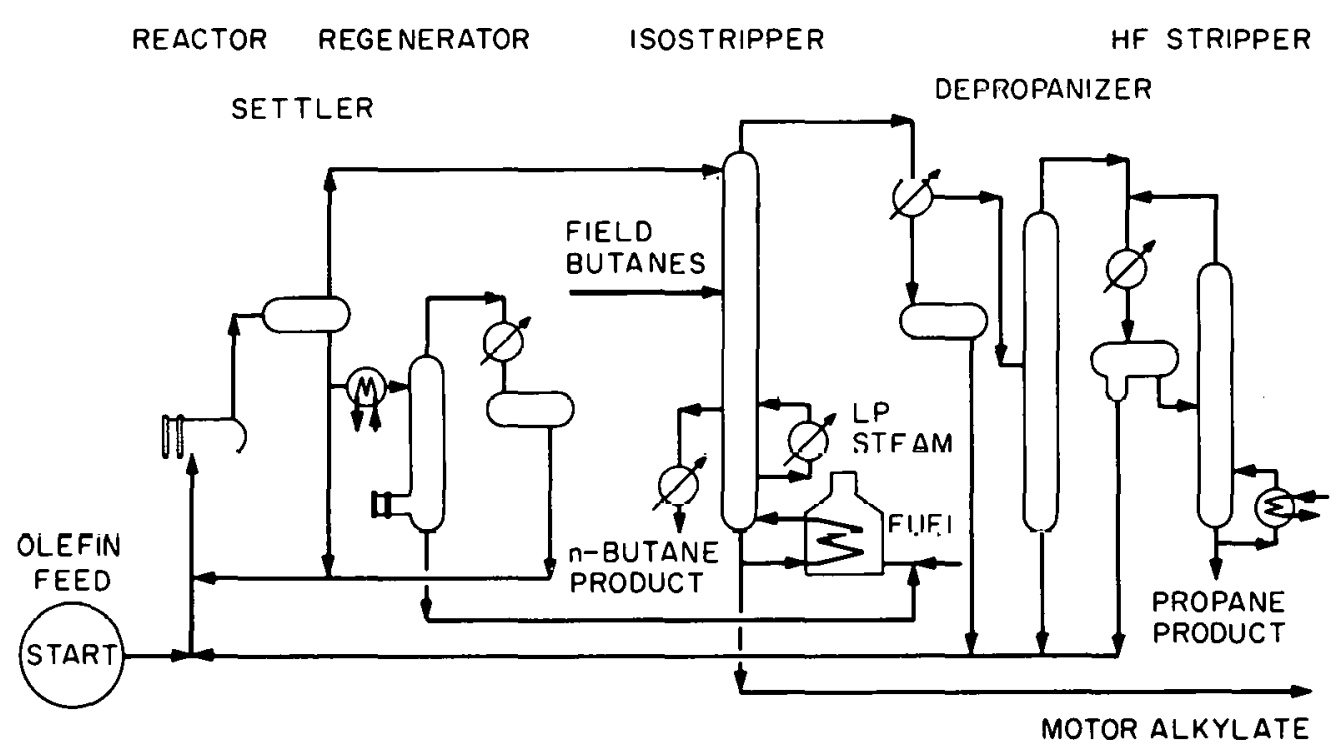

(b) HF ALKYLATION PROCESS

Fig. B.13. Sulfuric- and hydrofluoric-acld alkylation units.

Source (b): 1974 Refining Process Handbook, Hydrocarbon Processing, vol. 53 (9), Gu1f Publishing Company, Houston, Tex., September 1974, p. 208. 
with some propane content. Figure B.14. is a schematic diagram of the "cascade" type of reactor which requires much less isobutane recycle than the earlier "jet" type - about 2 recycle to 1 of product vs 5 -to-1. 18 The isobutane-to-olefin ratio in the reactor is about 25-to-1.

\section{Isomerization}

Isomerization is the process by which atoms of a hydrocarbon are rearranged without adding or removing material. It normally is used to form branched molecules from straight-chain molecules and tó increase the branching of molecules. One important use, $\mathrm{C}_{4}$ isomerization, converts normal butane to isobutane (a feed for alkylation units). $C_{5}$ and $C_{6}$ isomerization produces isoparaffins that can be blended into motor gasoline to improve the octane rating. Table B.9. shows the extent of isomerization capacity in the United States in $1974 .^{1}$ Isomerization processes are used by $11 \%$ of U. S. refineries; however, capacity is less than $1 \%$ of the crude-oil capacity.

The isomerization process consists of contacting the hydrocarbon with a catalyst under proper conditions of temperature and pressure. Aluminum chloride with hydrochloric acid or platinum-containing material are used as catalysts. Yield of branched paraffins is improved and side reactions are reduced at low reaction temperatures, but the reaction rate also is reduced as the temperature 1s lowered. Thus, the temperature chosen must be a trade-off berween these effecls in combination with use of side-reaction inhibitors. A common way to restrict side reactions is to carry out the reactions in the presence of hydrogen. Since little hydrogenation occurs the consumption of hydrogen is very low.

Operating conditions normally are in the same range for butane and pentane/hexane isomerization (i.e., 121 to $288^{\circ} \mathrm{C}\left(250\right.$ to $550^{\circ} \mathrm{F}$ ), 200 to 
ORNL-OWG $76-5271$

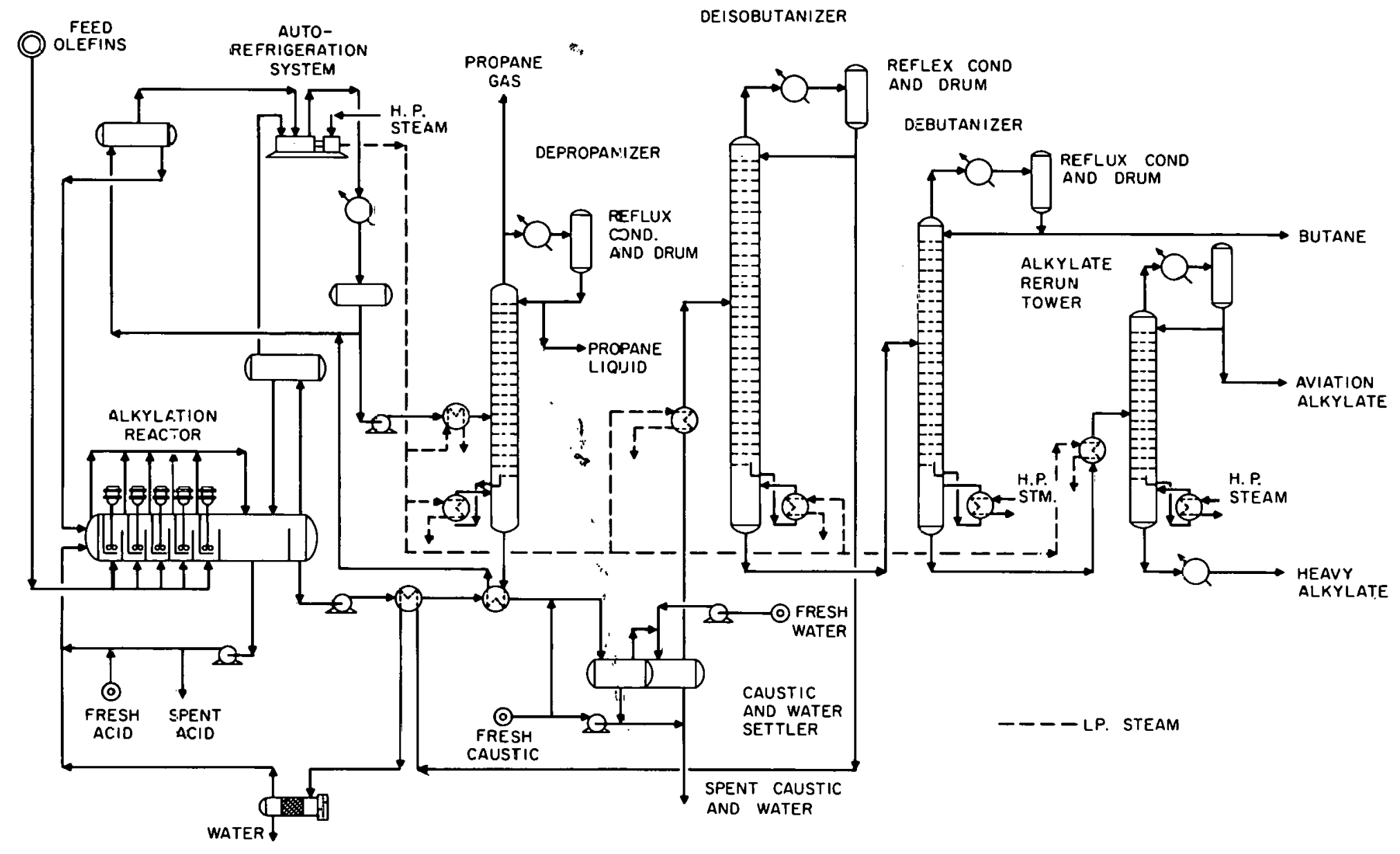

Fig. B.14. Cascade-type sulfuric-acid-alkylation unit incorporating an auto-refrigeration system.

Source: R. Stilles, The Alkulation Process, Petroleum Refiner, vol. 34 (2), Gulf Publishing Company, Houston, Tex., February 1955, p. =03. 
Table B.9. Relative use of isomerization processes

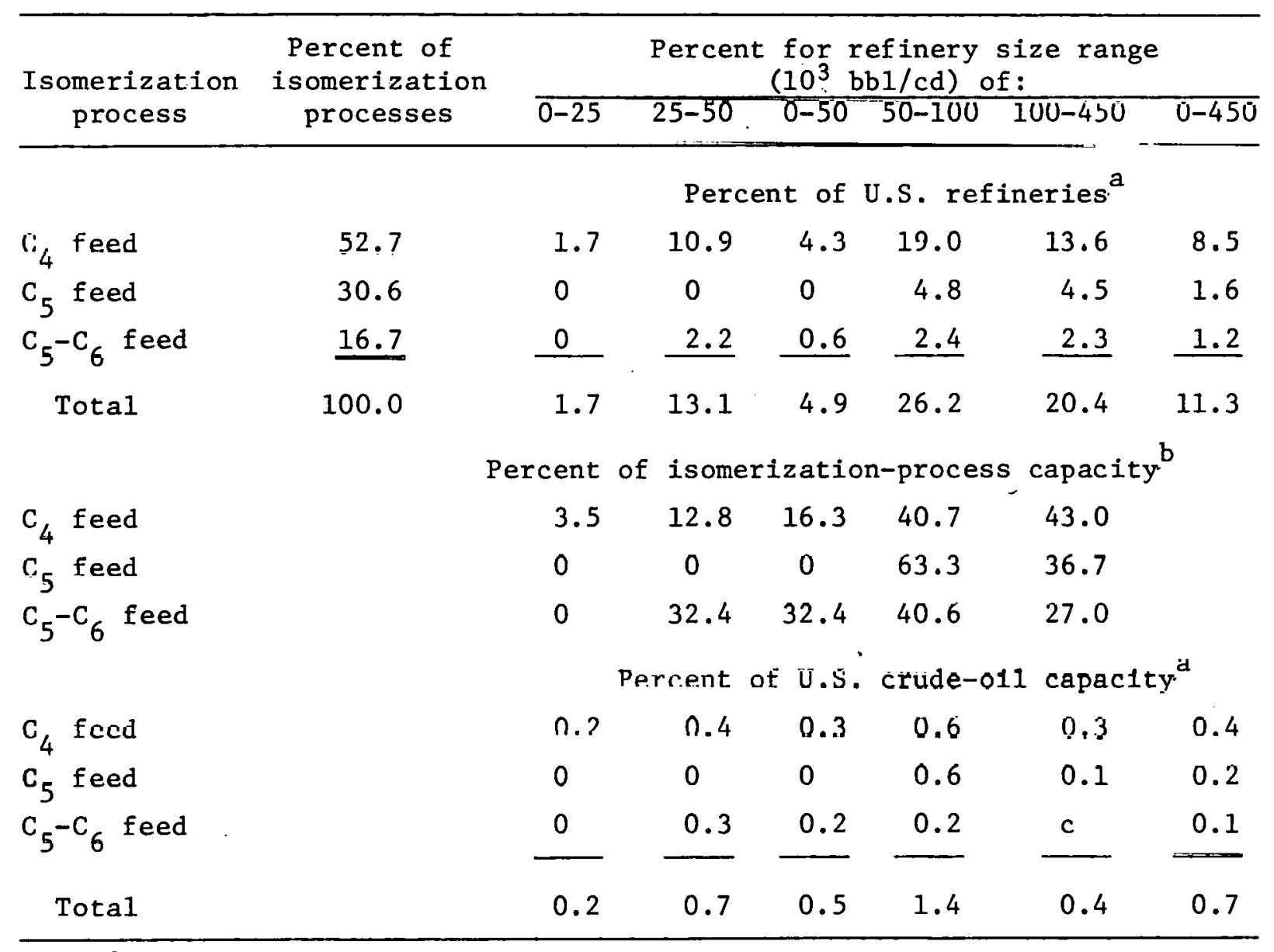

${ }^{a}$ Percent by size range - not percent of all refineries.

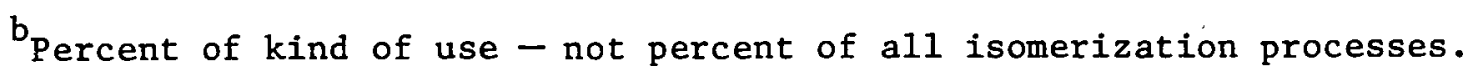

$c<0.1$. 
500 psig, and a hydrogen-to-oil mole ratio of 0.1 to $0.5: 1$ ) with butane isomerization tending to be performed in the lower portion of the ranges.

Figure B.15. shows schematic diagrams of isomerization units. Polymerization

Polymerization involves the conversion of olefin gases to liquid, higher-boiling hydrocarbons. Initially the conversion was carried out as a thermal process but was soon replaced by the more efficient catalytic-polymerization process. Catalysts are sulfuric acid, copper pyrophosphate, and phosphoric acid (the most widely used type). No survey information was found to indicate the extent of use of the polymerization process. However, because alkylation compared to polymerization produces more than twice as much gasoline per barrel of olefin and because the product is more compatible with modern engines, alkylation is the more popular route to upgrade gaseous stocks. ${ }^{19}$ Thus in this report polymerization is considered to be an insignificant user of energy.

A solid phosphoric-acid-catalyzed polymerization process is shown schematically in Fig. B.16. Temperature in the reactor is about $200^{\circ} \mathrm{C}$ $\left(392^{\circ} \mathrm{F}\right)$ and the pressure is from 400 to 1200 psig. The reactions are exothermic (670 Btu/lb of propylene and $400 \mathrm{Btu} / 1 \mathrm{~b}$ of butene converted), and thus quenching is required to control the temperature. Control is accomplished by introducing $\mathrm{C}_{3}$ recycle at several levels in the reactor vesse1.

\section{Hydrogen Production}

The need for a refinery to produce hydrogen depends on the extent the refinery practices reforming, thereby producing hydrogen, and hydrogen-consuming processes such as hydrocracking, hydrorefining, and hydrotreating. Refineries practicing an average amount of reforming 


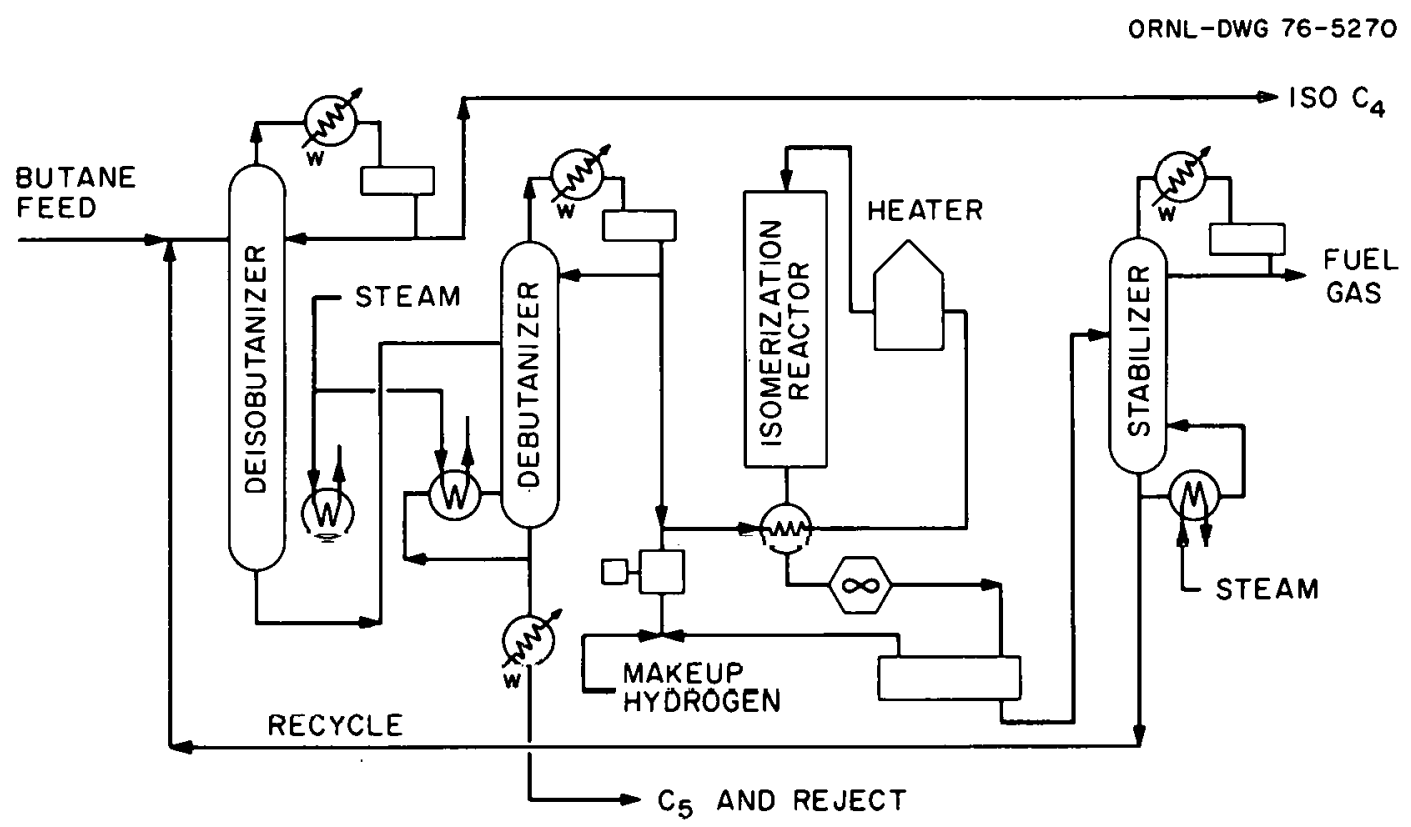

(a) BUTANE ISOMERIZATION UNIT

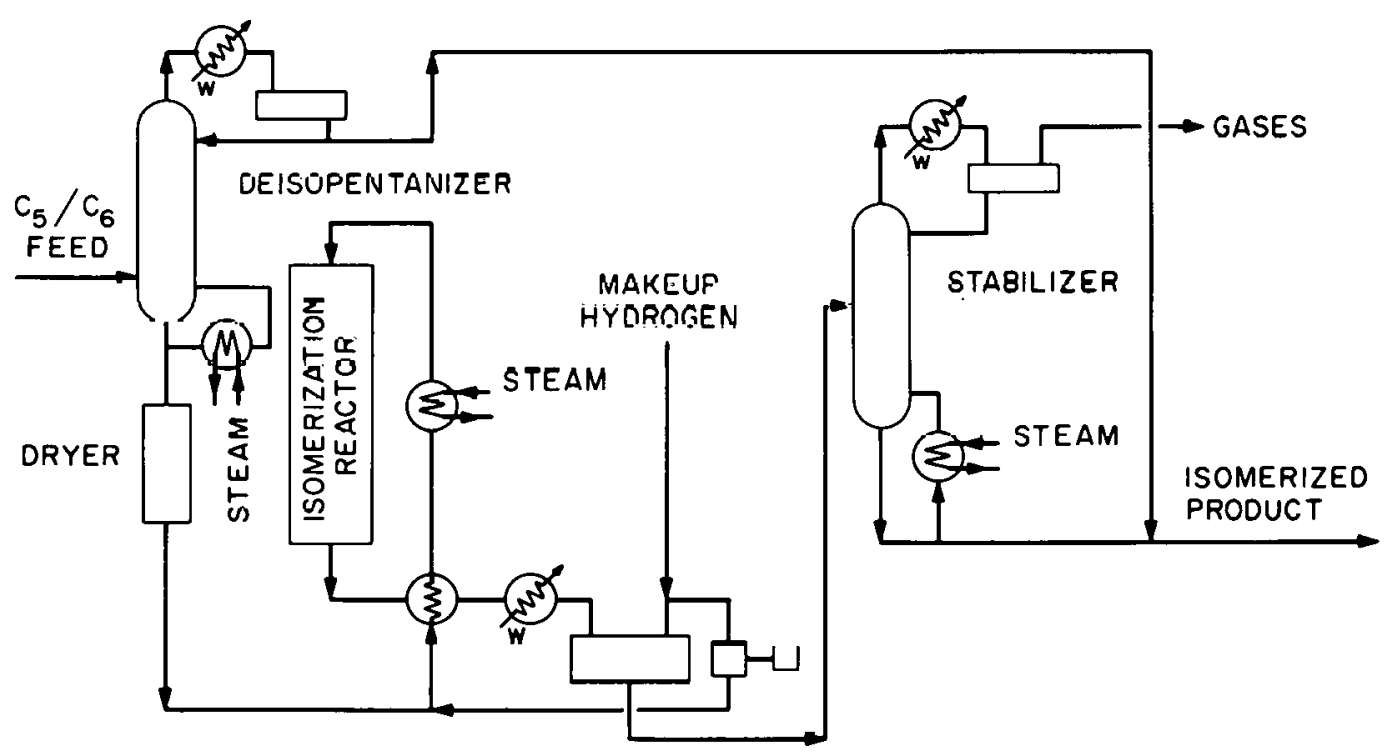

(b) PENTANE/HEXANE ISOMERIZATION UNIT

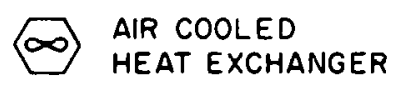

(3) WATER COOLED

PROCESS STREAM HEAT EXCHANGER

Fig. B.15. Butane and pentane/hexane isomerization units. 


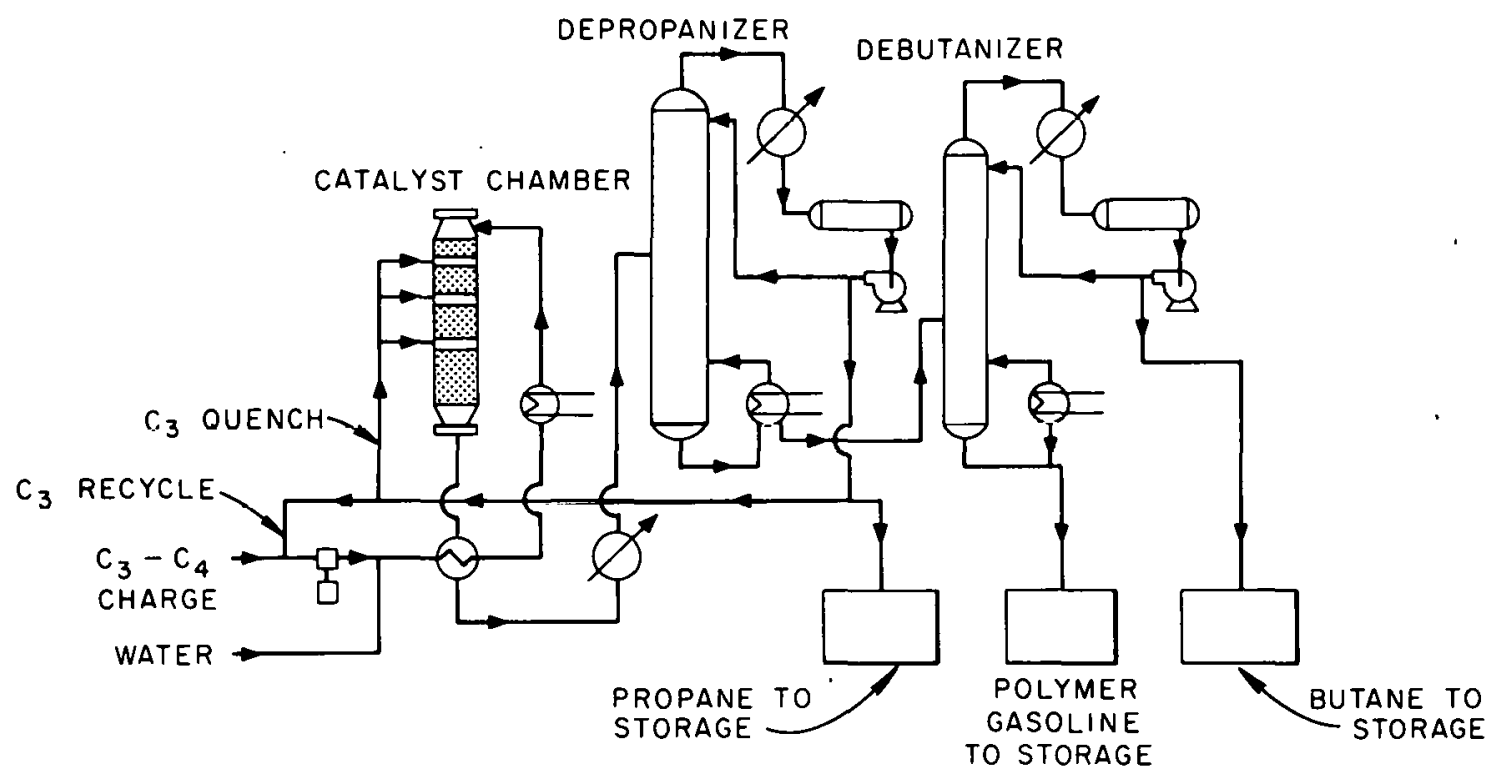

(a) SOLID PHOSPHORIC ACID CATALYST POLYMERIZATION PROCESS

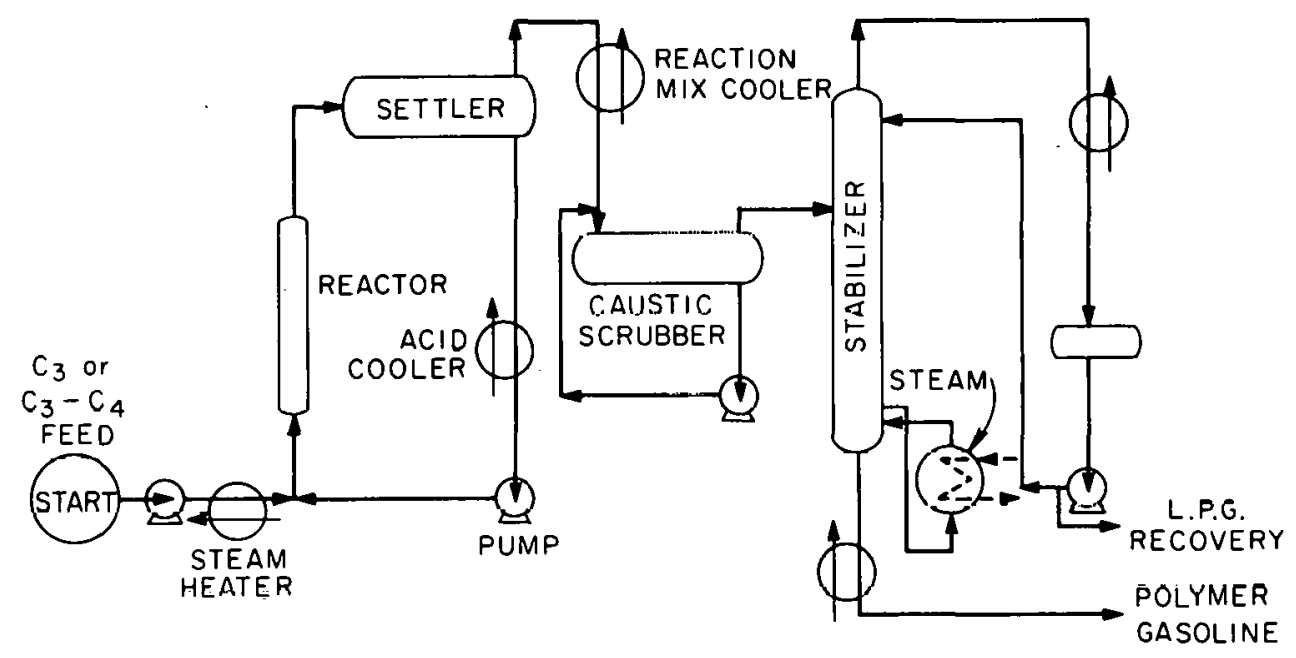

(b) LIQUIO PHOSPHORIC ACIO CATALYST POLYMERIZATION PRQCESS

Fig. B.16. Phosphoric-acid-catalyst polymerization units.

Sources ( $a$ ): G. D. Hobson, Moderm Petroleum Technology, 4th ed., John Wiley and Sons, New York, 1973, p. 360.

(b): 1966 Refining Process Handbook, Hydrocarbon Processing, vol. 45 (9), Gulf Publishing Company, Houston, Tex., September 1966, p. 211. 
probably produce enough hydrogen for their hydrotreating and hydrorefining units. However, if they also have a hydrocracker unit, they usually will require a hydrogen-production unit. Because no published survey gives the capacity of hydrogen-production units for U. S. refineries, an estimate was made based on the 1974 capacity $^{1}$ of the hydrogen-producing and hydrogen-consuming processes and on average hydrogen rates. * The estimate indicates a need to manufacture $600 \times 10^{6}$ scf of hydrogen per day; if this amount is assumed to be produced in the 32 refineries having a significant hydrocracking capacity, an average hydrogen-production unit is indicated to have a capacity of about $20 \times 10^{6} \mathrm{scf} /$ day.

Processes used to produce hydrogen are steam reforming of hydrocarbon gases and partial oxidation. Schematic diagrams of these processes are shown in Fig. B.17. Steam-reforming reactions are carried out in the presence of a nickel catalyst which is easily poisoned by contaminants such as sulfur. Thus the feed must be reasonably clean and often requires a purification unit. The reactions are endothermic $(97,300 \mathrm{Btu} / \mathrm{lb}$ mole for the steam reforming of methane). Typical operating conditions are $900^{\circ} \mathrm{C}\left(1650^{\circ} \mathrm{F}\right)$ and a steam-to-oil ratio of 3-to-1. The reaction results in a volume increase compatible with the need to use the hydrogen at high pressure, but the reacllun is favused by low pressure. For most units the pressure can be relatively high, up to 400 psig.

\footnotetext{
* A survey is being made by the $0 i 2$ and Gas Journal with a projected publishing date of April 1976.
} 


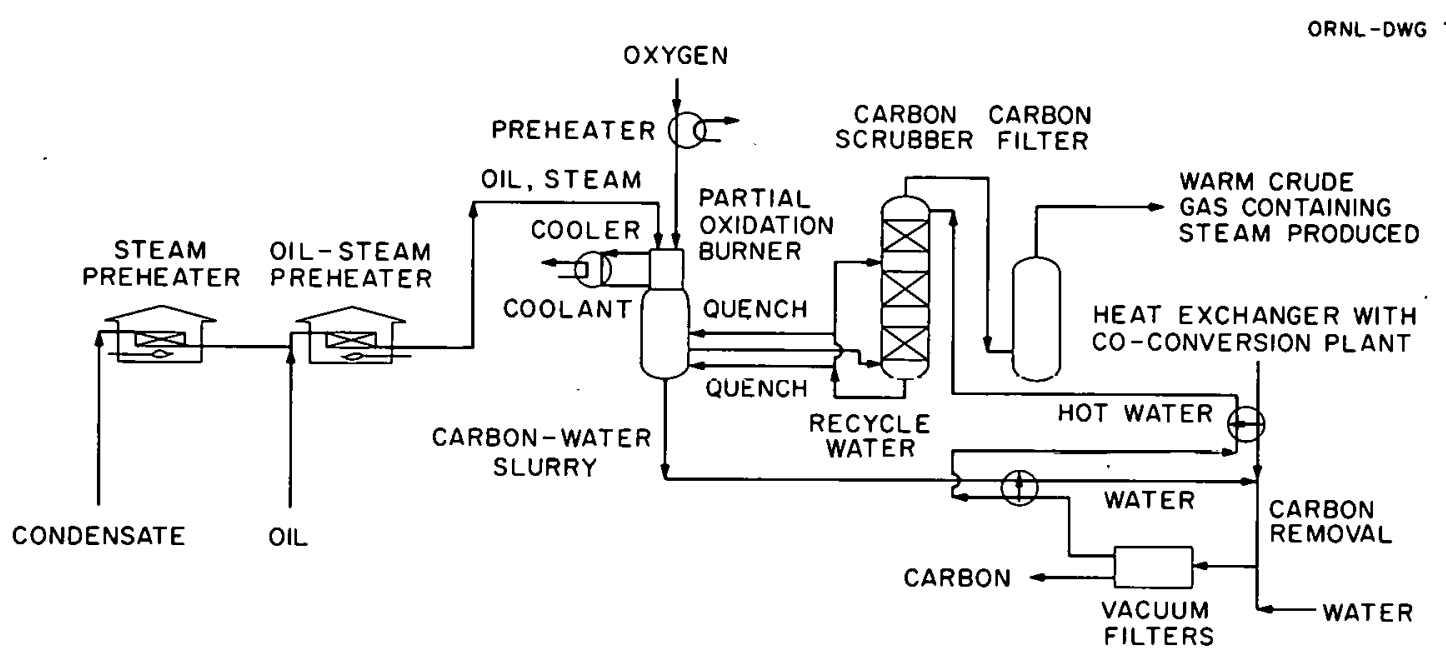

(a) PARTIAL OXIDATION PROCESS

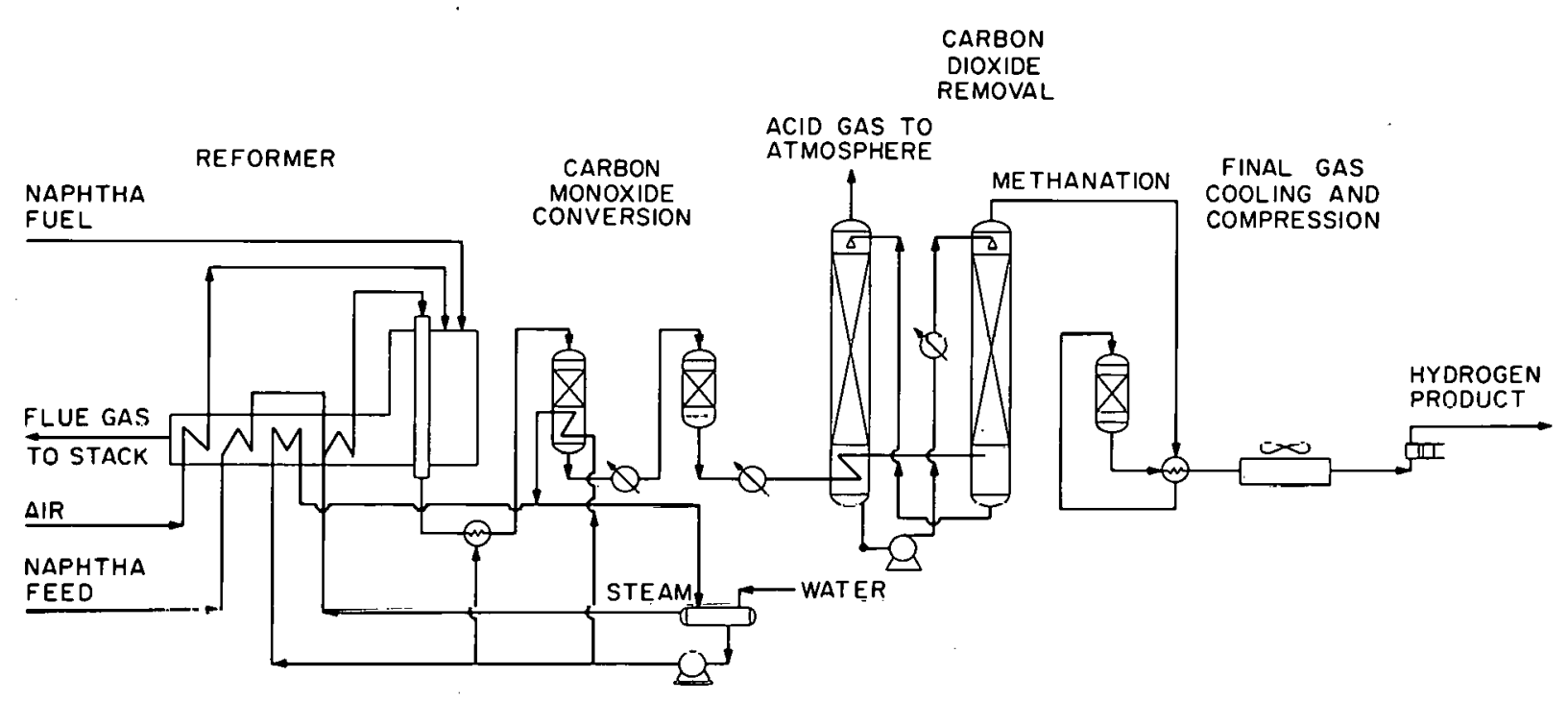

(b) STEAM REFORMING PROCESS

Fig. B.17. Hydrogen manufacturing processes.

Source: G. D. Hobson, Modern Petroleum Technology, 4th ed., John Wiley and Sons, New York, 1973, p. 324, 326. 
The partial oxidation process does not require a catalyst and thus feed purification to remove sulfur is not necessary. Feed, which can be any hydrocarbon from gas to fuel oil, is mixed with steam, heated, and then reacted with oxygen in a vessel where part of the feed is burned, producing a flame temperature of about $1450^{\circ} \mathrm{C}\left(2640^{\circ} \mathrm{F}\right)$. Unless a market exists for nitrogen, the size of the unit must be relatively large $\left(>10^{7}\right.$ scf hydrogen/day) to economically justify the cost of the oxygen. 


\section{INTERNAL DISTRIBUTION}

1. T. D. Anderson

2. S. I. Auerbach

3. S. E. Beall

4. D. J. Bjornstad

5. Doris Brooks

6. J. R. Buchanan

7. R. S. Carlsmith

8. W. S. Chern

9. 0. L. Culberson

10. F. L. Culler

11. J. G. Delene

12. A. P. Fraas

13. W. Fulkerson

14. G. S. Gill

15. W. R. Griffith

16. Miriam Guthrie

17. Nancy Hardin

18. V. O. Haynes

19. E. A. Hirst

20. S. I. Kaplan

21. R. S . Livingston

22. J. W. Michel

23. W. R. Mixon
24. J. C. Moyers

25. E. A. Nephew

26. H. Postma

27. S. A. Reed

28. M. W. Rosenthal

29. T. H. Row

30. I. Spiewak

31. R. L. Spore

32. E. G. Struxness

33. D. B. Trauger

34. G. U. Ulrikson

35. A. Zucker

36. Biology Division Laboratory

37-38. Central Research Library

39. Laboratory Records, ORNL R. C.

40-42. Laboratory Records Department

43. ORNL - Y-12 Technical Library

Document Reference Section

44. ORNL Patent Office

45. Institute for Energy Analysis

46. Research and Technical Support Division, ERDA-ORO

47-196. Energy Conservation Section

\section{EXTERNAL DISTRTBUTION}

197. D. C. Aze1l, Shell Oil Company, 1 Shell Plaza, P. O. Box.2463, Houston, Texas 77001.

198. R. B. James, Universal Oil Products Company, 20 UOP Plaza, Algonquin and Mt. Pruspect Roads, Des Pla1ns, I1l1no1s 60016.

199. J. H. Smithson, Office of Planning and Analysis, Energy Research and Development Administration, Washington, D.C. 20545.

200. J. F. Weinhold, Office of Planning and Analysis, Energy Research and Development Administration, Washington, D.C. 20545.

201. R. W. Wendes, Amoco Oil Company, 200 East Randolph Drive, Chicago, Illinois 60601.

202-475. Energy Conservation Distribution

476-502. Technical Information Center, ERDA, P. 0. Box 62, Oak Ridge, Tennessee 37830 . 